10.5.1 Schl 


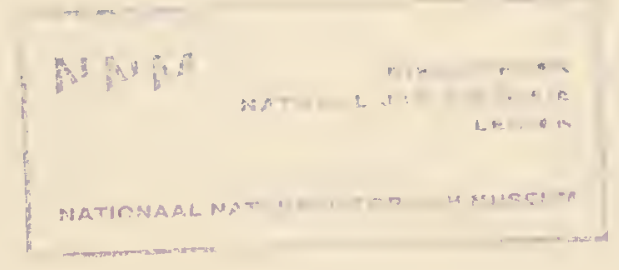

Borcocle: zie $\rightarrow$ puy. 1 
1633 




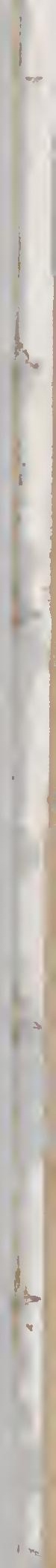




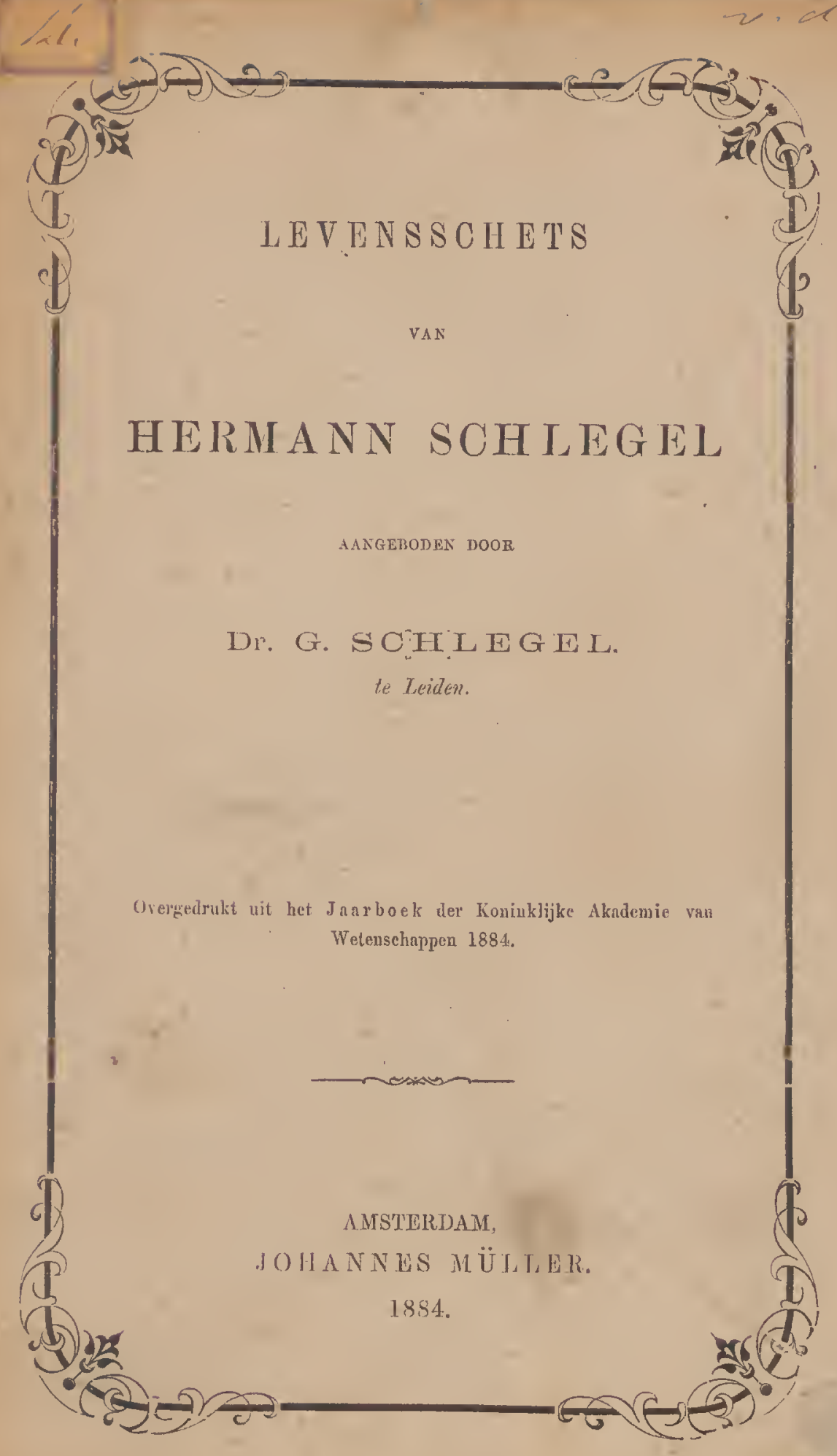


L E V E N S S C H E'T' S

VAN

\section{HER M A N S CHLEGEL。}

(Aangeboden door Dr. G. Schieger te Leiden).

"Dr. Hermand Schulger, Professor, Direktor des Königl. »Niederländischen Reichsmuseums für Naturgeschichte zu » Leyden, Ritter des Ordens des Niederländischen Löwen, »Mitglied der Königl. Akademien zu Amsterdam, Berlin sund Turin und vcrschiedencr anderer gelehrten Gesellschaf"ten, einer der berühmtesten Söhne unserer Stadt, ist am 17 »d. Mts. in Leyden hochbrjahrt zur ewigen Ruhe eingegangen."

Met deze woorlen begint een kort lcrensbericht van Schleger in de A Altenburge: Zeitung" van 23 Januari 1884, want in deze stad was het, dat hij den 10den Juni 1804 het levenslicht aanschouwde.

Zijn overgrootvader, uit de omstrelen van Worms afkomstig, stamde uit het oud en aanzienlij] geslacht der SculeGEL's, van 't welk een' lid reeds in 1323 door vorst BERNIARD van Anhalt beleend werd.

In het janr 1738 of 1739 trad hij in frauschen dienst, werd in den oorlog tusschen Frankrijk en Oostenrijk in 1740 door de Oostenrijkers krijgsgevangen gemaakt en maar Hongarije gebracht.

Daar werd hịj door den graaf BaTTHYANI, dic zelf meestal

\section{N'N! IN"}

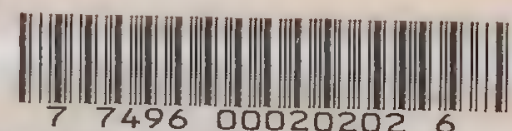

BIBLIOTHEEK 
in Weenen woonde, tot administrateur van één zijner goederen in Hongarịje aangesteld, welke plaats hem zóó goed beviel, dat hij, bij de later gevolgde uitwisseling van krijgsgevangenen, niet wenschte in aanmerking te komen. Graaf Batthyayi liet toen ten behoeve van zijn' administrateur eene school bouwen, waarvan ScHLEget meester werd, en bij welke gelegenheid hij hertrouwde met eene vrouw uit Stiermarken. Hij verwekte bij deze vrouw éen zoon, Melchior genaamd, (geb. 1746, $; 1805$ ), die geelgieter werd en zich te Praag vestigde. Wegens het lezen van een' bijbel, dien Metchior toevallig gevonden had, van ketterij besehuldigd, begaf hij zich naar Leipzig en van daar naar Altenburg, waar hij zich als geelgieter vestigde en door den Superintendent Reichlis in de Evangeliseh-Luthersche Gemeente werd opgenomen. Toen eehter in 1782 Keizer Frans van Oostenrijk zijn tolerantie-edict publiceerde, kreeg MrLchior Schlegrt het heimwee, en keerde naar Weenen terug met zijne vrouw en zijn toen 13-jarig zoontje (geb. 17 Oct 1769, de vader van Hermann Schueget). Niettegenstaande het tolerantie-edict, vond ScHLEGEI, daar echter zooveel intolerantie, dat hij reeds binnen veertien dagen Weenen verliet en naar Hermanstadt trok. Zijne vrouw bewoog hem echter naar Altenburg terug te keeren. Nadat zijn zoon, Johann David Schlegel, daar de burgersehool bezoeht had, dwong ziju vader hem tegen zijn' zin eveneens geelgieter te worden. In 1802 nam hij de zaak van zijn' vader over, en huwde den $19^{\text {den }}$ Juli 1803 met Johanra Rosina Skilek, uit wclk huwelijk elf kinderen geboren werden, waarvan HenMaNN de oudste was. Onder de leiding van David Schleger werd de geelgieterij eene bloeiende fabriek ${ }^{*}$ ), die toen voornamelijk de koperen ornamenten leverde, waarmede de Altenburger boeren gewoon zijn hunne paardetuigen te versieren.

-) De fabriek is thans in handen van een' zijner neven, levert pleeten en zilveren rijtuig- en tuigversierselen, wordt door stoom gedreven, en verschaft werk aan 300 arbeiders. 
Doch laten wij thans het woord aan Hermans zelven, in wiens nalatenschap ik eene door hem zelven in het Duitsch geschreven biographie vond, waarvan ik de Nederlandsche vertaling hieronder geef:

Mijne levensbeschrijving, die ik trouwens als lid der Academie niet ontgaan $\mathrm{kan}$, had ik gaarne aan anderen overgelaten, indien niet zooveel van mijne daden in vergetelheid begraven waren. Het is wel is waar een stuitend gevoel, zichzelven op den voorgrond te moeten plaatsen, of zelf toegezwaaiden lof te moeten verkondigeu, maar als ik het laatste gedaan lieb, is dit met geen ander doel dan den boozen te leeren, hoe de goeden over mij gedacht hebben.

Ik ben den $10^{\text {den } J u n i} 1804$ in Altenburg geboreu. Mijn vader had ecne zaak onder den naam van Fabriek van messing-gietwaren. Hij was een gemoedelijk, maar gestreng man, van oudduitsch »Schrot und Korn", van eene beproefde eerlijkheid, goede schoolvorming, net algemeene kundigheden toegerust, en die zich zijı geheele lange leven door met de meest verschillende wetenschappen beaig hield. Vrij van alle partijzucht, werd hịj herhaaldelijk tot scheidssechter gekozen; zelfs werd dikwijls zijn raad in de hoogste aangelegenheden gevraagd. Hij was eere-assessor bij het Vredegerecht, en werd in het jaar 1815 tot bevelhebber van den laudstorm benoemd. Zijne lievelingsstudiën wareu Philosophie, voornamelijk die van KAN', Entomologie en de fransche taal. Hij werkte vooral bezielend bij de stichting van wetenschappelijke vereenigingen, waarvan de leden gewoonlijk ten zijnent vergaderden; en toen de "Naturforschende Gesellschaft des Osterlandes" gesticht werd, nam hï het ambt van conservator der verzamelingen op zich.

Hij wịjdde zich met hart en ziel aan mijne oproeding, waarvan het systeem hoofdzakelijk gebaseerd was op dat, hetwelk FlredertK Willem I van Pruisen voor zijn' zoon Frederik den IIen outworpen had. De mildste bepalingen daarvan waren: het geheele jaar door op slag van 5 uur 
des morgens vereeniging aan de studeertafel. Des avonds 10 unr ophouden met allen hoofdarbeid; vlijt, ernst en stiptheid in alle berighcden: voortreffelij]ke regels, bij mịj tot gewonte geworken, en die ik nog tot op den huidigen dag oprolg.

De strengere bepalingen waren samengevat in de grondbeginselen van eene blinde gehoorzaamheid, volkomene onderdanigheid en onvermurwbare gestrengheid. Aan den anderen kant stond mịnn vader mij, zoovesl hij vermocht, leerzaam ter zijjde; maakte mij op alles opmerkzaam; zette mij voortdurend tot nadenken aan, en wịjdde mịj in vele zaken in, die een' knaap anders rreemd blijven. Het dualisme zijner beginselen moest echter noodzakelijk tot twee tegenovergestelde richtingen leiden: de eene verwijderend, zooals het geval was met bovengenoemd vorstenpanr, de andere toenaderend en in de hoogste mate vormend, zooals plaats greep tusschen MozanT en zijjn' vader. 'Zonder dezen invloed zoude veel zich klaarblijkelijk anders toegedragen hebbeu.

Onder de toenmalige jeugd mijner vaderstad, alsook bij vele oudere lieden, zelfs in den burgerstand, bestond eene wuitengewone liefhebberij voor de natuurwetenschappen. Het verzamelen van dieren, vooral van kapellen, van vogeleieren, ook van planten en steenen, was zeer algemeen. Ferste punt van aantrekkelijkheid was de kapellenverzameling van mijn' vader, en dit zelfs reeds in de vroegste kinderjeugd. De Leine, een omvangrijk boseh in den omtrek, dat heden nog, wegens de zuidelijke tint zịjner fauna, het Eldorado der Leipziger kapellenjagers is, leverde rijk materiaal op. De lust tot verzamelen had ook eenige ferme werklicden van ons huis bekropen, en deze vergezelden mij op mijue uitstapjes. Dientengevolge kon alles degelijk, systematisch en in het groot gedraven worden. Het opkweeken van rupsen werd weldra hoofdzak. Lange staken met haken, reusachtige lakens om onder de boomen te leggen, verscliaften ons overvloedig al wat op de boomen leefde; struikgewas en planten werden afgezocht, de schors der boomen afgevild, 
de aarde tusschen de boomwortels doorwoeld, en al het gevondene ter waarneming en opkweeking in een bijzonder vertrek verdeeld. Daarbij kwamen nog allerlei uit den vreemde toegestunrde iusecteneieren. Dit bracht mij van zelf tot de studie der overige insecten, alsook tot die van andere dieren en planten, maar hoofdzakelijk tot herhaalde proeven om basterdsoorten te teelen, de grootst mogelijke hoeveclheid variëteiten te verkrijgen of het gehein van afwïkende vormen te hespieden, b. $\nabla$. de twee vormen van Vanessa (Araschnia), $V$. levana en $V$. prorsa genaamd.

De verschijning van eenige aan de streek vreemde, zeer zeldzame soorten, leidde mijne aandacht op de migraties van dieren of hunneoverberolking. Dartoe behoorde voornamelijk de zeer zeldzaan voorkomende rups van Sphinx (Chairocampa) celerio; de, gedurende ecn enkel jaar, in de orangerieën van den Hertog van Saksen overal tegelijkertijd, en in betrekkelijk groot aantal, gevonden rupsen van Sphinx (Daphnis) nerii, en het in zeker jaar plotseling versehijnen van groote massa's vall de anders zoo zeldzame Bombyx (Spatalia) bicolora.

Het zich vertoonen in het Gothasche van eene, hoewel kleine, kolonie $\operatorname{van}$ eene zwarte veldrot, die men anders slechts in vele streken van Zuid-Rusland vindt, scheen mij toe eene vingerwijzing tot het bestaan van bijsoorten te zijn.

Maar vooral was het de betrekking der rupsen tot de planten, van de levende wezens in het algemeen tot elkander en tot het klimaat, de ligging en hoedanigheid der plaats waar zij gevouden worden, die het nitgangspunt vormden van mijne nasporingen omtrent de wetten der geographische verspreiding der dieren en der planten, hunner grondrormen met betrekking tot hun samenstel, kortom naar de gezamenlijke oorzaken van elk afzonderlijk verschijnsel.

Dit alles legde, reeds in vroeger jaren, de kiem tot de beschouwingen en die richting, welke ik in al mijne werken heb gevolgd.

De toevallige vondst van een buizerdnest met eieren, en 
de $2^{\text {editie }}$ van Bechstern's Naturgeschichte Deutschlands, die mijn vader mij ten geschenke gaf, leidde mijne aandacht op de studie der ornithologie. Ik leerde vogelhuiden praepareeren, en trachtte, ten einde tijd uit te winuen, deze kunst tot de eenvoudigste regelen terug te brengen. Eene vogelverzameling werd aangelegd, levende vogels, voornamelijk roofvogels, gehouden, waaronder niet alleen de Edelvalk, Havik en Nachtuil, maar ook de Torenvalk en de Buizerd, en zelfs deed ik proeven met valkenafrichting.

Behalve bovengenoemd bosch, de Leine, verschaften mij de omstreken van de stad Schmöllu, waarheen ik mij gęwoonlijk gedurende de feestdagen en schoolvacanties begaf, eene tweede hoofdplaats voor mijne verzamelingen en nasporingen. Deze stad ligt eenige uren van Altenburg, nabij het gebergte. Mijn grootvader van moeders zijde, die daar woonde, was landhuishoudkundige, en liet mij naar hartelust op de weilanden en velden en in het bosch ronddwalen. Tk beschouwde mï daar vrijer dan een vorst, en als ik er met eene ossenkar heenreed, meende ik meer te zijn dan die oude frankische koningen, die eveneens zoo reden, omdat ik bovendien een gelukkig mensch was.

De aldaar gevestigde houtrester Grotifer, een man in de school van Bechsteis gevormd, nam mij als scholier onder zijne hoede mede. Hij leerde mij de edele jacht naar alle regelen der kunst. Eerst nadat ik geleerd had eekhorentjes, konijnen en hazen met de kogelbuks zeker te treften, mocht ik een met hagel geladen geweer dragen. Hij verstond de kunst van vogels te praepareeren groudig, en was een ongemeen geoefend schutter. Veel aantrekkelijkheid in die plaats had ook voor mij een glasblazer, die wel is waar zijn handwerk met talent uitoefende, maar alléén om daarmede den kost te verdienen. Ziju geheel bestaan giug eigenlijk in twee dingen op: rogelvangst en jacht op gruot wild. Zijn huisje lag buiten de stad, aan de glooiing van eene terrasvormige hoogte. Daar berouden zich alle denkbare gereedschappen tot de vogelvangst. In het bosch had hij 
met goedkeuring van den houtvester, zoutlikplaatsen voor het groot wild aangelegd, en in de buurt daarran op oude eikeboomen zoogenaamde kansels geplaatst, van waaruit men de groote dieren, in de stilte van den nacht en onder den overweldigenden indruk eener grootsche en eenzame natuur, waarnemen kon.

Als er een hert geschoten was, hetgeen echter niet dikwijls gebeurde, werd het in triumf door de stad gedragen, en de vreugde bereikte haar toppunt, toen eens de bloedhonden eene jonge hinde opgejaagd hadden, en deze levend naar het park van den baron voк Tнüммет in Altenburg gebracht werd, waar zij later tot een' rijzigen twaalfeinder opgroeide.

Deze glasblazer was voor het overige een fijn waarnemer; hij ging nooit zonder geweer uit, en, als zijn getrouwe metgezel, leerde ik van hem zeer veel omtrent de zeden en de leefwijze der vogels en andere dieren. Maar de hoofdrol bij het verzamelen en de onderzoekingen in de omstreken van Schmölln, speelden twee knapen: KASPAR en Georg. Ik had ze, zelf bijna nog een kind, tot mij getrokken, en den jongen KASPAR, als den beter ontwikkelde, voor de grap tot mijn' lijfjager benocmd. Zij waren de zoons van een' armen wever, liepen blootsvoets, waren sterk, geoefend in het loopen en klimmen, hartstochtelijke vogel-, visch- en kreefteuvangers, en ten allen tijde gereed om alles te doen wat ik wenschte. Van te voren gewaarschuwd wanneer ik naar Schmölln kwam, stonden zij bij mïne aankomst, met groote stokken gewapend, voor de deur van mijn grootvaders huis, om met mij naar buiten te trekken, hetgeen ook geregeld onmiddellijk gebeurde. Zoo lang ik in Schmölln bleef, verlieten zij mij alleen om thuis te slapen. Allerlei voorwerpen van natuurlijke historie werden dan verzameld, en als ik wegging, droeg ik hun op daarmede voort te gaan, en zelfs om zekere waarnemingen te doen.

Op deze wijze slaagde ik er o. a. in, studiën over de voortplanting van den koekoek te maken, en de leefwijze 
van den zeer zeldzaam voorkomenden en verborgen levenden wespvalk (Pernis apivorus) nauwkeurig te leeren kenuen; de plaats, die hij toen onder de buizerden vrij algemeen innam, heeft inij altijd zeer precair toegeschenen. De Naturforschende Gesellschaft des Osterlandes vertrouwde mij weldra de zorg voor hare verzameling van hoogere dieren toe; ik kon in hare bibliotheek mïne boekenkennis vermeerderen, terwijl menige betrekking tot geleerde en degelijke lieden werd aangeknoopt.

De wensch, grootere verzamelingen en een' meester in het vak te zien, bracht mij naar Renthendorf bij den predikant BrEm, toen met NAUMANN de grootste ornitholoog van Duitschland. Mijn eerste bezoek bracht ik hem toen ik nog geen dertien jaar oud was. Deze geestige en eigenaardige man behield mij gedurende de schoolvacantie bij zich. Hij dwaalde dagelijks door bosch en veld, en het deed hem veel genoegen te bemerken, dat ik vlucht en stem der vogels zoo goed kende. Ik had hem mijne warnemingen schriftelijk medegedeeld, en ik was er niet weinig trotsch op, dat hem verschillende feiteu, die hij ook later in zijne werken opnam, toen nog nieuw waren. Daartoe behoorde onder anderen het broedsel van den kleinen roerdomp (Ardea minuta), waarvan ik het nest en de eieren gevonden had, als ook de ontdekking van den moerasrietzanger (Calamodyta palustris), welke Brenu zelfs toen nog loochende, toen ik hem op een', in de onmiddellijke nabijheid zijner woning staand elzenboschje, zingeuden vogel dezer soort had opmerkzaam gemaakt, welken vogel hij echter voor eeu', zoonls hij zich uitdrukte, knoeienden en nog niet volleerden spotvogel (Hypolais) hield.

Ik weuschte de zaak echter tot klaarheid te brengen, en daar het reeds begon te schemeren, beloofde ik hem den volgenden morgen den zanger te schieten, terwịl de dominé kerk hield.

De preek was nog niet geheel ten einde, toen ik door de oper kerkdeur, met ınju' vogel in de hand verborgen, binnentrad. 
Een wenk gaf den meester het slagen mijner jacht te kennen. Hij had zijne kleine gemeente de almacht Gods in de wonderen der natnur geschetst; maar met eene behendige wending sloot hij zijne rede met eene nitnoodiging om de bewijzen zijner preek in zijne verzameling te komen beschonwen, waarbij hij zijne toeschouwers op koffie en koek trakteerde. Hij was, de kerk uitgaande, vooruitgegaan en ik liep naast hem met het geweer over den schouder.

In zijne studeerkamer binnengetreden, wierp hij zijne toga af, bekeek den vogel nauwkenrig en riep uit: 》Gij hebt »gelijk, ik heb die soort nooit geschoten en bezit ze niet in » mijue verzameling. Kom in mijne armen; in $U$ zit een »eclite naturalist."

Deze gebeurtenis was voor mij van des te meer gewicht, omdat ik reels toen vermoedde, dat de stndie der rietzangers, zooals ik ook later zal aantooneu, tot een juist inzicht van het begrip soort, alsook tot de erkenning van de verwantschap en afwijkingen der soorten van een' diervorm leiden moest.

Een dergelijk voorval als met dien » verwenschten" rietzanger, zooals BrвHм hem in scherts noemde, beleefle ik later voor de poorten der stad Leiden met Joy. NAT1ERER, een van de knndigste ornitholugen van zijn' tijd, dien ik echter niet overtuigen kon. Terloops zij nog opgemerkt, dat de jacht op dezen vogel slechts weinigen gelnkt, omdat zij, wil men slagen, evenals die op den korhaan moet uitgeoefend worden.

De aantrekkingskracht, die de geheele kring der natuurlijke geschiedenis op mij uitoefende, werd ondertusschen reeds vroeg naar een gemeenschappelijk middelpnnt geleid.

De aanleiding daartoe was de Allgemeine Geschichte der Reisen", die mijn vader mij schonk. Dit boek bleef standvastig bij mij, en een onwederstaanbare lnst vreemde landen, ja de geheele aarde, te bereizen, maakte zich van mij meester. Ik hield de zaak streng in het oog en kwam weldra tot de overtuiging, dat de vergelijkende physische Geogra- 
phie, in haar volsten omvang, de sleutel van alle natiuronderzoek was. De studie der laatste werd vroeg opgewekt door het regelmatig bezoek aau de Leipziger Messe, als ook door de oorlogen van Napoleon Op deze wereldmarkt kon men, zooals bekend is, allerlei volken van Europa, tot de uiterste grenzen van Rusland, ja zelfs van westelijk Azië, leeren kennen. De oorlogen van Napoleon maakten dit tooneel volledig. Zijne legers brachten de volkeren van het Westelijk en Zuidwestelijk Furopa tot ons, en van den anderen kant kwainen zij uit het Oosten en Noordoosten van ons werelddeel. Vooral trokken de Lappen, Kozakken en Baschkiren het meest mijne aaudacht. De totaalindruk, dien deze in massa waargenomen vreemde volken op mij maakte, was onvergaukelijk. De Kozakken, die men toen nog als een' Mongoolschen stam beschouwde, bleken fraaie manuen van Zuid-Europeesch ras te zijn, die er niet aan dachten den knaap kwaad te doen, maar hem integendeel op hunne paarden lieten rossen, en bij het afscheid altijd aangedaan waren. Nog meer waren wịj over de Baschkiren verwonderd, die men eveneens als monsterachtig geschilderd had. Hoewel dikwijls ruw van gelaatstrekkeu, waren er toch verscheidene fraaie manuen onder, zoodat zelfs een vau hen, een stevige »veertiger", de Aartsvader genoemd werd.

Was het toe te schrịjven aan mịnne jeugd, of aan de onbeschroomdheid, waarmede ik met deze natuurmenschen kennis aanknoopte, of bracht ik hun hun eigen kinderen in hun vergelegen vaderland te binnen? Kortom, ik werd weldra hun lieveling; zij toonden mij hunne wapens, vooral het gebruik van hun boog en pijl, die zij tot eene onbegrịppelijke hoogte wisten in de lucht te schieten. Ook hun viel het afscheid zwaar, zij weenden als kinderen, en ik zag ze met leedwezen wegtrekken, omdat ik ze in hunnen waren aard en niet als ruwe soldaten had leeren kennen.

In zulke bewogen tijden leeft de mensch in een' staat van voortdurende opwinding. Een dag bracht meer nieuws en verscheidenheid dan anders maanden het doen, en het 
kleine jachtgeweer, waarmede ik van jongs af vertrouwd was, werd voor een klein soldatengeweer verruild, dat ik als adjudant van miju' vader droeg. Het liefst bleven wij achter de ligne de bataille, hielpen de gewonden verbinden, en verkreeg ik spuedig eene noodzakelijke zelfstandigheid in het handelen, een dieper inzicht en eene ernstige, zedelijke vroegrijpheid. Onder de toenmalige jeugd was ook eene zekere vrijgeesterij ell een opstand tegen het oude gebruikelijke ontstaan: verschijnselen, die als voor den staat gevaarlijk werden beschouwd. Dit was ook het geval met de leerlingen in de kostschool van WINkLER, waartoe ik eveneens behoorde. Onder de toen reeds vertrokken leerlingen, bevonden zich de latere Kerkeraad HAsE en de wetenschappelijke kunstenaar ERNst FöRsTER. Niemand had een zoo aangenaam voorkomen als HASE; er bestond geen gezelliger metgezel, en niemand hanteerde den degen zoo goed en zoo sierlijk als hij Hij maakte in de stad, hetgeen de Franschen »la pluie et le beau temps" noemen, en werd door de jeugd als eene autoriteit beschouwd. Tot Förster voelde ik mij aangetrokken door zijn buitengewoon talent in het teekenen, te meer nog daar ook ik door zijn' leermeester en onzen huisvriend, Professor Schmid, opgeleid werd.

Mijn vader wijdde, als een verlicht voorvechter der vrijheid van gedachte, eene zeer bijzondere aaudacht aan de godsdienstige woelingen van dien tijd. Het werk van DuPUIs 》Origine de tous les cultes" en van Volvex 》lues Ruines" had wortel geschoten. Iedereen vormde zijne eigene denkwijze; ik eveneens, en hoe jong ook, duldde ik geene tegenspraak. De methode $\operatorname{van}$ catechisatie-onderricht in onze school beantwoordde in geenen deele aan de eischen des tijdgeests. De leeraar, een man van wien ik trouwens veel hield, had eene zoetsappige, gezalfde voordracht, en sprak het liefst over de openbaring van Johannes. In den speeltijd werd het behandelde besproken, de leerlingen spotten er over en schilderden toepasselijke karikaturen op den muur. 
Ik deed daaraan niet mede, omdat mij de zaak te onbeduidend toescheen; maar toch geloofden de docenten, dat ik de aanvoerder was.

Op zekeren dag, toen de leeraar ons met eene biddende en huilerige stem smeekte, toch geene bokken te worden en verdoemd om aan de linkerzijde te zitten, scheen ik eene iet of wat te sterke grimasse getrokken te hebben, zoodat de overige scholieren hardop begonnen te lachen.

De andersizachtmoedige leeraar vloog op mịj toe; ik riep hem toe, dat ik geene straf verdiend had, maar, daar hij bleuf doorganu, nam ik een klein testament op, dat naast mị lag, en wierp hem dat naar het hoofd. Verbaasd bleef hij staan, en ik zeide toen bedanrd: »thans heb ik straf verdiend, laat mij nu maar in de doos stoppen."

$1 \mathrm{k}$ bleef daar een uur in zitten, toen mijn vader kwam en mij, zonder een woord te zeggen, naar huis bracht. Ellke poging tot eene oplossing leed schipbreuk op mijn onbuigzaam karakter el mijn onwankelbaar streven naar onafhankelijkkheid, en ik verklaarde ronduit, dat niets ter wereld mij weder er toe brengen kon, die les opuieuw bij te wonen. Deze zaak baarde opzien, maar zij werd gesmoord en door een' huisvriend wijselijk uit de wereld geholpen. Deze was de beminnenswardige en met echten dichtergeest bezielde Hofpredikant SACHsE*). Hij gaf mij uit eigen beweging

*) Ik denk nog steeds met oprechte hoogaehting aan dezen zeldzaam rechtschapen man. Hoe hij en onze geestverwanten over mij dachten, sprak hij in een gedieht uit, hetwelk hij mij in latere jaren op een groot fecst, dat de Naturforsehende Gesellschaft mij ter eere graf, overhandigde. Ik geef het hier naar den oorspronkelijken druk terng, omdat het het talent van den eerwaardigen man treffend kenșrhetst. Tot beter begrip moet ik ex bijvoegen, dat het handsehrift van mijn slangenwerk toen gereed voor den druk lag; dat ik op het punt stond om mijne bruid Connelis Buddingri', eene geboren Nederlandsche, die een jaar bij mijne ouders vertoefd had, af te halen, en dat de voornaam van mijn' vader "David" was. 
privaatonderricht in den bijbel en het Christendom, en dit onderricht was verstandig. Ik dacht bij mijzelven: „Wacht maar! gij zult pleizier van mij hebben." En inderdaad tooude ik bij het examen de knapste te zijn, zooals het trouwens ook mijne gewoonte was, in elke schoolklasse waartoe ik bevorderd werd, zoo spoedig mogelijk de eerste plaats mach-

\section{DEN SCHEIDENDEN $\triangle M$ M 8 MOVMMBER 1836 VON DER NATURFORSCHANDEN GESELLSCHATT DES OSTERLANDIS ZU ALTENBURG.}

\section{Mru. Es ist so köstlich etc.}

Wohlan! heut gebt der Fröhlichkeit

Die Wissenschaft zur Beute.

Es hat das Forschen scine Zeit

Und ihre Zcit dic Freude.

Benutat die Stunde, dic uus winkt

Und liebe seltne Gäste bringt.

O Priester $D$ u im Isisdienst,

Uns hold in weiter Fcrue,

Der $10 \mathrm{u}$ im Vatcrhaus erschienst,

Gelockt ron 1) e i u e m Stcrne,

Nimm in der alten Freunde Reihu

Heut noch einmal ein Plätzchen ein.

Hier, wo der Knab' in Wald und Flur

Nach Schmetterlingen jagte,

Wo das Geheimniss der Natur

Zuerst dem Jïngling tagle,

Hier grïssen wir den Mann der Kraft Im Lorbeerkranz der Meisterschaft.

Wie strömmt von Seinem Ehrenplatz

Auf uns auch Licht und Lebeu!

Wie viel gab Er aus seinem Schatz!

Wie viel wird Er noch geben,

Briagt uns nicht die Bataverin

Aus Seinem Aug', aus Seinem Sinn.
Denu seht, es steht der Ophiuch

An cincm andern Himmel!

1) Der sich bisher mit Schlangen trug,

Der flieht jetz ibr Gewimnmel, Zur Taube, die sein Hcrz umstrickt, Ist schncll sein Stembild fortgeräckt.

Und mit Ihm flicgt Sie wieder heim, Die kr uns anvertrante, Von deren Lippen Honigseim

Der Charitinnen thaute.

Zieht fröblich hin! Die Hoffuung spricht:

I h r Lieben, I h $\mathrm{r}$ vergesst uns nicht.

Zieht hin und baut ein warmes Nest

$\Delta \mathrm{m}$ feuchten Meercsstrandc.

Der Segen folgt nach Nord und West

E u c h ans dem Osterlande.

Jiasst blüh'u auf Ilollands sicherm 1)amm Der Zweige viel von Da $\nabla$ i $d$ s Stamm!

Jetzt gill's, der Freude Silberblick

Im Glase zu erbaschen.

Wir trinken all' auf E u e r Glück,

Doch nicht aus Leydner Flaschen. Wie fern Ihr zieht, I hr blcibt uns nah; Hoch Hermann und CorneIia! 


\section{(11)}

tig te worden, hoewel ik de verkregene loftuitingeu door allerlei grappige streken eerigszins temperde*).

Tk vermam nu ook, dat dit geval de aandacht ran de regeering op mij getrokken had, wawrom ik mij echter geens-

*) Als men mij onreehtvaardig behandeld had, verzon ik ook wel ernstigere grappen, zooals b. v. de navolgende: Het schoolgebouw stond op eene-binnenplaats. Gelijkvloers was de Career (do doos) en rle rommelkamer, op de eerste verdieping waren kleiuere kamers, en op de bovenstc verdieping onder anderen eene zaal die wel 50 leerlingen bevatten kon. De doeent sloot mij eens, wegens een klein vergrijp, gedurende het middageten in deze zaal op. Ik hesloot hem een lesje voor het vervolg te geven. Aehter de ouderwetsehe kaehel van de zaal stond cen reusachtige inktpot, met inkt gevuld, en daarnaast lag een penseel. Ik makte daar gebruik van om de vier witte muren van de zanl met allerlei karikaturen van den docent en diens vrouw te beschilderen. Na gedanen arbeid, en nadat ik alle inktkokers vuil gemaakt had, decd ik een venster open, klom er uit, sloot het weder, en met de voeten op een klein, nauwelijks een voet breed afdakje rustend, liep ik met de armen balanceerend langs den loodrechten muur verder, totdat ik op eeu laag dak van het naastbijgelegen huis belandde. Van daar liet ik mij niar het naaste venster van do eerste verdieping afglijden, opende dit en klom in de kamer, warna ik het venster wedter sloot en $\mathrm{mij}$ in een boek verdiepte. Ik luisterde. Ilet uur, waarop de custos de deur van de zaal zoude openen, sloeg. De jongens stormden naar binuen, maar in mijne plaats vonden zij, zooals zij zeiden, "eene ledige sehilderijgalerij." Een ontembare sehaterlach weerklonk. De docent werd geroepen, hij liet de zaal ontruimen, en ontsloot de lagere kamers. Hier vond hij mij, net de ellebogen op de tafel en het hoofd tusschen de handen zitten. "Hoe kom je hier?" vroeg hij. "Wat voor een vraag is dit?" antwoordde ik : "U hebt mij immers hier opgesloten" "Ik", zeide hij, "Ik heb je imıners boven in de zaal opgesloten." "Zoo! hoe kom ik dan hier?" De man stond versteend. Zooals altijd, bij buitengewone gevallen, werd mijn vader gehaald. Liegen was mijne gewoonte niet, maar, daeht ik, dleze grap is toch wel een lengen waarl on ik zeide slechts tot mijnn' vader: "Men heeft u rorteld wat er geheurl 1s; oordeel zelf". Hij was overbluft, want van zulk eell waagstuk had niemand zelfs gedroomd. Mijne vriendschap met dezen docent bleef trouwens ongestoord tot zijn' dood roortduren. 
zins bekommerde, omdat ik van deze zaak, die voor mij afgedaan was, voor goed afscheid genomen had.

Ik moest nu aan de Academie komen en kon elk rak kiezen, behalve dat van de natuurwetenschappen; dus een vak naast hetwelk ik müne lievelingswetenschap bestudeeren kon. Maar de Theologie scheen mij te bekrompen toe en zich binnen te enge kringen te bewegen; de Rechten te spitsvondig; bespiegelende Wijsbegeerte te bodemloos; Philologie te schoolmeesterachtig; zuivere Mathesis te nuchter en te droog; Geneeskunde te duister en te tijjdroovend ${ }^{*}$ ). Ik gaf derhalve de voorkeur aan de lucratieve zaak mijns vaders, maar met het geheime voorbehoud en vast besluit, mij bij de eerste ernstige gelegenheid daarvan los te maken.

Mijn vader was des te meer met dit voornemen ingenomen, omdat de door hem bewonderde J. J. Rousseau iets dergelijks aangeprezen had. Iu de zaak getreden, hield ik de boekhouding, droeg zorg voor de correspondentie en streefde er naar, mij in alle richtingen praktisch en technisch te bekwamen, hetgeen mij mijn leven lang uitmuntend te stade is gekomen. Er schoot, behalve de avonden, op zonen feestdagen overvloedig tịjd over om allerlei studies te maken, en de autodidact genoot daarbij het voorrecht, door zijue eigene oogen en niet door die van den leermeester te leeren zien; een ouberekenbaar voorrecht, want slechts op dien weg ontdekt men iets nieuws. Ik maakte daarbị zooveel mogelijk uitstapjes, en zette de reeds in jongere jaren begonnen voetreizen regelmatig voort, terwijl ik daarbij het doen en laten van elken stand gadesloeg, om de totaal-verhouding

*) Een van mijne broeders, Dr. med. Franz SchuEgel, evenals ik een vereerder der Natuurlijke Geschiedenis, nam de proef met het medische vak, maar guf het trots eene vecljarige, gelukkige en rendeerende praktijk, weder op, omdat het hem stuitte als kunstenaar beschouwd te worden. Hij werd toen Directeur van de Diergaarde in Breslau. 
der menschelijke maatschappij behoorlijk te kunnen vatten en waardeeren. Behalve Leipzig, bezocht ik ook dikwijls Dresden. De bergwerken van Freiberg, de rotsen van de omstreken van Altenburg, alsook de naastbij gelegen gebergten, leverden voortdurend rijjken toewas voor mijne verzamelingen. Kortom, ik voelde overal een prikkel om mijne verdere plannen voort te zetteu.

Aan de politick schonk ik alleen dan mijne aandacht, wanneer zij in de geschiedenis ingreep. Il las couranten slechts" onder tafel, waarbij ik trouwens geen tijd voor de zoogenaamde " Leading Articles" had. Voor het jeugdig geslacht waren toen bovendien de tijdsomstandigheden zeer treurig. Na de oorlogen volgden twee jaren van hongersnood. De groote menigte, wars van alle onlusten, had alle belangstelling verloren, scheen alleen te leven om welvaart te verkrijgen, en droeg den muilband, dien men haar aangedaan had, met onverschilligheid. De stormachtige jeugd, door eene edele vlucht bezield, vernietigde haar eigen werk door gebrek aan doorzicht en door overdrijging. Alles nam een' anderen keer, dan bedaarde lieden verwacht hadden. De stadssoldaten, die binnen de poort op banken zaten, en bij de aankomst van een' vreemdeling of een' wagen humne breikous wegwierpen, de slanpmuts voor den steek verwisselden, let oud schietgeweer in den arm namen, en den aangekomene een donderend "halt"! toeriepen, warell wel is waar afgeschaft, en met hen de neuswijjze poortschrijjvers (kommiezen), die den reiziger defiig wachten lieten; de »insolence of office" der politiebeambten was wel wat minder geworden; maar daarentegen werden aan de andere zijde, de teugels strakker aangetrokken en daarduor menigeen van zijn vaderland afkeerig. Ools mij was het reeds lang te nauw geworden, en ik werd er ten laatste uitgedreven, toen mijn vader zich eens onvoorzichtiger wijze ontvallen liet, dat ik toch zonder hem niet kon bestaan. "Dat zal ik U toonen!" was mijn antwoord. Ik verliet dadelijk de kamer, palste mijne spulletjes bijeen en begaf mij, zonder afscheid van hem 
te nemen, op reis, behalve eenig gercer geld, in het bezit van eene beurs, goed gespekt met ringetjesdukaten en andere oude munten, die mijue moeder en grootmoeder, in een geheim laadje van de secretaire, op zijde gelegd en mij heimelijk toegestoken hadden. Ik vcrliet, nog geen achttien jaar oud, met een zwaar hart mijne vele beschermers en vrienden, maar zonder rouw mịjne vaderstad, die mij, hoevvel eene residentie, nuchter, luisbakken en kleinsteedsch toescheen, en nam niets mede dan de Saksische eerlijkheid, gemoedelijkheid en beleefdheid, laatstgenoemde echter slechts in beperkten vorm. Ik bcgon mịne voetreis over Chemnitz en Freiberg naar Dresden, en kreeg in laatstgenoemde stad huisvesting bij een' vriend.

In die stad bleef ik een paar jaren, en vond ik dikwerf gelegenheid, de omstreken in wijden kring te onderzoeken. Maar Dresden kon mij op den duur niet boeien. Ik had door buitengewone zuinigheid, door allerlei werk en het geven van lessen, eene kleine som bijeengespaard, en besloot daarom met Paschen 1824 eene grootere voetreis te ondernemen, cn die tot Weeuen uittestrekken, want daarheen werd ik gelokt door den naam van het K. K. NaturalienKabinet als eene model-inrichting en de beste technische school.

Nadat ik mij onderweg 14 dagen in Praag opgehouden, en er met het volksleven kcnnis gemaakt had, wandelde ik naar de keizerstad. BREH had mij recommandatie-brieven voor die stad medegegeven, o. a. ook aan Jos. NATTEnEn, die mij welwillend ontring en mij weldra tot eene jacht op Ilc Donaueilanden uitnoodigde. Gedurende het gemoedelijke rustunrtje, bood liij mij̄ een klein baantje aan het Museum aan. Ik nam dit olvoorwaardelijk aan, want ik beschouwde het als den stijgbeugel, van waar ik op mijn geliefkoosd terrein hoopte te komen. Ik had thans eene groote inrichting tot mijne beschikking, mijne ambtsbezigheden lieten mij tijd voor andere studiën, en ik was bovendien van een toereikend inkomen verzekerd. Door Heckel, dien ik bij 
zijne bezigheden ter zijde stond, werd ik tot een nauwkeurig onderzoek der visschen geleid. Fitzinaer wijdde mij in de vakken der reptiliën en amphibieën in; bij den zonderling Breuser leerde ik velerlei, zelfs des avouds in den kelder van Esterhazr, waar hij altijd alleen zat, niet wilde toegesproken zijn, maar zich dikwijls aan onze vroolijke tafel plaatste en fijne wijnen liet schenken. Tot DrEIER, een ervaren anatoom, gevoelde $\mathrm{ik}$ mij bijzonder aangetrokken, en hij werd mij een beminde vriend en leermeester; maar bovenal "was het de hongaarsche graaf PETHíry, die mïj met liefde opnam, innige vriendschap met mij aanknoopte, en mij, onder bedreiging van het verlies onzer broederschap, dwong, huisvesting, kost en alles wat ik wenschte met hem te deelen *), toen hij er achter gelzomen was, dat ik, on geld voor boeken te sparen, mijn middagmaal tot een in de eenzaamheid genoten stuk brood en dronk water,had beperkt. Hij was een man van grondige kennis, vooral in de dierkunde, en een van die edele en reine karakters, die met den eens beproefden vriend de laatste bete en het laatste geldstuk zou gedeeld hebben. Mannen, zooals ik dikwerf onder zijne landslieden aangetroffen heb, en die niet door den invloed der naweeën van het Weener Congres ziekelijk of vergiftigd waren geworden.

Ik leefde van nu af onder zijne vrienden, in welker kring het gesprek toen meer in het latijn $\dagger$ ) dan in het hongaarsch

*) Terwijl Schtegen van huis was, liet graaf PethéNy diens gebeele meubilair, uit hot kamertje waar hij woonde, naar zijn eigen huis transporteeren, zoodat ScHuEgEL, toen hij thuis kwam, geen bed meer vond om in te slapen, en zijue hospita hem beduidde, dat bij nolens volens lij graaf Pвтни́NY moest ganan overnaeliten.

G. S.

$\dagger$ ) Toen ter tijd spraken alle besehaafde Hongaren latijn en wel met eene buitengewone gemakkelijkheid. Hoewel alle grammatieale en syntactisehe regels daarbij in het oog gehouden werden, was bet nu juist niet klassiek te noemen, manar het was doeltreffend en paste voor de tijdsomstandigheden, zoodat men gaarne verontsehuldigde, dat zij ieder- 
of duitsch gevoerd werd. Ja, ik werd zelfs in hunne dwepende vaderlandsliefde, met eene soort van feestelijke schildverheffing, tot broeder gekozen, toen zij vernamen, dat mijn overgrootvader, in den Oostenrijkschen successieoorlog door vorst BATHYANI gevangen genomen zijnde, in diens dienst getreden was, en op zijne goederen, waar ook mïn grootvader geboren werd, overleden was. De dagelijksche omgang met lieden uit elken stand van dit merkwaardig volk, alsook het bonte tafereel, dat Weenen door de samenstrooming van zooveel andere rolksstammen nit Oost-Europa en West-Azië bood, leverden overvloedige stof voor ethnographische indrukken.

In het huis van den toenmaligen Directeur van het Museum, Freiherr Von Scmmerber, vond ik eene zeer vriendelijke ontvangst. De kring zijner familie opende voor mij een gedeelte van het hofleven, voldoende om het te doorzien en mij met het wezen en de gebruiken er van vertrouwd te maken *).

Mevrouw Von Schreiber, eene voortreffelijke en zeer beminnelijke dame, was de dochter van den botanicus JACQuin, die ons, hoewel reeds hoogbejaard, des zomers reeds vroeg te 5 uren bij zijnc voorlezingen in den hortus botanicus der Universiteit bijeenriep, en van wiens nagelaten werken zij de uitgaaf bewerkstelligde $\dagger$ ).

een mot Domine in plaats van met Vir aanspraken. Woorden uit die taal verdwaalden soms onder anderc standen, on werden dan op eene hoogst potsierlijke wijze gobruikt, zooals bij voorbeeld een zeker grenswachter deed, die de gewone vraag: "Waar komt gij van daan?” met "unde sunt" verwisselde.

*) Dikwerf werd hij genoodigd om bij de hofdames, die des avonds op het terras van het slot een luchtje schcpten, verhalen te doen over zijne waarnemingen der natuur; eerst toen hij bemcrkte, dat zij meer belust waren op de vergissingen in het spreken, dic hij als Noordduitscher onwillekeurig makte, en warin let onderscheid tusschen het Noordduitsche "Schwanz" en het Zuidduitsche "Schweif" eene grootc rol speclde, dan op de kennis der natuur zelve, onttrok hij zich aan deze "Conversaziones".

G. $S$.

†) Ieder botanist kent de geschiedenis van de $J_{\text {ACQUINS, maar de }}$ 
Behalve kleine en groote uitstapjes, tot zelfs naar Hongarije, was de muziek eene mijner meest geliefkoosde uitspanningen. De voortreffelijke strijkquartetten van reizende artisten uit Praag hadden reeds vroeg in mijne vaderstad den lust voor dezen tak der kunst opgewekt. Ik lron toen nog de laatste klanken van het onder BEErHoven tot volkomenheid gebrachte quartet hooren. BeEthoven, hoewel een rolksman, was door het naar het nieuwe en den glans hakende publiek, dat toen geheel door Rubini, Tamburini en Sonntag in beslag genomen

Tevergeefs had men het groote BEETHoven-concert, waarvan Schindere ons het reusachtig programma bewaard heeft, gearrangeerd. Eerst lang na zijn' dood, steeg de geest van dien onsterfelijken man weder in de algemeene waardeering. Wij achtten ons reeds gelukkig, wanneer wij naar den on-

ware reden van hunne verhuizing naar Weenen wordt gewoonlijk over het hoofd gezien. Zij gesehiedde op aandrang van VAN SwIETEN, Dcze man, gesproten uit eene onde familic, welker zetel in den omtrck vau Leiden stond, was, zooals bekend is, een leerling van BoenHAAVE. Als zoodanig wist hij zich, meer door zijne hooge geboorte, door zich als cen man van de woreld voor te doen, door zijne veelzijdige kennis, ondervinding, bedanrdheid on harmonische vorming, dan door seheppende kracht gesteund, een' grooten naam te verwerven, cn werd dientengevolge door Maria Tueresia naar Weencn beroepen. Het besluit, het land zijner vaderen te verlaten, schijnt hem zwaar to zijn gevallen; en hij lict zieh cerst na eene herhaalde uitnoodiging, en door de omstandighleid dat zijne positie in Leiden, als strenggeloovig katholitk, zooals zijne voorvaderen altijd geweest waren, bij de toen in Nederlund heersehende onverdraagzammheid, schandelijk onaangenaam gemaakt werd, bervogen, er toe overhalen, dit beroep an te nemen. In Weenen angekomen, liet liij om dezclfde reden de heile $J_{\text {ACQUIN⿴囗十 }}$ uit Leiden overkomen, en bovendien kwamen ook een zeker getal in de Boerhanfsehe sehool gevormde vrocdvrouwen mede, welker nakomelingen in mijn' tijl in Weenen nog een' grooten roep genoten. V V SWIETEN kwam, zooals hekend is, in Wcenen tot grootc waardigheden, en zijn eenige zoon, de nitstekende muziekkenner, de vriend van Mozart, BEETHOvEN en HAYD'N, voor wiens "Sehöpfung" hij het gedieht maakte, sticrf kinderloos in Weenen. 
bereikbaren meester in stilte, op zijne wandelingen, hetzij in Weenen of in Baden, luisteren konden.

Ilk had ongeveer een jaar in Weenen doorgebraeht, toen er een brief van Temminck, toen Direeteur van het Nederl. Rijks Museum, aan zijn' eollega in Weenen aankwam, Hij deelde hem mede, hoe hij in het jaar 1820 deze instelling had gestieht; dat de beide geleerden Dr. H. Boré en Dr. H. M $\triangle$ CKLoT, die hem tot nu toe als eonservatoren ter zijde gestaan hadden, als natuurkundige reizigers zeer spoedig naar Indië zouden rertrekken; dat hịj ze niet wist te vervangen, en besloot met de vraag of er missehien in Weenen een jong, wetensehappelijk gevormd menseh te vinden zou zijn, die niet alleen in de dierkunde t'huis was, maar ook praktisehe vorming bezat, onversehillig of hij zijne aeademisehe loopbaan al dan niet voleindigd had. Ik nam dit roorstel aan *), maar onder voorwaarde, dat ik de eolleges voor onderseheiden vakken in Leiden zoude mogen volgen, en mij voor reizen in vreemde landen moeht voorbereiden.

TEMmixck's antwoord behelsde den wenseh eener zoo spoedig moggelijke afreis. Weinig dagen daarna $t$ ) verliet ik Weenen en begaf mij over Praag naar Altenburg.

Het bezoek aan mijne vaderstad was met bijzondere zwarigheden verbonden. $1 \mathrm{k}$ was door miju plotseling vertrek met miju' vader in onmin geraakt, had in mijne driejarige afwezigheid niet de minste ondersteuning van hem gevraagd, en wij hadden sleehts door derden van elkander gehoord. De eenige brief, dien ik ontring, behelsde de mededeeling, dat ik, dienstpliehtig geworden zijnde, t'huis komen en onder

*) Eehter niet zoo dadelijk, want de positie in Weenen beviel toen mijn' vader zeer goed. Eerst toen Von Schreiber hem er op opmerkzaam maakte, dat hij èn als Noordduitseher èn als Protestant in het Zuidduitsche, Katholieke Oostenrijk weinig of geen kans van promotie had, liet hij zich overhalen dien nieuwen werkkring te aanvaarden.

G. S.

†) Zijn reispas is afgeteekend op 20 April 1825.

G. S, 
dienst moest gaan, daar ik anders mijn erfdeel zou verbeuren en als deserteur zou beschouwd worden. Ik liad daarop geantwoord, dat ik den Staat mijn luttel erfdeel cadeau deed, en dat ik, hoewel verbanuen, toch wel mijn' weg door de wereld zoude vinden.

Thans echter ontbraken mij de middelen om verder te reizen en om in Leiden te kunnen optreden, en bovendien had mijn hart mijj reeds lang gezegd, dat het tijd werd te huis vrede te sluiten. Ik begaf mij dan ook leechtstreeks naar de vaderlijke woning, edoch uit voorziehtigheid eerst des middernachts, uit de naastgelegen stad in een huurrịjtuig er heenrijdende. Ten einde mij niet te verraden, en denkende aan de voorliefde van mijn' vader voor de fransehe taal, riep ik hem, toen hịj op mijn herhaald kloppen het bovenslaapkamervenster opende, toe, dat ik een oude kennis uit de oorlogstijden was, die zich, teu einde hem te verrassen, niet noemen wilde. Hij draalde nog eu riep nij toe: "mais, Monsieur, à minuit, ou ne reçoit pas tout le monde." Ilk schreeuwde echter met fransch ongeduld eu beslistheid terug: »mais moi, je ne suis pas tout le monde, ourrez seulement, et vous verrez." Dit hielp, de voordeur werd opengedaan, maar mijn vader herkende mij eerst, toen ik mij genoemd had en hem in het Duitsch aansprak. Wij waren beiden tot schreiels toe bewogeu. Moeder, zusters en broeders werden bijeengeroepen, ik deelde hun het bericht van nịjn beroep naar Leiden mede. Vreugdevolle verrassing en verwondering straalden uit aller gelaat, en mijn vader sloot de scène met de woorden: »als twee onbuigzame naturen op elkander stooten, verwijderen zij zich dikwerf in tegenovergestelde richting; ik heb het altijd goed met je voor gehad, en gij, hiervan overtuigd, hebt eigenlijk slechts comedie gespeeld, maar je hebt ze goed gespeeld. Je hebt je eigen weg gevonden, ik zal mij vau nu af aan daarbij bepalen, met deelneming toe te zien hoe gij het maken zult." Ik wilde, om geen aeliterdoeht te wekken, dienzelfden nacht $\Perp$ og wegreizen, maar mijn vader hield mij daarvan 
terug. Hij begaf zich, in het bcwustzijn van zijn zelfvertrouwen en zedelijken moed, den anderen morgen naar de invloedrijkste mannen der regeering, en deelde hun het gebeurde openhartig mede. Deze, vooral de overste Von Stabacir en de heeren Stuttarhaim en Von der Gabetintz, de vader van den beroemden taalgeleerde CoNox rox Der Gabelindz, provoceerden terstond een Hertogelijk besluit*), waarbij mij, in overweging genomen de zeer bijzondere omstandigheden, voor altijd vrïdom van militairen dienst werd verleend. Ook die mannen hebben mij tot hun' dood toe hunne deelneming betoond. Wat mij echter het meest genoegen deed, was, dat zich in de geheele stad geene enkele stem tegen dezen buitengewonen matrcrgel verhief $\dagger$ ).

Ik reisde nu over Jena, Weimar, Cassel on Keulen naar Leiden, waar ik den $25^{\text {en }}$ Mei 1825 aankwam. Onderweg bracht ik Brenm een bezoek, alsook OKEN, met wien ik sinds briefwisseling bleef houden, niet over natuurphilosophie, maar over de wezenlijke wetenschap en over de Nat. Gesch. van Puinius, die hij van plan was uit te geven.

Een' recommandatiebrief aan GöTHE gaf ik niet af, daar il begrcep, dat ik voor zulk een' man toch niets zijn kon

In Leiden werd ik met dc grootste voorkomendheid in den kring van eene reeks van merkwaardige mannen opgenomen, en in den draaikolk van een levendig, wetenschappclijk leven medegesleurd. In de gastrijje woning van TwMMINCK voelde ik mij weldra t'huis; eveuzoo in die van REIN-

*) Het besluit is gedagteekend 4, Mei 1825 .

G. S.

†) Gedurende die voorvallen sloeg men mij voor mij tot vrijmetselaar te !aten inwijden. Als een vijand van al wat geheimzinnig en verouderd was, als ook van uiterlijken sehijn, en omdat ik bij mijn' vader, die een' hoogen rang in het genootsehap bekleedde, genoegzaam van haar waren, hoewel geheet onsehuldigen, aard overtuigd had, beschouwdo ik de zaak als nutteloos en bleef voor deze voorstellen doof. 
WARDT, die eenige jaren vroeger van zijne wetenschappelijke reizen uit Indië was teruggekeerd: iemand, die eene verwonderlijke en omvattende kcnnis in zich vereenigde, en, wat meer zeggen wil, een der voortreffelijkste menschen was. H. BoIÉ, als mensch niet minder uitmuntend, legde toen de laatste hand aan zijne Erpétologie de Java. De beroemde botanicus BLUME liet mij, hoewel iets latcr, menigen blik in de schatten der Javaansche flora werpen, en het strckte mij tot een genoegen, hem door het vervaardigen der platen voor de Anatomie der Brugmansia, aan welke zijn teekenaar vergeefsche pogingen had besteed, van nut te zijn. MACKLoT, de osteoloog, mineraloog en physicus, wekte belangstelling door zijn' haast dolzinnigen reuzengeest en zijne herculische kracht. De latere hoogleeraar KAup, die mij in zekeren zin zijne plaats hier afstond, boeide mij door zijn' eigenaardigen geest en zijn' buitengewouen aanleg voor het teekenen en de praktische werkzaamheden. Met Fisciıe, den schrijyer der » Synopsis Mammalium," begon ik langzamerhand samenwerking voor te bereiden. In SALOMoN MüLLER leerde ik een' even zoo uitnemendelı als waarheidslievenden waarnemer' kennen.

Cantraine, later hoogleeraar aan de hoogeschool te Gent, betooverde mij door zijn' echt franschen geest; en de beminnenswaardige VAN OORT, een allercharmantst en welopgevocd jong mensch, teekenaar bij het Museum, zorgde voor aallgename conversatic gedurende onzen vrijen tijd.

Temminck, een ervaren man der wereld en hoveling, wist zijn personeel met handigheid, een' scherpen blik, en zonder dralen te kiezen. Hoewel het fransche element bij hem overheerschend was, en hij de Franschen zijne meesters placht te noemen, was hij toch op duitsche lcest geschoeid; hij had lang bij Meyer en OfFenbach vertoefd om de duitsche vogels te bestudeeren, en hij gaf de voorkeur aan het karakter der duitschers en der duitsche vrouwen boven dat der Franschen, en zag zich let liefst door Duitschers omgeven. Hij had, bij de stichting ran het Museum, H. Kvnu tot zich geroepen 
en hem aan het hoofd eener onderzoekingsreis geplaatst, aan welke de jonge Nederlandsche geleerden $\mathrm{V}_{\text {AN }} \mathrm{H}_{\text {ASSELT }}$ en $\mathrm{V}_{\text {AN }}$ RAALTL, als ook de teekenaars KuILtJes en MAUrevert, toegevoegd werden.

De wijze hoe hij Borḱ machtig werd, was zeer eigenaardig. Deze had, als student in Heidelberg, eene kritiek van 'Tемminck's Manuel d'ornithologie gepubliceerd. Tемminck, in plaats van zich over het gispen van verscheiden fouten tegen de wetenschap geraakt te gevoelen, schreef integendeel aan Boxí om hem eene pluats aan het Leidsch Museum aan te bieden. Boxé nam het voorstel aan, maar beval tevens Macklot en S. Mülder aan, welke Temminck ook zonder complimenten dadelijk liet nakomen *).

Nadat BoIÉ, MackLoT en MüLLer den 21 en December 1825 met de brik Dijkzigt uit Hellevoet naar Indië vertrokken waren, manı ik voorloopig aan het Museunı hunne werkzaamheden betrekkelijk de gewervelde dieren en de zoötomie waar. Nog werd ik in het jaar 1827 bij de Regeering als reizend naturalist aanbevolen, maar toen het bericht van Boxé's dood, dien Temminck als zijn' opvolger had uitverkoren, kwam, smeekte hij mij het Museum niet te verlaten. Ik gaf toen eindelijk mïne reisplannen op, omdat ik begreep, dat ik, in het middenpunt der wetenschappen, algemeene diensten bewijzen kon.

Aanmoediging voor mijn beoogd levensdoel heeft mij nooit ontbroken. Reeds in mijne prille jeugd had mij eene passage in het toenmaals, zoo geachte werk van KNrGge, »dat de mensch alles bereiken kan wat hij wil, als hij het slechts goed begint" getroffen. Maar ik dacht daarbij: »als de fortuin hem gunstig is". Ввенм zeide mij bij het eerste afscheid: „blijf der wetenschap getrouw, zij zal U eer aanbrengen". VoN SchreIBER ontsloeg mij met de woorden:

*) Wij stippen hierbij aan, dat T'emminck, om SchlEget voorloopig bij het Museum te houden, hem den lsten Juni 1825 als praeparator ad interim bij die instelling liet benoemen.

G. S. 
- Vertrek gerust! gij zult niet op eene der lagere treden van het ambtelijk leven blijven staan." Boré schreef uit Indië over mij aan TEmminck: »Conservez ce jeune homme, il ira loin". Eigen overschatting was en is nog steeds mijne grootste vrees. Ik had immers ook geen ander doel voor oogen, dan eene der wetenschap waardige instelling te scheppen, en dat dit eerst zeer laat naar mijn' zin verwezenlijkt werd, is aall het noodlot te wijten. Bij besluit van den 29en November 1828 werd ik eindelijk officieel tot conservator der bedoelde vakken benoemd*).

De last om de reeds toen aanzienlijke zoölogische en osteologische verzamelingen verder te determineercn en te rangschikken, eene zoötomische verzameling der zachte deelen aan te leggen en bovendien alle technische werkzaamheden te leiden en te bewaken, viel mịj, bij mijne langdurige oefening in die vakken, niet moeilijk; de moeilijkheid alleen was tijd te winnen voor zolfstandigen arbeid en eigen studie. Ik deed al het mogelijke om mijne nog ontbrekende kennis aan te vullen.

Ten gevolge van eene ingeschapen piëteit voor degelijke en oudere lieden, had ik mij, dwepender wijze, de beroemde Leidsche Hoogeschool als het model voor alle dergelijke instellingen voorgesteld. Hoewel nu de groote geleerdheid van enkelen niet te miskennen viel, zoo vond ik toch veel wat verouderd was. Theologie en Philologie, de steeds in Nederland het meest bevoorrechte vakken, bloeiden het beste. De eerste kon zich echter niet ontwikkelen in eene maatschappij, die elk vrij onderzoek met ketterij en ongeloof gelijk stelde; terwijl de andere zich hoofdzakelijk bepaalde bij de, wel is waar gewichtige en toen in Duitschland dikwijls verwaarloosde grammaticaal-kritische richting; maar zij bleef meestal

*) In werkelijkheid had hij ze reeds sinds 1825 bekleed. Men zie zijne verhandeling over eenen in het jaar 1826 aan de Noord-Holl. kust gestranden Vin-Visch (1e kl. N. Verh. Kon. Ned. Inst. III, 1826, met 2 pl.)

G. S. 
slechts het middel, en niet het doel, om den geest en den smaak te vormen en een juist inzicht te verkrijgen in de kunstgeschiedenis der oude Grieken en in het leven en streven der onden in het algemeen. Evenmin kon de daarnaast bloeiende gevoelskritiek van een' Peerlikamp behagen, omdat zij in hare afgesloten subjectiviteit zooveel schoons uit HoRatius en Virgilitus verworpen had, en alleen voor den schrijver en eenige hem nabootsende leerlingen paste.

De Physica werd op eene wijze behandeld, die op zijn hoogst voor een gymnasium paste. De stndie der Nederlandsche taal stond op een zeer laag peil. Het doordringen in den geest der duitsche, engelsche en italiaansche poëzie ontbrak in zoo groote mate, dat ShaKesPeare volgens de uit het fransch vertaalde alexandrïnen van Ducis gespeeld werd, en dat mij eens de toen het meest gevierde onder de Nederlandsche taalkundigen zeide, dat hij in zijne vertaling van den Orlando furioso, in plaats van de ottave rime, alexandrijnen gekozen had, om meer speelruinte voor de keuze van uitdrukking te verkrijgen. Desniettegenstaande werd die verknoeide vertaling zoo gunstig opgenomen, dat de beroemde hoogleeraar den eersten zang van het gedicht in achttien verschillende steden van het rijk moest voorlezen.

En dit gebeurde terwijl de geestige en emphatische dichter BiLDerdiJK nog leefde, maar wegens zijgn' bịtenden, satirieken geest naar den achtergrond verdrongen was.

$\mathrm{Na}$ den dood van den veelomvattenden en scherpzinnigen Brugmans, die, terloops gezegd, het talent van LichienSTEIN erkend en hem naar de Kaap de Goede Hoop aanbevolen had, belastte men een' theoloog met de colleges over zoölogie: een zeer geleerde, maar in dat vak geheel onbedreven man. Hij was de leermeester van J en laatstgenoemde vertelde mij o. a. dat hij steeds den kalkoen (Meleagris gallopavo) met het parelhoen (Numida meleagris) verwisselde, omdat op de etiquette van het hart van laatstgenoemden vogel »Cor meleagridis" stond.

De colleges van SANDIFonT over menschelijke anatomie 
en zijne snijkundige oefeningen waren zeer leerrijk; maar ten opzichte der weefselleer en physiologie was men niet verder dan Bichat en Richerand gekomen. Rudolphi's handboek bracht ons eenige schreden verder; en VAN DEEN liet mïj aan zijne physiologische onderzoelzingen deelnemen, en verschafte mï daarbij eene nadere kennismaking met de deensche taal.

Later gaf ons de wetenschappelïk gevormde geneesheer GoвÉE een privaatcollege over histologie en physiologie, en eindelijk haalden wij jaren later bij HALBERTsMa zeer veel in. Maar hoevele, altijd vernieuwde, studiën zijn niet noodig om slechts eenigszins de phases te volgen welke deze duistere wetenschap doorloopt.

Reinwardt las op zeer zorgvuldige wịze, behalve zijne hoofdvakken, chemie en botanie, in den aanvang ook mineralogie en geologie, en werd mijn meest beminde leermeester *).

*) Schleger had zich den $16 e n$ October 1830 als student laten insehrijven, en hield trouw college, zooals uit de door mij gevonden certificaten van Penrukamp, Sandifort, Jacob de Gelder, ReinWARDT enz. blijkt. Hij zelf teekent hieromtrent aan:

"Bij het doorsmuffelen van oude, half of geheel vergeten sehrifturen, vond ik een testimonium, dat REINWARDT mij gaf om daarvan bij eene eventueele keuze van een' Directeur des Museums gebruik te maken. Toen dit oogenblik, velc jaren later, aanbrak, hield ik het voor overbodig mij daarop te beroepen, maar laat het thans hier volgen, omdat het mij niet onverschillig is, dat men wete hoe deze gevierde man over mij daeht.

Sex fere anni sunt cum viri doctissimi et in Naturae rerum scientia versatissimi Hæan. BoIé et H. C. MАCKLot Historiae naturalis augendae et regii rerum naturalium Musei quo Leida superbit loeupletandi gratia iter in Indiam orientalem parabant. Venit circa idem tempus in hanc urbem Hermannos SchuEger, vir honestissimus, Vindobona evocatus, et illorum suecessor, Musei praefecto adjunctus, ut omnium rerum naturalium quae ad vertebratorum animalium historiam pertinent, in codem Museo custodiam et euram gereret, ad hoc munus obeundum praeparatus, cum diligenti studio Historiae naturalis, tum 
Later hoorde ik nog eens geologie en palaeontologie bij VAN BREDA. Ten einde ook de aronduren te besteden, nam

multis in caesareo Museo Vindobonensi exercitationibus expertissimorum denique huic Museo praepositorum excmplis.

Quo quidem illo in munere quomodo se gesserit Schlegelius, et locupletissima quae in Leydensi Museo exstat, supcllex Zoologica demonstrat, ipsius cura artificiose et nitide composita, ad viventiun animalium formas expressa artisque ex legibus ordine digesta et Praefecti viri illustrissimi approbatio docet; omnium denique qui illa visendi gratia Muserım frequentant, communis admiratio confirmat. Tot labores, ut praestavit Schlegelius, quantum opus fuerit arte, studio. vigiliis, totiusque historiae naturalis scientia, non est quod rerum periti moneantur.

Neque profecto quicquam neglexit quod aut ad muneris officium rite exsequendum conferre, aut quo ipse suam augere scientiam posset. Deliveandi autem cum Naturae studio conjunxit eo felici successu, ut viventium animalium tamquam ipsas vivas imagines operariis ad imitandum ante oculos ponat, observationes vero suas omnes, in quibus elaborantis versatur fidis et nitidissimis illustret iconibus.

Dein Professorum in Leydensi Academia Scholas mathematicas, physicus, chemicas, anatomico-physiologicas, illas denique quibus Historiae naturalis diversae partes tractantur, assidue frequentavit.

Linguas plurium Europae gentium eo usque sibi familiaris reddidit, ut iis non secus ac patrio et vernaculo sermone uti consueverit. Neque inter haec omnia humaniorum omisit studia litterarum, tum veterum tum rcceutiorum, quibus ingenium expoliret et elegantioris sermonis benc scribendi usum sibi compararet. Quibus omnibus cum multiplicis scientiae copiam sibi paraverit ipse, non minus effectum est, ut arti prodesset, et in Historiae naturalis emolumentum suos transferret labores. Argumento sunt plura jam cjus in lucem edita scripta quorum duo, illustrissimae socictati Scientiarum Harlemensi, ut propositis ab hac questionibus respondcret, oblata, digna judicata sunt, quac summo praemio, optimis responsis constituto, aureo nummo ornarentur.

Alia ejus scripta cxtant in novissimis voluminibus quae et Academiae Caesareo-Leopoldina Naturae curiosorum et Instituti regii prima classis ediderunt.

Ad tantam, quae in Schlegelio est, doctrinae copiam, accedunt morum ornamenta castissimorum et suavissimorum, tum quaeque humanitatis officia, quibus omnibus facile sibi amicos paravit, omnesque devinxit qui in ejus consuetudinem venerunt et familiaritatem. 
ik privaatles in de nederlandsche taal en hoogere mathesis. In het laatste vak werd ik nooit t'huis, wel is waar, zooals nog onlangs mijn leermeester tot 1 nij zeide: "omdat ik niet wilde", maar ik betwijfel dit oordeel. Ik gaf dit vak dan ook, na verscheidene jaren er in gewerkt te hebben, op, tevreden een begrip daarvan gekregen en eene strenge methode daardoor verworven te hebben. Ik beoefende des te vlijtiger philologie met een mijner geleerde vrienden, Dr. VermeER, die later naar Amerika verhuisde, waar hij nog leeft. Hij wijdde "mij voornamelijk in Crcero en Lrvrus in, die ik voor" Caesar en Horatius eenigszins verwaarloosd had. Daarom legde hij mij voor de ardigheid elken avond de trouwens aangename straf op, een latijnsch briefje in den stijl van Crcero te schrijven *).

Gedurende het college over chemie was mịjn oog gevallen op een' jongen, aandachtigen toehoorder, wiens gelaat evenzeer den denker als den goedmoedige verried. Hij scheen geene kenuissen te hebben en bleef ten gevolge zijner bescheidenheid geheel onopgemerkt, ja werd zelfs min of meer op den achtergrond geschoven. Ik maakte kennis met hem, vernam dat

Scripsi haec, ut qualis sit, quem inde a multis annis amicum colo et diligo, Schlegelius, plures intelligant, tum ut eum sibi commendiltum habeant, qui auctoritate, consilio, gratio, auxilio prodesse Schlcgelio possint; omues denique, quibus physicarum, artium ct litterarum studia curae cordique sint.

d. Lugd. Bat. m. Januar. MDCCCXXXII.

*) De naturalist is er trouwens met dc oude talen slecht ann toe, want slechts zelden komt hem in zijn rak, behalve bij geschiedkundigc nasporingen, een latijnsch of grieksch boek in handen, en als dit gebeurt, merkt hij spoedig dat veol, vooral in het Grieksch, hem vreemd geworden is Cndertusschen geven de Ouden altijd troost wanneer men, misnoedig over zoortle moderne onverteerbare produkten, ze ter hand neemt. Ik denk claarbij stceds, hoewel in anderc toepassing, aan den schilder David, die op NAPOLEON's viaag waarom hij de schilderijtentoonstelling verliet, antwoorddc: "Je vais me débarbouiller des modernes chez les anciens". 


\section{(31)}

hij KaTSER heette en aan astronomie deed. Uit onde voorliefde voor deze wetenschap, sloot ik mij bij hem aan, waaruit weldra eene hartelijke vriendschap ontstond. Ik volgde al zijne werkzaamheden, en stond verstomd over zijne grondige kennis, zijne zich bewuste kracht, zijn' praktischen geest, en de eenvoudige, natuurlijke helderheid zijner mededeelingen. Ik roorspelde toen zijne latere grootheid, maar hij wees die roorspelling weemoedig lachend af met de woorden : » men zal mij hier nooit vooruit laten komen". Ik had daarover wel willen weenen, maar ik sprak hem moed toe, er op wijzende, dat men niemand tegenover hem stellen kon. En inderdaad, jaren lang wachten, moeielijke worstelingen, en een stoot van buiten was noodig, om zulk een' man een' zelfstandigen werkkring te verschaffen. Er leefden hier toen uitnemende mathematici, maar te vergeefs zag men nar een' astronoom rond. De regeering had voor zwaar geld een grooten teleskoop roor de Leidsche sterrewacht gekocht, maar hij was zoo geheel onbruikbaar, dat bij later voor oud koper, ijzer en houtwaarde verkocht werd. In het land, dat een Constantyn Huygens had voortgebracht, was inderdaad de hoogste van alle wetenschappen reeds voorlang zoo laag gezonken, dat men, zooals LALANDE het in zijn reisbericht over den toestand der astronomie in Europa deed, de $\mathrm{Ne}$ derlanden nog altijd met de woorden:

\section{Hollande.}

\e n'ai trouvé en Hollande, ni astronomes, ni astronomie" afschepen kon.

Eerst toen KaIsEk, niet van hier, maar van zijne Amsterdamsche beschelwers Huydecooper en SilLEm, instrumenten en een' kijker gekregen had, waarmede hij op den zolder zij̄ner woning, door eene in het dak aangebrachte opening, zijne waarneningen doen moest, eerst toen hij den terugkeer van de HALLEY'sche komeet nauwkeurig berekend had, kwam hij iet of wat tot aanzien. Maar toch was nog de invloed Van den toenmaligen deenschen gezant, Baron VoN SELBr, noodig, om hem eene eenigszins zelfstandige positie to ver- 
schaffen. Toen if Enke en Argetander bezocht, waren zij vol van zijn' lof, en had ik dus autoriteiten van den eersten rang om dit hier te verkondigen. Het spreekt van zelf, dat ik een ijverig toehoorder bij zijne voorlezingen, over datwat men populaire astronomie noemt, was; en nadat hij tot hoogleeraar benoemd was, stelde hij het als eene voorwaarde, dat ik hem bij het openen zijncr colleges zonde binnenleiden. Voor mij was het eene groote voldoening, dat ik zulk een' man het eerst, en wel zoo lang alleen, erkend had, en hij zelf placht dit bij elke voorkomende gelegenheid te zeggen.

Ik moet hier nog melding maken van een' jongen Engelschman, St. Clarr Massiah, die in bijzondere mate mijne aandacht trok. Hij had zijne jeugd in de West-Indiën doorgebracht, zijne verdere opleiding in Schotland genoten, en stndeerde nu in Leiden. Hij was ruimschoots met lichamelijke en geestelijke eigenschappen bedeeld, zooals weinigen. $\mathbf{H}_{i j}$ schreef de fraaiste hand, die ik ooit gezien heb, teekende en schilderde meesterlijk in olieverf, sprak en schreef Fransch met eene zeldzame kennis, maakte uitstekende gedichten, was in alle diepten der Engelsche taal en letterkunde doorgedrongen, droeg hare dichters, vooral Shakespeare, met wonderbaarlijke juistheid en onnavolgbare bekoorlijkheid voor, was in zijne leefwijze buitengewoon matig, een volkomen jager, moedig ruiter. Kortom, hij had voor alles het meest merkwaardig talent, maar versmaadde het daarvan een nuttig gebruik te maken. Onder zijne leiding, vereenzelvigde ik mï zoodanig met de Engelsche letterkuude, en vooral met Shakespenre, dat die taal mij toen bijkans tot eene tweede moedertaal werd; en wịi, toen de engelsche tooneeltroep vertrokken was, openbare voorstellingen van enkele tafereelen of van geheele bedrijven uit Sinakespeare of andere engelsche dichters gaven, wat mij later, tijclens mịn langdurig verblijf in Dresden, in den kring van Tieck, Carus, Rietscilet e. a.m. zeer te stade kwam.

De uitgaaf van kleinere verhandeliugen, zooals b. v. die over den gestranden vinvisch en over de speekselklieren der 
slangen had in de eerste jaren van mijn verblijf alhier plaats.

Jeugdige overmoed verleidde mij bovendien tot allerlei streken*), waarmede ik echter mijn voordeel deed.

*) De gesehiedenis dezer jengdige streken was bijna vergeten, toen zij, omstreeks 30 jaar later door een' tijdgenoot en Collega, deu thans orerleden hoogleeraar der ehemie, VAN DER BOON MESCH, in den vorm van een' mij toegebraehten feestdronk, bij gelegenheid van een groot gastmaal, in alle bijzonderlieden werler opgehaald werd. De kennismaking met dezen geoefenden, en altijd slagvaardigen redenaar was op eene eigenaardige wijze ontstaan. Hij wilde eens bij BorÉ inliehtingen inwinnen omtrent een' vogel en een eekhoorntje, die beide uit Oost-Indië op spiritus angebracht waren. BoIÉ verklaarde de dieren in dien toestand niet te kunnen determineeren, maar verwees hem naar mij. Ik herkende den vogel voor den toen nog onbesehreven Basilornis, en iu het eekhorentje eene nieuwe soort. Zijn broeder, lhoogleeraar in de natuurlijke historie te Amsterdam, wien deze dieren behoorden, wensehte ze te besehrijven, maar verzoelt om nauwkeuriger inliehtingen. Zij moesten derhalve opgezet worden; maar alle werklieden verklaarden dit voor onmogelijk, daar de veeren en laren reeds dreigden uit te vallen, en Boré zelf, hoewel met zulke werkzaamheden zeer vertrouwd, twijgfelde aan het welslagen. Ik daeht er anders over, vroeg de dicren tot nader onderzoek, zette ze binnen weinige uren op, hetgeen uitstekend uitviel, en stuurde ze vergezeld van eene latijnsehe beschrijving aan den brenger terug. De man was buiten zieh zelf van vreugde en vertelde van mij wonderen, hoewel ik hem verzekerde, dat er niets aan was, daar ik gewoon was, door vroegtijdige oefening, methode, en uit vrees voor tijdverlies, meehaniseh werk zoo spoedig mogelijk af te maken, dat ik bovendien den vogel reeds van nit het Weener Museum kende, en dat het eekhorentje zielı van alle andere bekende soorten door zijne opvallende kleur onderseheidde. Het hielp eehter niets, en toen ik, op verzoek van Temminck en BorÉ, en door alle praeparateurs omringd, een' versehen, kleinen vogel in 20 minuten gevild en opgezet had, werd mijn bewonderaar nog enthusiastiseher en verzoeht, dat dic vogel in de verzameling van het $\mathrm{Mu}$ seum moeht bewaard blijven, waarin hij inderdaad nog heden staat, en wel, met uitzondering van den Basilornis, als de eerste en eenige vogelhuid, die ik ooit in I.eiden gepraepareerd heb. Ik hoorde nu verder niets van die nieuwe dieren, totdat mij ongeveer een jaar later genoemde hooglecraar ten huize vall den heer REinwakDT werd voorge- 
Ik had met mijn' kamerbuur, den frjeschen Graaf v $\Lambda N$ Limburg StrRum, innige vriendschap gesloten. Hij was een edel, hoogst onbaatzuchtig man, die mij later, als burgemeester der stad en curator der loogeschool, vooral in de $\mathrm{Mu}$ seumkwestie, groote dienstell heeft bewezen.

Tịdens eene soirée, vertelde men mịj, dat de beste manier om hier te lande naam te maken was, eene door eene Hollandsche Maatschappij uitgeschreven prijssraag te beantwoorden.

Ik' 'merkte op, dat ik wel lust had zulk een' arbeid te oudernemen, maar niet vau plan was meer dan 14 dagen er aan te besteden. Zooals het toen mode was, volgde op dit vermetel gezegde onmiddellijk het voorstel eener weddingschap om oesters en eene fijne flesch. Ik nam ze aan, var STIRUM hield contrôle, en sloot mị in zij̄ne kamer op. Het boek was op den bepalden tijd gereed, en werd zelfs met den dubbelen prijis bekroond. Dit was mijne verhandeling over »het trekken der vogels". Bij den feestdisch begroette men mij, naar toeumalig gebruik, als »homo bislaureatus." Maar toen een van de gasten zich de opmerking ontvallen liet, dat bekroningen wel eens van het toeval afhingen, verklaarde ik mij bereid eene tweede prịjsvraag op dezelfde voorwaarden te beantwoorden, en op deze wijze ontstond mijne verhandeling over het sroeden van den koekoek".

$\mathrm{Bij}$ eene andere gelegenheid, toen het leeren van talen ter sprake kwam, opperde ik de meening, dat men, na zekere

steld. Hij vertelde mij, dat hij de besehrijving van dic nieuwe dieren gemaakt liad, en wensehte die aan mijn oordeel te onderwerpen. Tot mijne verbazing las hij mij nu woord voor woord mijne eigen besehrijving voor. Ik wreekte mij door ze bovel alle mate te prijzen, het treffende er in te releveeren, en hem als een geoefend Zoöloog te begroeten. Hij heeft ze in de Vorh. van het Kon. Ned. Instituut der Wetenseh. onder zijn' eigen naam laten plaatsen.

Men kan nagaan hoe amusant deze seene was voor do andere aanwezigen, die in het geheim der zaak ingewijd waren. 
voorafgaande studiën, binnen vier weken voldoende Italiaansch leeren kon.

Alweder eene weddingschap. De uitspraak der taal kende ik reeds, en hare spraakkunst had ik bestudeerd. In mijn' vrijen tijd leerde ik nu gesprekjes van buiten, en lietik elken avond, van zeven tot tien, een' beschaafden, jongen italiaanschen schoorsteenveger bij. mij komen, met den uitdrukkelijken last, niets anders dan italiaansch met mij te spreken en te lezen. Vier weken later kwamen de vrienden met een' hier ter stede woonachtigen italiaanschen koopman bij mij. Na een levendig gesprck liet ik hem Arrosto opslaan, en verzocht hem eenige Stanza's daaruit voor mij te vertalen; de man bleef echter steken: ik hielp hem voort, maar ten laatste verklaarde hij gemelijk, dat ik beter italiaansch verstond dan hij. Hij had trouwens, even zoo min als de toehoorders, er aan gedacht, dat het verstaan van poëzie iets geheel anders is dan dat van proza.

De nu volgende aardigheid had langer nasleep dan de voorafgaande. De beroende fluitist Drouet baarde toen ter tijd in geheel Europa zeer veel opzien door zijn zoogenaamd "Dubbeltongslagspel", voornamelijk in zijne variaties op de aria » Di tanti palpiti". Ik verklaarde, dat dit een gemakkelijk na te bootsen kunststukje was. Alweder eene weddingschap. In mijnc jeugd had ik iets van de theorie der muziek en het fluitspelen zouder leermeester geleerd, eigenlijk ter wille van de nagedachtenis van FrederIK DEN GRootE; maar het instrument, als te onvolkomen, reeds lang ter zijde gelegd. Zelfs het voorbeeld van Füinstuvau, van wien ik trouvens in Dresden veel afgeluisterd had, kon mij niet bewegen met zulk een amusement mijn' tijd te verbeuzclen. Maar nu schafte ik mij eene fluit aan; de aria werd gemakkelijk van buiten geleerd, de dubbele tongslag gelukte van zclf, en maakte vecl effect, te meer daar ik mij een' schoonen toon, vooral in de laagte, eigen gemaakt had. Men verlangde $n u$ het geheele stuk ook in ruimeren kring te hooren. Ik zette mij aan 't werk, liet het voor orkest 
zetten, en had de onbeschaamdheid, het in een openbaar concert voor te dragen. $\mathrm{Na}$ deze proeve verlangde men andere; ik werd weldra een gewild fluitist, en spoedig die laffe Inanier van voordracht moede, waagde ik mijj aan de voordracht der concerten van FürstevaU. Tegelijker tijd cchter, werd ik, ten einde wezenlijk nut van de muziek te hebben, lid van het orkest ell het koor; maar ik liet alles weer loopen, toen ik mijn doel bereikt had om, door medewerking bij, talrijlke uitrocringen, de geheele reeks van beroemde symphonieën, ouvertures, oratorio's ell koren in hun inwendig samenstel te leeren kennen. Later echter richtte ik in mijn huis eene zangvereeniging voor klassieke muziek op. Wij kwamen tot eenige openbare nitvoeringen in de concertzaal en in de kerk, maar alles loste zich ten leste op in de muzikale en litteraire soirées, waarbij ik de meerbeschaafden uitnoodigde. Tot oefening schreef ik intusschen van tijd tot tijd stukken voor de muzikale nieuwsbladen.

Ik had dadelijk, na mijne aankomst tc Leiden, de studie der kruipende dieren nevens die der amphibieën opgevat. Ik trachtte mij ten eerste met het groote materiaal in zooverre vertrouwd te maken, dat het zich volkomen in de oogen mijns geestes afspiegelde. Ik teekende alles wat merkwaardig was, deed zooveel mogelijk ondcrzoekingen op het skelet, vervaardigde eene geheele reeks praeparaten van de zachte deelen, en poogde bij voorkeur licht iu het duister gebied der slangen te brengen.

Door den belgischen opstand in het jaar 1830 werden echter alle - werkzaamheden afgebroken, vooral sinds ik mij in het corps der vrijwillige jagers van de Leidsche hoogeschool had laten opnemen, en weder in het soldaten-handwerk van 1813 en 1815 terugleefde. In het reld was weinig gelegenheid voor wetenschappelijken arbeid. Ik maakte mij dien tijd ten nutte door de metriek der ouden nawkeurig te bestudeeren, en mij in het nabootsen van allerlei dichtvormen to oefenen. 
Bovendien richtten wij een mannenzang-quartet op, waarbij ik de basstem zong.

Bij mijne terugkomst in 1831 rond ik voN SiEBold, den bekenden reiziger uit Japan, en Horrmass, den later zoo beroemd geworden kenner der Japansche taal. VoN Siebold was een man der wereld, maar tevens een onvermoeid arbeider, grootsch in zijne beschouwingen en, zooals het een' reiziger past, van rijke encyclopedische kennis voorzien. Wij begrepen elkander, en weldra ontstond er een dagelijksch verkeer in zijne woning. Daar viel veel te leeren. Door heun werd een geheel nieuw licht over het uiterste Oosten der Aziatische wereld geworpen; hij voerde langzamerhand vele honderden levende planten en boomen uit Japan in Europa in, die thans onze tuinen, ja zelfs ons landschap sieren. Proeven werden genomen omtrent den invloed van ons klimaat op deze planten; en knappe teekenaars verlevendigden als het ware het groote getal van nieuwe voorwerpen. Het bezoek van vele merkwardige mannen, waaronder ook de geograaf Rutrer, voN Bär, Robert Brown en Martius, verschafte mịj gewichtige kennismakingen; ethnographische beschonwingen drongen zich bij mij op, toen na de door Reinmalzid medegebrachte Dajakkers, nu Negers en Negerinnen van de Goudkust volgden, en Siebold een' Chinees en een' Maleier bij zich had; want niet zoozeer het bloote zien, maar de dagelijksche omgang gedurcnde verscheiden jaren, maakte de studie van die lieden vruchtbaar.

Toen vox Siebold mij het plan tot de uitgave van eene Fauna Japonica voorsloeg, nam ik de bewerking der gewervelde dieren, met uitzondering der Zoogdieren, die Tемminck zich voorbehield, op mij. Dientengevolge verscheen het eerste decl van dit werk, de Reptilia en Amphibieën bevattende, reeds in het jaar 1833. De bewerking der vogels viel mij zwaar; want hoewel Temminck, behalve wat aangaat de bovengenoemde afdeeling, zich verder in het geheel niet oin het boek bekommerde, terwịl dit mede onder zijn' naam verscheen, sloot hij toch zorgvuldig het voor de bewerking 
benoodigde materiaal weg, zoodat ik het slechts ouvolmaakt en stukswijze uit zịjne handen kreeg.

Hịj had bovendien eene zeer zonderlinge manier om het gebruik der vogelverzameling te belemmeren, daar hij de kasten liet toeplakken, onder voorwendsel daardoor de verwoestende insekten buiten te sluiten, hoewel dit, zooals ik hem voorspelde, en het vervolg het ook bewees, juist het middel was om aan deze diertjes gelegenheid te geven hun' verwoestenden arbeid rustig te volbrengen. Aan den anderen kant was hij tegenover vreemdelingen dikwijls uitermate vrijgevig, zooals dit b. v. uit de werken van BONAPARTE en Hartzaub op de reusachtigste wijze blijkt.

Onder deze werkzaamheden voltooide ik mịjn slangenwerk, waarmede ik meer dan tien jaar bezig geweest was. Van den beginne af had ik veel last met mijne teekenaars gehad; slechts een van hen, namelijk Dr. Mut.oER, die zelf zoöloog was, maar eerst later optrid, en ons te vroeg door den dood ontrukt werd, behoorde tot de uitzonderingen.

Ik besloot daarom de platen voor mijn werk zelf te vervaardigen en ze, om tijd te sparen, zonder voorafgaande schets, dadelijk op steen te teekenen, wat bij slot van rekening juistere nitkomsten opleverde en minder tijjdroovend was dall het nagaan van in het vak onbedreven kunstenaars.

De terugkomst van mijne oude vrienden SAL. MüLLIn en Korthals, door hunne reizen in de Oost bekend, de eerste voornamelijk als zoöloog, de tweede als botanicus, gaf een' nieuwen prikkel.

De regeering liet welhaast de uitgaaf van het bekende werk over onze 0 . I. bezittingen voorbereiden. $\mathrm{lk}$ werd met de bewerking der gewervelde dieren belast, waarvoor S. MüLLER zijne vele en onschatbare, in Indië gemaakte, waarnemingen beschikbaar stelde. Doch anderen hadden zich omtrent het plan van het boek bij de regeering weten in te dringen, en wij moesten toezien hoe op den titel, ja zelfs in de voorrede, verschillende personen prijkten, die met den inhoud van het werk ook niet het geringste te doen 
hadden gehad, en waarvan sommigen zelfs hinderlijk of verderfelïk geageerd zouden hebben, indien zij niet eene gestrenge terechtwijzing van mij halden ondervonden. S. MüLLER's geographische en ethnographische werken zijn buitendien van hoog gewieht; hij gaf ons voor het eerst een getrouw beeld van den Dajakker en bewoner van de binnenlanden, alsook van de kust van Nieuw-Guinea, en leerde ons, wat wij trouwens reeds aan den lier levenden Dajak opgemerkt hadden, dat dit volk met de bewoners van Celebes zich aan den polynesischen stam aansluit.

Ik moet hier de autobiographie mijns vaders een oogenblik afbreken, om eenige gebeurtenissen uit zijn bijzonder leven op te halen, die hij daarin niet vermeld heeft*).

Reeds in het jaar 1831 had hịj kennis gemaakt net müne latere moeder ConNej,IA Buddingh', de dochter van een' predikant aan de Kaag, die destijds met hare moeder op de Papegracht woonde. Zij waren in zekeren zin buren, daar mijn vader destijds ook op de Papegracht woonde, en haar huis dagelijks voorbij moest als hij naar het Museum ging. Het was een lang engagement, en mijn vader besteedde dien tijd met de opleiding en vorming zijner aanstaande, die niet in de gelegenheid was geweest eene meer dan middelmatige opvoeding te genieten. Hij leerde haar niet alléén vreemde talen, muziek en teekenen, maar wijdde haar in. alle natuurwetenschappen in, waarin zij weldra zoo thuis werd, dat zij later aan de geleerde gesprekken, die ten huize haars mans plaats hadden, met gemak deel nemen kon. In den herfst van het jaar 1835 liet hij haar eene reis naar Kopenhagen maken, waar zij gedurende twee maanden bij

*) Zijne autobiographie moest tot inleiding van zijn posthuum werk: "Forsehungen in den Gebieten der Land- und Völkerkunde, der Geselichte und Naturgesehiehte" dienen, en bevat daarom alleen de geschiedenis zijner wetenschappelijke ontwikkeling en loopbaan. 
de familie Melchiou gastrrij opgenomeu en overal op de feestelijkste wijze onthaald werd, zoodat zij nog iu later leeftijd met de grootste opgewondenheid over het deensche volk sprak. Van daar reisde zij over Berlijn en Leipzig naar Altenburg, waar zij tot Augustus 1836 bịj de ouders van haar aanstaanden echtgenoot bleef logeeren. Zij sprak dan ook duitsch, fransch en engelsch met de meeste gemakkelijkheid, vervaardigde zelve tooneelstukjes, die wij, hare kinderen, op eene poppenkomedie vertoonden, of ze zelven speelden, _zong zeer goed en speelde goed piano. Zoolang zijj leefde was zij niet alleen de guede genius mïns vaders, maar door haar tact om menschen te outvangen heeft zij niet weinig bijgedragen tot den europeeschen roep van gezelligheid, dien het bescheidene huis mijn vaders op de Vliet genoot en waar, in den loop der jaren, al wat naam in Enropa had een langer of korter bezoek placht te brengen.

Gednrende den loop van den zomer van 1836 begaf mijn vader zich naar München, nadat hij geregeld des zomers reeds vroeger reizen naar Zwitserland, Parijs en Berlijn had gemaakt. Omtrent München schrïft mịjn vader in zijne autobiographie: »Een langer verblijf in laatstgenoemde stad werd aan de kunst, hoofilzakelijk de bouwkunde, gewijd."

„Voor eene der grootere reizen" zegt Schleger verder, had zich een fijı en beschaafd man, tevens een kundig kenner der muziek, Baron Huysen van KaTTENDIJKE, bij mij aangesloten. Wij waren reeds in het veld vrienden geworden, en uadat de veldtocht geeindigd vas, deelde ik eene poos lang zijne kamers met hem. Hij was een man vrij van rooroordeelen, maar zeer gesloten, van helder inzicht, groote matigheid en streng ordelievend, en met wien ik tot aan zijn' ongelukkigen dood eene roortdurende vriendschap onderhield. Ik maakte weldra keunis met zijn' vader, den toenmaligen Hof-intendant en lateren Minister van Buitenlandsche Zaken, die zich door het oprichten ler voortreffelijke hofkapel zoo verdienstelijk gemaakt heeft, en sloot ook een' nauweren rrieudschapsband met den jongeren broeder van mïn' vriend, den 
lateren Marine-Minister, die eveneens een degelijk mnziekkenner was, en veel van zijne zeereizen in allerlei werelddeelen wist te vertellen."

Den 22en Juni van het jaar 1837 trad mijn vader cindelijk in den echt met zijne bruid Conxelia Buddirgh' met welke hij eerst op de Langebrug in Leiden bleef wonen. $\mathrm{Na}$ de geboorte zijner oudste dochter Cécilia, die daar den 26en April 1838 het levenlicht zag, verhuisde hij echter naar buiten, in een zijn' zwager toebehoorend huisje op de Marendijk*) buiten de voormalige Marepoort. Daar schonk hem zijne vrouw nog drie zoons: GustaAp (geb. 30 Sept. 1840 †)), Rudoly (geb. 24 Mei 1842, gest. 26 Juli 1844) en Leandeir (geb. 2 Febr. 1844).

Kort na de geboorte van laatstgenoemden, keerde hij naar Leiden terug en kocht een huis met een' grooten tuin op de Vliet, welk huis jarenlang het vereenigingspunt werd van alles wat in Europa wetenschappelijken naam droeg. De tijd, die niet aan de studie besteed werd, werd aan de kunst, voornamelijk de muziek gewijd, terwijl hij de oproeding zijner kinderen geheel op zich nam, en zoowel zijne dochter Cécilia als zijn' zoon LeEander tot degelijke musici vormde.

Ik zelf, die van mijn' vader het talent voor de teekenkunst geërfd had, wilde schilder worden, maar destijds was de schilderkunst eene broodelooze kunst, en mijn vader kon niet voorzien, dat dertig jaren later die kunst weder eene der best betaalde zoude worden. Hoe ongaarne dan ook, moest ik van mijn lerensplan afzien, en eene wetenschappelijke carrière kiezen.

In het jaar 1838, schrijft Schlegel, verder, werd mijne aandacht, door de herleving der valkenjacht in de omstreken

*) Dit huis is door den lateren eigenaar WILLuNK gesloopt.

†) Preeies 14 jaar later op den 30 Sept. 1854 schonk zij liem nog een doehtertje BETsr, dat eehter sleehts éen dag leefde. 
van het Koninklijk lustslot »Het Loo", op deze bijkans geheel vergeten kunst gevestigd.

Zij was vroeger reeds het onderwerp der gesprekken geweest, die ik met een' mijner oudste vrienden, den opperhoutvester en inspecteur-generaal der jacht in de Nederlanden, Verster vat Wulverhorst, hield. Deze, in het huis van zijn' oom Baron MeERMan opgevoed, en die zijne vorming aan diens groote bibliotheek te danken had, had zijne volstrekt eigenaardige beschouwingen bewaard, en was, gerugsteund door eene zeldzame gave, zoo diep in het wezen van alle menschelijke kennis doorgedrongen, dat hij, ook buiten zijn vak, hetwelk hij met duitsche grondigheid kende, in elke andere betrekking zeker een man van beteekenis zoude geworden zijn, indien lijj er niet de voorkeur aan gegeven had, om, door de vrije natuur omringd, het menschelijk leven van verre te bestudecren, ten einde zijn' bijtenden spot en ontkennenden geest, in een geheel Mephistophelisch karakter, den vrijiın loop te kunnen laten*). Onze gemeenschappelijke jachten werden gekruid met allerlei, trouwens zeer onschuldig bedoclde, prijzende of lakende gesprekken over het recht en onrecht, dat op het veld der wetenschap gepleegd wordt. Op zijn verzoek publiceerde ik in 1854 eene schets daarvan in het Jaarboekje van den Amsterdamschen dierentuin onder den titel "De wolf onder de schapen", met den hamer uit mijn wapen als ondertekening. Maar het stukje werd niet of verkeerd begrepen, zelfs door diegenen, die er den sleutel van bezaten, en dit lot viel ook soortgelijke later volgende brochures ten deel.

Met het oog op het Schillersche gezegde: "die Welt ist volkommen überall, wo der Mensch nicht hinkommt mit seiner Qual", had mijn vriend in eene eenzame dninstreek eene kraaienhut laten bouwen en hij gevoclde zich daar, evenals ik, zoo gelukkig, dat hij eens in zekere richting, waar

*) In de "Wolf onder de Schapen" heeft mijn vader zijn' vriend Verster breedvoerig geschetst. 
geen dier, maar slechts een enkel man te zien was, zijn geweer op dezen aanlegde, omdat deze hem te midden van het grootsche schouwspel van eene nocli ongerepte natuur, storend in den weg stond. De man verdween onmiddellijk, en mijn vriend reciteerde mij toen alle op de omstandigheden toepasselijke passages uit den Faust van Göthe, dien hij op zijn duimpje kende. Dit waren echter slechts verpoozingen tusschen erustiger bezigheden en beschouwingen.

Vóór alles de natuurwetenschappen genegen, liet hij in vele plaatsen in het duin, en op verschillende diepten, boomen en struiken planten, ten einde de voor elke soort noodige levensvoorwaarden te leeren kennen; maar het resultaat was, dat deze voorwaarden als door een wonderlijk toeval voortgebracht schenen en niet onder bepaalde wetten te brengen waren. Wijders liet hij zoutwater-vijvers graven en plaatste daarin vissche'ı van de meest onderscheiden soorten, voornamelijk ook zoutwatervisschen. De zoetwatervisschen tierden en vermeerderden zich verwonderlijk, maar de zeevisschen plantten zich niet voort; zij groeiden zeer langzaan, hunne kleuren verbleekten en hun vleesch smaakte flauw.

Een nog merkwaardiger verschijnsel werd waargenomen uadat, in een' omtrek van verscheiden uren, de overal in het duin voorkomende grijze wouw (Circus cinereus) uitgeroeid was.

Sinds dien tijd, nu circa dertig jaren geleden, heeft zich daar geen vogel van deze soort weder laten zien; hoewel hij tot aan de grenzen van die streek, evenals vroeger nestelt. Bovendien deelde hij mij eene menigte warnemingen over allerlei dieren mede, en het museum heeft aan hem, evenals aan zijn' zoon, den tegenwoordigen administrateur van het museum, een zoo groot aantal en eene zoo fraaie reeks van rogels te danken, als slechts zulke kenners en schutters, vergezeld van flinke jagers en in eene zoo gunstig gelegen localiteit wonende, konden samenbrengen.

Mijn vriend had reeds vroeger eene kleine verhandeling over de valkenjacht gepubliceerd. 
Wij vatten de zaak weder op, en begaven ons naar het Loo, om bij deze jachten tegenwoordig te zijn. Van toen af herhaalde ik dit bezoek alleen en bijkans jaarlijks, en bestudeerde in Valkenswaard, de zoo beroemde bakermat en leerschool van alle valkeniers, het vangen en africhten van de roofvogels. De kenmis hiervan scheen mịj te belangrijker toe, omdat het zaak was de ware geheimen van eene kunst, die nu als zoodanig in Europa geheel vergeten is, aan de bron na te sporen, en omdat zij mij de gelegenheid aanbood de juiste geschiedenis van een gebrnik, dat vroeger gedurende verscheidene eenwen zulk eene voorname rol gespeeld heeft, en belangrijkke wenken voor de geschiedenis van verscheiden volken aanbiedt, aan het licht te brengen. Op deze wïze ontstond het groote »Traité de Fanconnerie" welks titelblad ook den naam van mijn' vriend draagt. De uitgaaf van dit werk werd bovendien voor mij zeer belangrijk, omdat zij tot de ontdekking van den onovertroffen dierschilder WoL, leidde. Kaup, zelf een geestig teekenaar en kunstrechter, bracht mij het schetsboek van den toen nog zeer jongen kunstenaar, die zich, zonder eenige leiding, zelf gevormd had, maar geene positie kon verwerven, omdat men de verblindende werken van Gousp boven zijne voortbrengselen stelde. Ik herkende terstond de buitengewone portée van zịnn talent, en mịne eigene worsteling in vroeger jaren indachtig, haalde ik mijn' uitgever A. AnNz over, WoLf naar Leilen te laten komen, en hem zoodoende de gelegenleid te rerschaffen vasten voet op zijne kunstenaarsloopbaan te krïgen. De platen der jachtrogels, die hij hier voor nuijn werk vervaardigde, zijn altijd nog het volmaaktste, wat ooit in deze en aanverwante takken der wetenschappelijke kmst gewrocht is.

Gedurende die jaren had ik mij roor langeren tijd naar Dusseldorf begeven, ten einde de daar aanwezige schilderschool te bestudeeren. I $k$ vond overal, vooral ten huize van 
ScIIAdow, eene vricndelijke ontrangst, maakte kemnis met Lessing en Achenbach en knoopte betrekkingen met HuldeBRAND aan, wiens technische studies in de schilderkunst zeer belangrijk voor mij warell, terwijl aan SonderLand reeds vroeger de vervaardiging der platen van het valkenwerk was opgedragen. Het huis en de tuin van de beminnelijke familie Ansz, wier gast ik was, vormden toen ter tijde het middelpunt, waar zich de kunstenaarswereld, alsook vele ruerkwaardige en aanzienlijke mannen, vereenigden. Het instituut van Anvz was toen in vollen bloei, en zoodoende bood alles mij overrijke stof tot uitbreiding mijner kennis. De wrïving, die in den regel tinsschen kunstenaars en geleerden omtrent de uitroering van wetenschappelijke teekeningen plaats heeft, gaf anleiding tot mijne verhandeling over dc eischen van dergelijke afbeeldingen, en de concessies, die de knnst ten gunste der wetenschap doen kan. Dit werk werd door Teylen's Genootschap, in welks werken het opgenomen werd, luet de groote gouden medaille bekroond.

Omstreeks dien tijd kwam Charles Lucien Bonaparte, Prins van Canino, щuar Leiden. Ik had reeds twintig jaren vroeger kennis met hem gemaakt en deze door herhaalde briefwisseling ouderhouden. Deze nierkwaardige man vond met het grootste gemak den rechten weg in de grootste diepten der wetenschap, door zijn' alles radenden blik en eene tot overdrijving opgevoerde werkzaamheid. In de hoogste mate aangenaam in den omgang, een kindervriend *)

*) Nog heden herinner ik mij nit mijne kinderjaren dezen beminnelijksten van alle vorsten. Hij kwam nooit ten onzent zonder iets voor de kinderen mede te brengen, en $\mathrm{kreeg}$ eens de tranen in de oogen bij de vertooning vin een ehineesch schimmenspel, dat hem zijne eigene jeugd, en die zijner kinderen in heriunering bracht, van welke hij door zijne ballingsehap verwijderd gehouden werd. Hij noodigcle in $155 \mathrm{t}$ mijne ouders met ons uit om naar Parijs te komen, 
zooals weinigen, en in den kring der familie, de beminnelijkste en vertrouwelijkste mensch dien men zich denken kan, was hij daarentegen in de politiek wat de Franschen een » farouche républicain". noemen. Maar hij was het slechts

en ik sehreef hem een' brief om hem te danken, hoewel omstandigheden mijn' vader destijds verhinderden deze uitnoodiging aantenemcn. Een paar dagen later ontving ik, toenmaals een veertienjarige knaap, een' eigenhandigen brief van del prins waarvan ik hier den aanhef mededeel, omdat hij toont welk een walm kindervrieud hij was.

"A la boune hewre, mon eher petit ami, ta lettre du moins est de celles qui eonsolent; la bonne lettre de ta Maman m'avait laissć peu d'espoir et celle de ton pòre me l'avait enlevé tont-ì-fuit. C'est si vrai que j'avais presque ec̀dé ‘̀ l'insistanee de mes médeeins, qui ne saehant plus que faire, veuleut absolument m'envoyer aux eaux malgré la saison. Mais votre soeiété me fera beaueoup plus de bien que les douehes d'eau minérale. Tu vois cependant qu'il est néeessaire que je saehe positivement à quoi m'en tenir. Ne me laissez done pas plus longtemps dans l'ineertitude. Il est bien entendu que non seulement CÉCILE (mijne zuster) mais vous tous iriez à l'opéra et dans beaueoup d'autres théâtres et endroits délieieux dont vous ne soupçonnez pas même l'existenee et qui ne se trouvent qu'à Paris. Oui, mon eher Gustave, je m'engage, tout en vous proeurant des oeeupations sérieuses et iustruetives, à vous faire amuser beaueoup et Maman aussi. Quant ¿̀ Papa soyez persuadé qu'il ne perdrait pas son temps sous aueun rapport. .. Thans volgen nog eenige vragen vau wetensehappelijken aard aan mijn' vader, en de brief sluit met de woorden:

"Je vous embrasse tous comme je vous aime, en attendant que je puisse le faire en réalité.

\section{à toi de coeur}

\section{L. BonapartTE.}

Deze brief, dien ik steeds heilig bewaard heb, is uit Parijs den 14en November 1854 gedateerd, en was gedresseerd aan:

Monsieur Gustave Schleged, ćtudiant en Chinois ì Leyde.

BoNAPARTE wist, dat ik toen eene munt- en zegelverzameling had, en daarom had hij ziju' aan mij geriehten brief opzettelijk met een' zeer zuiveren afdruk van zijn eaehet verzegeld.

Zijn welgelijkend portret, dat hij "à son ami et eollègue H. SCHLEGEL” sehonk, hangt thans in mijne stuleerkamer, tot blijveude herinnering" aan een' man, die, hoe hartstoehtelijk ook, steeds cen onbedorven, kinderlijk gemoed bewaard had. 
met den mond en niet in zijne daden. Te goed van vertrouwen en te goedhartig, werd hij de prooi zijner eigen partij, die hij in stand had gehouden, en voor welke hij, om liare eer te redden, een aanzienlijk gedeelte van zijn vermogen opgeofferd had, zonder iets anders dan ondankbaarheid daarvoor te oogsten.

Hij wilde dit echter niet inzien, en hechtte gecn geloof aan de bewijzen die ik hem voorlag. Dit legde mij het stilzwijgen op; maar toen hij eens hier in het land door cene trouwens treurige deputatie van die republikeinen een bezoek kreeg, cu hij mij uitnoodigde den avond in hun gezelschap door te brengen, konde ik mij miet onthouden het bij eene dergelijke gelegenheid door den kamerdienaar van den regent Philip vax Orlieans gegeven antwoord: "pardon, Monseigneur, je ne vais pas cn si mauvaise compagnie" te herhalen, en er nog bij te voegen: "et je regrette de vous y voir".

In zijue vrije uren was hij vroolïk en opgeruimd, vergat rijn noodlot en klaagde hoogstens over de vele vijanden die hij had, zonder te begrijpen, dat hị zelf zijn grootste vijand was. Gedurende onze wandelingen liep het gesprek meestal over de wetenschap; maar tot afwisseling sprak hij wel eens over wat anders, ging tot het koddige over, zong met de hem eigene, treffende en geestige, voordracht een parijsch straatdeuntje, om zich dan weder plotseling op zijn geliefkoosd droombeeld van eene algemeene republiek te werpen. Ik liet hem begaan, maar daarmede was hij niet tevreden en vroeg mij mijne meening af. 1k zeide hem, dat ik niets tegen eene republiek had, als zij maar als een goed uurwerk liep en krachtig was. Mịne bewijsgronden waarom deze regeeringsvorm in Europa nog niet bloeien kon, trachtte hij door de wachtspreuk: "vous êtes done blane comme la neige" omver te stooten. En toen ik hem antwoordde: "cela vaut toujours mieux que d'être rouge comme du sang," zweeg hij, zooals gewoonlijk als hem iets niet beviel. Toen ter tijde zou niets hem bewogen hebben om, zooals hij later 
deed, onder eene antocratische regeering, zooals die van zijn' neef Napolios III, te leven, van wien hij, evenals van ziju' oom te Parijs schriftelijke aanzoeken om voorschotten toonde, als ook het eigenhandig bewijs van den anderen oom, dat niet hij, die 15 maanden lang van zịjne familie verwüderd was geweest, maar VErHubLL de wezenlijke vader van den neef was*). Ik heb van deze zaak nooit een enkel woord gerept, en zonde het ook thans niet doen, zoo zij niet, daar zij ook aan anderen toevertronwd werd, reeds eenigszins verbreid was geworden. $\mathrm{Zij}$ behoort tronwens tot eene juiste waardeering der geschiedenis van die mannen en dien tijd.

Bonaparte werkte bijkans een jaar in mijne kamer; wij schatten elkander hoog; ik koesterde voor hem eene warme vriendschap, en nog kort voor zijn niteinde $\dagger$ ) riep rij, zooals een der omstanders mij schreef, nit: »SchLEgEL was mijn liefste vriend".

In den beginne verdiepte hij zich geheel en al in zijp' "Conspectns der gewervelde dieren". Toen ik hem deed bemerken, dat hï door zijne onafhankelijke positie, de onbelemmerde beschikking over zijn' tijd, en door zijn' fortuin, meer dan iemand anders in staat was een overzicht, verzeld van diagnosen, van alle vogelsoorten te geven, een arbeid waaraan zich sinds LАтнАM niemand gewaagd had, ontwierp hịj dadelijk een nieuw plan voor zijn' "Conspectus arium", met de woorden: "U behoort de gedachte toe, en dus ook de dedicatie". Bonaparte had zich tot dien tijd bijna uitslnitend met de Noord-Amerikaansche, en als bijzzalk met de Enropeesche vogels bezig gehonden. Zooals vall zelf spreekt, onderstemnde ik hem naar mijn beste weten, en werd hij eerst toen meer terughondend, toen hijj mijn, door mijzelf nog niet getoetst, voorloopig oordeel zonder meer neerschreef en

*) Slrchts met moeite en nadat ik hem bewezen had, dat het toeh nicts helpen zou, hield ik hem er van terug deze brieven, toen zijn neef hem in de Parijsche kamer rerlooehende, openbaar te maken.

†) Hij overleed te Parijs den 28en Juli 1857. 
drukken liet. Zijne scherpzinnigheid liet hem echter weldra zijn' eigen weg vinden, waaraan ik trouwens niet altijd mïne goedkeuring hechten kon, maar die desniettcmin der wetenschap reel nut deed. Bij de studie der vinken, kwam de gedachte op om aan de roode diksnavels een boek te wijden, en zoo ontstond de "Monographic des Loxiens", die wij te zamen uitgaven, en voor welke ik de beschrijvingen en afbeeldingen leverde. Naar Parijs vertrokken, keerde hij eerst eenige jaren later naar Leiden terug. Hịj was toen reeds zeer lïdende, en zeide mij bij het afscheid : » wịj zullen elkander niet weêrzien, en ik verzoek U mijn grafschrift te maken." Ik deed dit, maar deelde het hem niet mede, daar toch levenden niet gaarne aan den dood herinnerd worden, en daar het ook slechts voor een boek past. Het is aan zijn leven en aan zịjn' geest ontleend en luidde: $\gg \mathrm{Ci}$ git Bonaparte, le naturaliste. Il mourut conıme il a vécn: en philosophe, la boutonnière vierge, et puisant la consolation suprême dans la contemplation de la nature".

Gedurende eene reis, die ik gemeenschappelijk met BorAPARTE maakte, vertoefden wịj ook eenige dagen bịj Prins $M_{\triangle X}$ vor WIED te Neuwicd. Ik had dezen voortreffelijken naturalist reeds zeventien jaar vroeger lceren kenuen, en was een bewonderaar van zijne nitnemende waarnemingsgave, van zijue juiste en ongekunstelde opvatting, van zijne eenvoudige en grondige wijze van voorstclling, van zijne waarheidsliefde en bescheidenheid. Zijue werken znllen steeds eene bron voor ware zaakknudigen blijven. Hịj naw, mecr dan vele andercn, het levendigst aandeel aan mijue werken, placht mij tot uitspanning een langer verblijf ten zijnent $\mathrm{cn}$ in zijne jachtgronden wan te bevelen, en onze briefwisseling dunrde tot ziju' dood.

In die jaren hield ik mij ook bezig met het onderzoek der Maastrichtsche fossiele Reptilia, waarvan ik uitvoerige teekeningen vervaardigde, die echter niet uitgegeven werden. 
Het een en ander daaromtrent staat in mijn' brief aan BionsPARTe, die in de "Comptes rendus" van de Parijsche Academie gedrulst is. Hij handelt over valsch bestemde beenderfragmenten vau den Mosasaurus, met het bewijs, dat dit reuzendier, evenals de Ichthyosaurus en Plesiosaurus van zwem- en niet van looppooten roorzien was.

Van de vele merkwaardige mannen, met welke ik in aanraking kwam, wil ik alléen nog CavaigNaC vermelden. Deze uitstekende generaal el staatsman, vall wiens edcl karakter een iegelijk en zelfs de meest wantrouwige zoo overtuigd moest zijn, dat men hem niet eens de eer der verbanning gunde, was een wetenschappelijk gevormd en ernstig denker. Hij verdiepte zich gaarne in de diepste vragen der philosophie, en daar mijne beschouwingen van die van Arago, met wien hij ze het liefst placht te bespreken, verschilden, nam ons onderhoud bij]kaus geen einde, en noodigde hij mij bij het afscheid uit, den jachttijd op ziju landgoed te komen doorbrengen. Wij vermoedden echter toen niet, dat een plotselinge dood den krachtigen man zoo vroeg zoude wegmaaien.

. Omstreeks dien tijd liet ik mij ook door een geleerd en bekend officier, den overleclen generaal St:TLitg, bepraten om een handboek del dierkunde*) te schrijven. Het was bestemd, zoowel voor het onderwijs aan de Kon. militaire Academie te Breda, als ook om nasporingen in ruimeren kring, vooral in onze koloniën, uit te lokken. In dit boek heb ik vooral mededeelingen, door strenge kritiek getoetst, betreffende de zeden en leefwijze der dieren, alsook de meest nauwkeurige, meestal door mijzelven, naar de natuur geteekende, afbeel-

*) Dit werk verscheen in 1857 to Breda. 
dingen gegeven. Mijn hoofddoel was de dieren, in plaats van ze, zooals gebruikelijk, naar enkele kenteekenen te schetsen, volgens hun geheele wezen te schilderen, en het systeem tot eene natuurlijke eenvoudigheid terug te brengen.

Ik moet hier ook nog van de inrichting van den Amsterdamschen Dierentuin, dic zulk eene mcrkwaardige vlucht genomen heeft, gewagen. De ziel dezer instelling is, zooals bekend, Di. Westermas. Met een' helderen, practischen blik, dicp inzicht, onvermoeiden jjver, de wetenschap bovenaan plaatsende, en als mensch tot de voortreffelijkste behoorende, werkt hij steeds scheppend; hij bevorderde de uitgaaf van verscheiden werken, het streven der gelecrden en het docl van uns Muscum, en arbeidde aldus het krachtigst aan den opbouw der wetenschap.

In genoemde diergaarde bevonden zich een zeker getal levende Turako's (Musophaga). Ik teekende ze, evenals de andere soorten uit ons Museum, in natuurlijke grootte naar het leven en de natuur, op steen, cn het Genootschap, met zijn' voortreffelijken Directeur aall het hoofd, stelde mij in staat, dit werk met gekleurde platen uit te geven *).

Ik had bij deze vogels het reeds vroeger door JULis VurREAUX waargenomen, hoogst vreemd, verschijnsel bestudeerd, dat de roode klẹu hunner vlengels, bij indompeling in water, uit de vccren verdween en het water rood klcurde, en dat zij, als zij droog geworden waren, weder rood werden. Ik ontdekte vervolgens, dat het rood der vleugels, als deze bij den dood der vogels vochtig gehouden werden, in blamw overging. Deze verschijnselen hadden voor mij des te meer gcwicht, omdat zij zich aansloten aan mijne nasporszen over de dikivijls, hoewcl verkeerdelijk, als ecn gevolg van de ruiing beschouwde kleurverwisscling en den vernieuwden groei van de oude rogelveercn.

Bovengenoemde verschijnselen moesten mijj tot andere beschouwingen als de heerschende over het vederkleed der

*) Uitgegeveu in 1860 (niet in den handel). 
rogels leiden, en verdienden wel een nader onderzoek dan dat hetwelk de ornithologen gemeenlijk dnaraan wijjen. Microscopisch onderzoek, dat ik herhaaldelijk en voortdurend naar dit verschịnsel bewerkstelligde, leidde, evenmin als dat van anderen, tot eene voldoende oplossing*).

Der Amsterdammer Diergaarle wijdde ik later ecn bijzonder werk met 300 af veeldingen, die volgens oorspronkelijke, naar het leven geschetste teekeningen in hout gesneden werden. Daarin vindt men, zooals het nu juist te pas $\mathrm{kwam}$, allerlei waarnemingen vermeld.

Het onderzoek van een zeker aantal olifanten leverde de volgende resultaten op. Ilk had reeds vroeger den olifant van Sumatra als eene bijzondere soort onderscheiden en mijne waarnemingen aan den Heer Tuminck medegedeeld, dic ze in een zijner werken publiccerde. Het bleek thans, dat de olifanten van Ceylon en Sumatra als soort niet van elkander te onderscheiden zijn; dat de Indische olifant tot Dekan, Siam en Malakka verspreid is, maar niet op die eilanden roorkomt; dat G. Cuvien de beide soorten gekend leeft, maar ze verward en niet onderscheiden had; dat cr waarschijnlijk eene tweede, afwijkende Afirikaansche soort bestaat; dat de vermindering van het getal ribben, tegelijk met de lengteas der tanden (gemcenlijk tandlamellen genoemd), in regelmatige volgorde van den Afrikannschen olifant tot aan den Mammouth plaats lieeft; en eindelijk, dat, ten gevolge dezer verschijnselen, de Mastodonten wel eene parallelle, maar niet eene doorloopende reeks der olifanten vormen.

*) Zie zijne verhandeling "Over don groei en de kleurverandering der vederen van de vogels (Versl. en Meded. Kon. Ac. v. Wet. 1. i853; Leber ch:s Fntstehen des vollkommenen Kleides der Vögel durch Verfärben und Wachsun der Federn, unabhängig von der Mauser (Naumannia Il, 1852); Ueber meine Verfürbungstheorie (Naumannia 1855). 
Ik meende toen (in 1854) ook met degelijke bewijzen te moeten optreden tegen de pogingen on den Dodo, naar aanleiding van eenige versehillen in zijn' inwendigen bouw, onder alle mogelijke orden der vogels te rangschikken, behalve onder die waartoe hij behoort, 11amelijk die der struisvogels, en waarbij hein de zeevaarders en LrNNaEus tereeht geplaatst hadrlen.

Zoodra ik hier aangekomen was, had ik mij voorgenomen het land, dat ik thras bewoonde, in zijn' geheelen onlvang nauwkeurig te leeren kennen, want alleen dat wat ons dagelijks omgeeft en wat men altijd opnieuw onderzoeken kan, kan licht in het duister der wetenseliap, hetzij van die der natuur of van de bewoners van het land en hunne geschiedenis, brengen. Ik zal later mededeelen hoe ik dit alles als één geheel opvatte; hier wrl ik alleen vermelden, dat ik naast de studie der Fanna, ook die vall den bodem en van de Flora in het oog hield, waarbij mij het aanleggen van een eigen herbarium van veel nut was. De besehouwingen in de vrije natuur, werd, behalve op de dagelijksehe wandelingen, eens in de week een geheele dug gewijd, en ik noemde dat inijne jachtdagen, omdat ik nijn geweer steeds bij mij had. PalLas en Cuvitr hadden steeds tot mijne lievelingsschrijvers behoord: hunne werken dienden mij thans als gids. Evenzoo die van Baster en SLABBER, die mij tot eene nauwkeurige studie der lagere dieren, hoofdzakelij]k betrekkelijk hun samenstel, leidden, ell waardonr het Museum met talrijke praeparaten verrijkt werd. Ik traehtte ook eene groote menigte visschen bijeen te brengen, maar ik hield mij bij voorkeur met de vogels bezig, omdat zij, uit velerlei oorzaken, de het meest in het oug loopende eigenaardigheden van eene fauna aanbieden.

Het was altijd mijne gewoonte geweest om schetsen van dieren naar het leven, dikwijls gedurende de jueht zelve, of in diergaarden te maken, en elk afzonderlijk deel, vooral 


\section{( 54$)$}

den kop met zijne uitdrukking, door karakterteekeningen terug te geven.

Langzamerhand was er op deze wijze, alleen voor mijn eigen genoegen en gebruik, eene groote menigte van zulke studies ontstaan. Herhaalde uitnoodigingen deze te publiceeren, sloeg ik af, omdat ik mij niet met het toezicht op zulk eene onderneming kon bemoeien. Maar toen Dr. Herkxors mij voorsloeg, zich met de zorg daarvoor te belasten, gaf ik mijne » Vogels van Nederland"*) uit, die, behalve den tekst, 362 platen bevatte.

Dit werk, hoewel voor velen te kostbaar, ondervond een' onverwachten opgang. In weinig jaren was de geheele oplaag uitverkocht. Buiten mijn weten, verscheen daarvan eene tweede, helaas veelvuldig ontsierde, uitgaaf. Mijne eenige voldoening is, dat de eerste editie van dit boek, als het toevallig eens onder den hamer komt, met het dubbel van den oorspronkelịjken prïjs betaald wordt, en dat het bij menigeen de liefde en den lust tot dit vak heeft opgewekt. Er waren echter ook anderen, die er in het geheel geen acht op sloegen, omdat zij niet eens in staat waren zulke werken te verstaan en te beoordeelen. Anders zoude men de tamme, kleingeestige en suikerzoete plaatjes, zooals b. v. die van de Iconographie van Cuvier's Règne Animal, niet zoo dikwijls, tot walgens toe, herhaald zien. Voor het overige was mijn werk in het buitenland wel nauwelijks bekend geworden

De wensch, eene volledige natuurlijke historie der $\mathrm{Ne}$ derlanden te bezitten, werd van nu af steeds levendiger en algemeener, totdat hij eindelijk door den beschaafden en wakkeren uitgever Knusbman te Haarlem op eene de zaak waardige wijze werd verwezenlijkt. Ik nam daaraan deel

*) Leiden 1854-1858. 2 ln. 


\section{('55)}

door de bewerking der gewervelde dieren, en bewerkte toen de natuurlijke historie der Nederlandsche vogels nog eens, maar op eene andere wijze. Men vat gewoonlijk, en het kan wel niet anders, de grenzen van eene Fauna in politieken zin op. Ik traehtte echter aan te toonen, dat juist ons klein landje een groot getal, onderling zeer verschillende fauna's bezit, zooals ook door de versehillende loealiteiten gevorderd wordt. Om dit duidelijk te maken, sehetste ik eene toepasselijke reeks van landschappen, gestoffeerd met de meest opvalleude vertegenwoordigers der vogelwereld, van iedere bïzondere localiteit. Op deze wijze ontstonden plaatjes, ontleend aan stad en dorp, weiland en heide, veld en bosch, riviermondingen en binnenwateren, aan de onderling zeer versehilleude duinstreken, wan het zeestrand in den zomer en den winter en aan de eenzame zee-eilanden. Voor het juist begrip der iedere soort kensehetsende physionomie, voegde ik bijj dit werk de daarbij behoorende, vroeger opgenoemde, naar het leven ontworpen, studies van vogelkoppen.

De Fauna van onze Oost-Indische bezittingen vereischte, en vereischt nog heden, eene grondige behandeling. Als eene proeve koos ik daarvoor de vogels; en ten einde het boek voor een elk bereikbaar ts stellen, gaf ik daarvoor afbeeldingen op de kleinst mogelijke schaal, maar voegde daarbij alle afwijkingen, noodig voor de eigenlijke kennis der soorten, nevensoorten en variëteiten. Maar omstandigheden van buiten kwamen storend in den weg, en het boek kwam niet verder dan tot de monographieën der indisehe Pitta's; IJsvogels eu Valkvogels*).

Voor de laatste alleen had ik 110 afbeeldingen noodig, die, evenals de andere, aan mïn sehetsbock ontleend werden, en het bewijs leveren, hoe zelfs in miniatuurplaatjes uit-

*) 1863-1864. 
voerigheid alsook de voorstelling van het ware karakter van elke soort te bereiken ziju.

Mijne werken over de Nederlandsche vogels hadden een' jong liefhebber der Nat. hist., FrançoIs Poluen, opgeweltt zich tot mij te wenden. Hij was voor eene andere carrière bestemd, maar, na ziju bezoek in Leiden, verklaarde hij, zich der wetenschap te willen wïjen. Zijn onvermoeide ijver, ondernemingsgeest, snelle opratting, gave van waarnewen cn onbegrensde liefde tot de zaak, deden mij besluiten hem eene reis naar Madagaskar voor te slaan, wel berroedende, dat hij buitendien, door het merkwaardige van de bouwstof gesteund, iets belangrijks zoude uitrichten.

Voor nijj was altijd groudige kennis van reeds beschreven soorten, vooral naar de juiste betrekking harer verspreıding, minstens evenveel waard als de ontdelking van nieuwe dieren, waarop meu meestal alleen uit is on zïne $\ddot{\mathrm{j} d e l h e i d}$ te voldoen.

Madagaskar biedt door zajne afgeslotenheid, door de plaatsclijke onderafdeelingen van zijne eigenaardige Dierenwereld, meer dan een ander deel der aarde, eene leerrijke stof voor het groote, nauwclijks in de grondslagen ontworpcu gebouw der Dieren-geographie. Vandaar mijne keus van dit raadselachtig land. YOLLEN trok, na behoorlïke voorbereiding, daarheen met het voorschrift, pas voor pas, in enkele streken de grootst mogelijke verzamelingen te maken. Na zijne terugkomst liet hij de begonnen onderneming, hoewel met onwillekeurige stakingen, door anderen, en zelf's tot Leden op zijue liosten, voortzetten, en leverde hierdoor het zeluzame voorbeeld val een' jongen man, die der wetenschap op onbuatzuchtige wijze zeer groote offers heeft gebracht. De geschriften, die hij uitgaf, getuigen van hetgeen hij gedaan heeft, en ik meende ze te moeten doen voorafgaan door de systematische beschrijviug der 'Loogdieren en Vogels. Llet was mij roorul daurom te doen, de soorten tot hare jusste quaniticit terug te brengea, en dais aan de miskende hare ware plaats in het systeem te geven: resulta- 
ten, die op liehtvaardige wijze aan anderen zijn toegesehreven, of die zieh anderen zelven nog tuesehrijiven. De bij het werk gevoegde afbeeldingen zijn voor het grootste gedeelte uaar mïne teekeningen gematat.

Een ander jong liefhebber, de teekenaar Keulemans, die op mijne aanbeveling den Heer DoHRN op zijne reis naar de eilanden van het groene voorgebergte vergezelde, en dien ik, na zäjnc terugkomst, aan het Museum verbonden en tot dierenteekenaar gevormd liad, volgde weldra het voorbeeld van den teekenaar SMr', dien ik evencens voor dit vak opgeleid had. Beiden verhuisden naar Londen, waar zij een' lucratieven werkkriug vonden.

De buitengewone toeneming der verzamelingen van het Museum moest tot den wensch leiuen, een gedrukt overzicht, dezer seliatten te bezitten. Catalogi, in den gewonen zin, geven weinig bat. Zooals in de geheele wctenschap, rijn bij zulke geschuiften alleen eritische monographieën doeltreffend, en het seheen mịj van bijzonder belang toe, om elk individu afzonderlijk aan te halen, zijne juiste herkomst, als ook des vereiseht, zijne eigenschappen en vermoedelijke eigensehappen te vermelden. Deze overwegingen gaven aanleiding tot de uitgave van mịjn »Muséum d'histoire naturelle des Pays-Bas", waarvan tot heden aeht deelen versehenen zijn. 'Zij bevatten het monographisch overzicht der apen en een aantal vogelgroepen, met de vermelding van ten naasten bij 20.000 voorwerpen.

Ik moet thans tot het jaar 1858 terugkeeren, het treurigste jaar mijus levens, het jaar waarin mijn levensdoel, eene der wetenschap, zooals ik ze opvatte, waardige inrichting te stiehten, op het punt stond sehipbreuk te lijden. 
Deze geschiedenis is treurig, en daarbij lang, en daarom voor den lezer, die ze niet overslaan wil, dubbel vervelend. Ik zoude er geheel en al overheen gestapt zijn, zoo zij niet op eenzijdige wijze aan het licht gebracht was, en mïn stilzwijgen diarover, en dus ik zelf, somtijds nog in den jongsten tijd, onjuist beoordeeld ware geworden. Ik schrijf ze $\gg$ sine ira et studio" met de grootste bedaardheid en overleg, met volkomen onpartijdigheid, zelfs de schaduwzijde temperende, het nog ergere verzwijgende; en zoude, als een geloorig Christen, ieder woord daarvan voor den rechterstoel des Allerhoogsten kunnen verantwoorden. De ware toedracht der zaak is de volgende: $\mathrm{Na}$ den dood van mïjn' voorganger*), wiens plaats ik reeds gedurende zijne langdurige ziekte met den administrateur der inrichting officieel had waargenomen $\dagger$ ) ontstonden er, ten gevolge van persoonlijke belangen, ondersteund door den partijgeest van een' zeer invloedrijk man, zeer beklagenswaardige en nuttelooze wrïvingen tusschen de Universitcit en het Museum. Het laatste, alhoewel eene zelfstandige instclling, moet der wetenschap in den ruimsten omvang, en derhalve ook, voor de uitverkorenen, aan de hoogcre Academische studiën dienstig zijn. Het moet derhalve ook in den kring der Universiteit staan; maar liet daarmede te vereenigen, zou gelijkstaan met zijn' levensdraad af te snijden.

Als een gevolg van het niet meer tc overzieue materiaal en de toevoeging van deu microscoop, moest echter reeds sinds lang het ondervijis der Academische jongelingschap beperkt worden tot eene uitvoerige behandeling van de grondtrekken dezer wetenschap, en de hoogere vragren, die zich aan de kennis der soorten knoopen, daarvan uitgesloten worden, te meer daar de dierkunde, met weinig uitzonderingen, voor de studenten slechts eene eenvoudigc hulpwetenschap is. Ieder leeraar moet dus, naar zijne eigene

*) Temminck overleed 30 Jan. 1858.

†) Kon. Besluit 17 Juni 1857, N.92. 
inzichten, eene bijzondere verzameling, de hoofdvormen van het dierenrijk en hun' bouw bevattende, voor zijn onderwijs aanleggen; en dit is te meer noodzakelijk, omdat de onoverzienbare massa van voorwerpen in een groot Museum voor den leerling niet leerzaam, maar verwarrend is. Bovendien zouden de in zulke inrichtingen, voor zuiver wetenschappelijkke onderzoekingen bestemde, dikwerf zeer kostbare en niet te vervangen roorwerpen, door het heen en weêr dragen naar en van het auditorium, door het gebruik, het bevoelen of de algemeene onbekendheid met de wijze van behandeling, voortdurend schade lijden, of wel gedeeltelijk, wat in dit geval gelijk staat met geheel, vernield worden. Dit alles beperkt het onderricht van den gewonen leerling in groote musea tot een peripatetisch onderwịs, terwijl hij, in bijzondere gevallen, evenals elk ander geleerde, zelfstandig in de verzameling werken kan.

De bezigheden der ambtenareu bij eene zoo groote instelling behooren bovendien tot een' geheel anderen werkkring. Zij mogen nooit stilstaan, en veroorloven derhalve geene vaste en regelmatige vacanties; zij laten geen' tijd over voor voorlezingen; zij eischen eene voortdurende en grondige studie der vergelij]kende physische geographie en eene menigte practische kundigheden, zelfs die van den handel en van het juiste en spaarzame gebruik der stoffelijke middelen niet uitgesloten. Wijders sluiten zij in zich het strenge toezicht op de naar verhouding talrij]ke, mindere beambten; het onafgebroken streven, de gapingen in de verzameling aan te vullen; deze te bewaren, te rangschikken, te bestemmen; te zorgen, dat de dieren volkomen naar de natuur worden opgezet, en nog veel andere dingen meer; en eindelijk om de resultaten van de onderzoekingen aan de wetenschap in te dienen. Het toezicht op zulke verzamelingen vereischt dus een' homo totus quantus, nitgerust met zeer eigenaardige kundigheden, die slechts door langdurige oefening en ondervinding kunnen worden verkregen, en die hem bovendien, door verdeeling van den arbeid 
met zijn personeel, in staat stellen de wetensehap in al hare bijzonderheden te vertegenwoordigen. Tot groot nadeel der wetensehap zijn er echter velen, die zulke werkzaamhelen noch verstaan noch beoordeelen knnnen en, wat het ergste is, ze, als vermeende bijziak, met geringsehatting voorbijgaan.

Trots deze zeer versehillende omstandigheden, vergunde men den toenmaligen hoogleeraar der philosophisehe facnlteit een soort aandeel in de werkzaamheden van het Musenm. Deze hoogleeraar ${ }^{*}$ ) hield, more majornm, niet alleen voorlezingen over zoölogie en vergelijkende anatomie, maxr ook over anthropologie, mineralogie, geologie, en bij gelegenheid ook over botanie; lasten, die niemand op zijne schonders kan laden, die de grens wil oversehrijden om bekende dingen aan den leek te verkondigen.

Hij was een man, met een voortreffelijk geheugen begiftigd, zeer ervaren in de mensehelijke schedelleer, en bezield met liefde voor grondige nasporingen, zooals trouwens zijne werken bewïzen; maar zijn zeer beperkt gezichtsvermogen, zijue onbeholpenheid en onhandigheid, en het grubrek aan de gave eener zelfstandige opvattiug, stonden hen gedurig in den weg. Hij herkende alleen het enkele, uiet het geheel, en harmonisehe besehonwingen bleven hem vreemd. Vóór zijne beroeping naar Leiden had hij zich, zooals hij zelf bekende, wel is waar met vergelijkende anatomie, maar nauwelijks met zoölogie bezig gehonden, en toen ter tijd kwam hij mij dikwijls om raad vragen Hij heeft zijn' naam hoofuzakelijk aan de uitgave van zijnı $\gg$ Handboek der Dierkunde" te danken, welk werk uit boeken en de zorgvnldig gedetermineerde en gerangschikte verzamelingen van het Museun geput, als eene handige compilatie toen aan velen. zeer welkom was. Ik werd gesteld tegenover zulk een' man $\dagger$ ), die niet het minste begrip ran den aard eener zoodanige

*) Jan van der Hoeven.

†) JaN v. D. HoEven werd cien 14en Juni 1858 tot opperdirecteur benoernd, terwijl men aan Schleger den titel van Directeur gaf, en 


\section{(61)}

inruchting had, en die evenmin den wil bezat ze te leeren kennen*); een man, die de hooge meening, welke hij vau zich zelven koesterde, onder het masker van eene ootmoedige bescheidenheid wist te verbergen.

Intusschen had men onze wederzijdsche verhouding door wettige vonrschriften zoodanig vastgesteld, dat elke willekeurige uitlegrging onmogelijk werd. Maar op indiscreties en aanmatigingen volgden weldra van zijn' kant overtredingen, die mij zelfs eens noopten, toen hij onvoorzichtiglijk hulp van hooger hand had ingeroepen, eene herhaling van de bekende scène tusschen den vrijheer von PLoxнo met den notaris APRIL, zij het dan ook in gematigden vorm, te be-

men die miskenning zijner verdiensten traehtte goed te maken door hem den titel van Hongleeraar te verleenen.

*) Hij ging zoo ver van te willen beweren, dat het voor het Museum voldoende was, als er van elke soort sleehts éen, of, bij geslachtsverschil, twee individuen aanwezig waren: wat zooveel zeggen wil, als de geheele grondgerlachte der instelling, namelijk de kennis der soort, ovcrhoop te werpen, en tot eene verzaneling voor sehoolgebruik te verlagen, en de wetensehap naar lang vergeten tijden terng te brengen. Wijders winschte hij die geheele, zoo ontzettend uitgebreide, verzameling naar het, in zijn Handhoek aangenomen, systeem te doen rangselikken : een aanmatigende en ouverstandige eisch; dien ik des te minder kon veroorloven, daar hij in het geheel niet uitvoerbaar was, en omdat ik meende zijn. boek reeds lang ontgroeid te zijn.

Om eehter mijn' goeden wil te toonen, trad ik in een ander zijner voorslagen tot zoogenaamde betere inriehting van het Museum. Het was namelijk een steen des anstoots voor hem, dat men op de middelste verdieping van het gehouw, links naar de vogels en rechts naar de zoogdieren binnentrad; terwijl in de bovenste verdieping, waar zich de skeletten bevonden, het omgekcerde plaats vond. Want, naar zijne meening, moest, zelfs op verschillende verdiepingen, soort boven soort staan, hetgeen toch cigenlijk eene geheel onversehillige kwestie is. Deze geheel nuttelonze verandering kostte over de 200 gulden; mijne beste ondergesehikten werkten er zes weken aan, en vele voorwerpen leden, niettegenstainde het zorgruldigst toezieht, meer of minder sehade. Deze voorbeelden zijn voldoende om den gezichtskring van den man te kensehetsen. 
werkstelligen. Zijn hem het meest genegen begunstiger LozAC miskende zelfs onze persoonlij]kheid zoodanig, dat zijn later oordeel geheel tegenovergesteld werd.

Voor het overige was deze een veelbelezen, rechtschapen en zeer achtenswaardig man, van eene meer dan tastbare openhartigheid, die zich door warmbloedige drift liet beheerschen en daaroin, als hij zich vergat, tegenover den bedaard geblevene, altijd aan het kortste eindje trok.

Het ging hem niet beter met zijn streven naar populariteit, die hij bijzonder hoogschatte en die hij vele jaren lang genoot, maar in weinig weken verloor, nadat hij het hoogste glanspunt in den staat bereikt had. Niet in staat zich op dit glibberig toppunt te handhaven, moest hij er van afdalen, en begreep toen eerst de waarheid van het spreekwoord: " nil incertius vulgo", dat hij, als een degelijk latinist, toch wel in Cicerro moest gelezen hebben.

Het onnatuurliịk en onviuchtbaar huwelijk tusschen het Museum en de Universiteit was helaas in stilte voltrokken. Men had, ter wille daarvan, de geheele toelromst der stichting op het spel gezet, en de stemmen, die zich zelfs in de tweede kamer, daartegen verhieven, vervlogen in de lucht, omdat zij niets dan eene reeds uitgemaakte zaak konden bestrijden. Maar de inwendige wreker bleef niet uit. Met zulk eene tegenpartij was het onmogelijk zich te verstaan; hij gaf zich keer op keer bloot en groef, zonder dat ik er het minst toe deed, langzamerhand zelf zijn eigen graf; ja, in zijne drift ging hij zoo ver van te verklaren, dat hij ten gevolge der door de wet bepaalde voorschriften, an het Museum niets anders was dan mijn brievenbesteller en het vijfde rad aan den wagen: voor het overige eene zeer juiste en treffende opmerking. Eindelijk, nadat hij zich bij iedereen, zelfs bij zijue beschermers, onmogelijk had gemaakt, nam hij nit eigen beweging zijn ontslag (16 Juni 1860). Hij toonde zich bij deze gelegenheid in een ander licht, en bevestigde het onde gezegde, dat zelfs de in den dagelijkschen omgang meest beminnenswaardige lieden, in zaken 
dikwijls een tegenovergesteld of beter gezegd onwaar karakter toomen, en ronduit gezegd ongeschikt voor den omgang worden.

Hoe Scmleger thans, uu hij de handen vrij had, het $\mathrm{Mu}$ seum inrichtte en binnen weinige jaren tot een' ongekenden bloei opvoerde, zoodat het weldra de evenkuie werd van de grootste Musea in Europa, zoo zij die niet al overtrof, dit alles is nitvoerig door deu Heer Sneldeman in 》Mannen van Beteekenis" uiteengezet. Tot den bloei van het Museum droeg niet weinig bij de op zijn voorstel gedane reizen van Bernstern, Rostinerg en Hoedr in onzen Indischeu Archipel, terwijl ik hem uit China, van welk land het Museum zoo goed als niets bezat, en waar ik mij destijds *) bevond, eene door mij gemaakte rijke verzameling van Chineesche dieren, hoofdzakelijk vogels, visschen, insecten en mineraleu toezond; eene verzameling des te rijker en uuttiger, daar ik mij, op verzoek van mijn' vader, er' op toegelegd had, zooveel mogelijk vau elke soort volledige seriën te verzamelen $\dagger$ );

*) Van $1858-1862$.

†) Mijn vriend, de bokende, thans overleden Zoöloog, Roв. SwInнoe, die zieh destijls met mij in China bevond, en eveneens verzamelde, zond de duplienten zijner vogelverzameling, die nict zoo rijk was als de mijne, daar ik daaronder loogst zeldzame exemplaren bezat, a) naar Londen, waar hij ze an een' haudelaar in naturaliën voor duizend pond sterling (zegge twallfduizend gu!den) verkocht.

Voor de door unij ann de regeering gesehonken rijke verzameling ontring ik nooit den minsten dank; en vond $i k$, toen ik tien jaar

a) Ik noem slechts den Lobivanellus inornatus, waarvan toen in geheel Europa alleen het Leidsch Mnseum éen enkel exemplaar uit Japan bezat, en waarvan ik te Emoi het tweede sehoot; de Muscicapa $M u$ ginaki; de door mij ontrdekte en naar mij genocmde Anthus Gusiavi; twee nieure speeies van Pennatuliden (Pteroides Chinense en Holosceptrum Gustavianum) door HerkLots besehreven, en eene menigte nieuwe vissehen, waarvan BLEEKEn er vier beschreef: de Pteroplatea Schlegeli, de Pseudosciaéna amblyceps, de Pseudosciaena amoyensis en de Arius Schlegeli. 
want volgens hem was dit de eenige ware methode van verzamelen en sehreef hij daaromtrent nog kort voor zijn' dood in de voorrede van de Mededeelingen over Liberia door J. Büttikofer en C. F. SALA: „Reeds in vroegere jaren was ik tot de overtuiging gekomeu, dat de ware wetensehap der Zoölogie alleen op de grondige cn volledige bekendheid met de grondvormen berust, welke wij species en eonspeeies noemen, met inbegrip der constante en individueele variëteiten, en verder, dat de Zoölogie eerst dan haren naam als wetensehap verdieut en tot haar volle reeht komt, wanneer zij uit het hoogere oogpunt der physisehe geographie wordt besehouwd. Uit deze beginselen blijkt duidclijk, dat een dieper inzicht in de dierkunde sleehts in een van die eentrale musea kan worden verkregen, welke de meest mogclijke soorten bevatten, cn waarin ieder dier soorten door complete seric̈n van goed onderhouden individuen is vertegenwoordigd, en wel zoo, dat haar geheel alle verschijuselen van iedere soort naar leeftijd, geslaeht, jaargetijde, variëteit, woonplaats, te zien geeft".

Het gevolg van deze diep gewortelde overtuiging was de geheel systematische, streng wetensehappelijke, rangsehikking der voorwerpen in het Museum, die, zooals hij in eene nota op het Rapport der Commissie voor een nieuw museumgebouw iu 1878 schreef, »eene in zich afgesloten rịj van elke »afzonderlijke groep moest exponeercu, welke gezamenlijk als sevenveel hoofdstukken van eell boek te besehouwen zijı,

later in Leiden terugkwam, het grootste gedeelte mijner huiden nog onopgezet in de magazijnen liggen. Zulke handelwijze van de zijjle der Regeering en der nationale instellingen is niet gesehikt om den ijver van ambtenaren of partieulieren in onze koloniën aan te moedigen; en magr het dan ook wel geen wonder baren, dat deze hunne colleeties lievr aan vreemde instellingen of Musea zenden, die zulke, met veel moeite en kosten bijeengregnarde schatten een' beteren dank waardig keuren, dan, zooals ten onzent gesehiedt, eene droge vermelding in cle "Staatseourant” of de nog treuriger tookenning van de medaille voor verdienste $a$ ). G. S.

a) Men leze wat de "Berliner Münzblätter” (No. 42, Februni 1884) omtrent de achting, die deze medaille geniet, schrijven.

G. s. 
- waarvan de bladen, door de kasten vertegenwoordigd, alle >tegelijk opengeslagen, en als het ware te lezen zijn".

Dat die methode thans door velen bestreden wordt, op grond, dat zij roor den niet vakman erg eentonig en vervelend is, is bekend. Dat de leek er aldus over oordeelt, is niet te verwonderen en hem zelfs niet kwalijk te nemen. Maar dit oordeel wordt ook gedeeld door sommige geleerden van het vak, die liever een Museum zouden willen inrichten, dat bijj het groote publiek meer belangstelling in de zoölogie zou inboezemen en waarheen zelfs het profanum vulgus als eene plaats van uitspanning kon heentrekken. Zulk een wensch zal echter altijd eene utopie moeten blijven. Musea zijn geene galanteriewiukels of kermistenten; zij zijn voor de geleerden eene natuurlijke bibliotheek, »Het boek der Natuur" binnen eene beperkte ruimte besloten; en, evenals eene bibliotheek ook slechts roor den geleerde, die er gebruik van weuscht te maken, bestemd is, en niet een rarekiek roor het gewone publiek*), zoo is dit o. i. ook het geval met een Museum, en vooral een Museum van Nat. Historie. Zulk een Museum anders in te richten dan volgens de streng wetenschappelijke, systematische methode, staat gelijk met eene bibliotheek, niet volgens de vakken van wetenschap, kunst en nijverheid te rangschikken, maar volgens de min of meer kleurige bandjes of het formaat. Voor het onderwijs of roor bet publiek dient men dan eene bijzontere verzameling aan te leggen, op de wijze zooals de Engelschen dit doen en die men zeer terecht aldaar "Representative Collection" noemt.

*) Zoo mag b. v, in dle bibliotheck der L.eidsche Hoogeschool geen geleerde zclf naar een boek gaan zoeken. Hij moet het verlangde werk opgeven, en dan haalt de custos het. Daar er echter geen gedrukte eatalogus nitgegeven is, zoo wext men niet wat er aanwezig is; on ik weet nit ondervinding dat men, zelf in wne boekerij snuffelendc, dikwijls boeken vindt, warvan men het bestann niet vermochlde. Toch heeft er zich nog nooit eene stem tegen vcrheven, dat de bibliotheken niet voor het publiek tnegankelijk ziju. Waarom dan wel ten opziehte van de Musea van Nat. Hist.? 
De nieuw benoemde directeur van het Museum van Nat. Historie heeft eene proef genomen met het Museum des zondags voor het groote publick open ite stellen. Niet dat het aan deelneming ontbroken hecft; integendeel, duizenden hebben vall die openstelling gebruik gemaakt, maar het bezoek van zulke talrijke gasten brengt, vooral op regendagen, als het bezock het drukst is, veel vnil mede, dat des maandags morgens moet worden opgeveegd, en wij rreezcn, dat de daardoor veroorzaakte stof minder gunstig is voor de tentoongestelde voorwerpen, hoofdzakelijk voor die, welke niet in glazen kasten zijn besloten.

"De verzamelingen in het Museum", vervolgt mijn vader, »hadden langzamerhand zulk eene uitbreiding gekregen, dat zij], als in een magazijn, achter en boven elkander moesten opgestapeld worden. Het reeds lang gekoesterde denkbeeld, om aan deze instelling eene passende platatsruimte te doen geworden, kwam eindelijk tot rïjpheid.

Het kamerlid jonkheer J. VElHEYEx, een vurig vereerder der dierkunde, en in dit vak vroeger een lecrling van het Museum, nam de taak op zich, de regecring aan te sporen, nieuwe gebouwen voor een Museum en eene Hoogeschool te laten oprichten. Zijne met vakkennis en warmte gehouden rede werkte zoo overtuigend, dat ziju voorstel in beide kamers eenstemmig werd aangenomen: een zeldzaam geval, maar dat de groote liefde tot de wetenschappen, de trots des Nederlandschen volks, bewijst.

Plannen voor een nieuw Museumgebouw had ik reeds sinds vele jarcn gemaakt, Inaar van het plan tot de uitroevoering is eene groote schrede, ondat veelstemmige adviezen het eindbesluit verlammen en ophouden. Bouwneesters zijn bovendien gewoon niet elke opdracht zoodanig op te vatten, dat zij voor anderen bouwen: zij bouwen voor zich zelven, oindat zij ieder hunner werken als een aanbevelingskaartje beschouwen. Een gebouw echter hecft slechts dan waarde, wanneer het in allc onderdeelen en als een harmonisch geheel, volkomen aan ziju-doel beantwoordt. 
Wie zou b. v. den Keulschen Dom, dit wonderbaarlijk en geweldig meesterstuk, ten geschenke willen hebben, als de voorwaarde daaraan verbonden werd, dat men hem bewonen moest?

In stede van zich achter de geschiedenis onzichtbaar te maken, treedt men liever op den voorgrond, en dientengevolge ontstaat het armzalig afmatten van den geest om iets nienws uit te vinden, terwijl reeds sinds eenwen alle kunstvormen uitgeput zijn. Deze naar hersenschimmen hakende zncht kan echter tot niets anders leiden, dan tot eene het aesthetisch gevoel kwetsende vermenging van bouwstijlen. De leek is wel is warar gemakkelijk te verblinden. Maar hij, die de hoogere wijding der kunst en wetenschap heeft ontvangen, zal zich niet zoover laten begoochelen, dat hij de grondgedachte van een plan voor zijne, gewoonlijk fraaie en zuivere, of zelfs schilderachtige uitroering over het hoofd ziet.

Ik beleefde eene merkwaardige periode gednrende de studiejaren, die zijne Kon. Hoogheid Prins Willem van Oranje te Leiden doorbracht. De gewone visites werden weldra tot vaste, wekelijksche soirées in het, aan de tijdsomstandigheden beantwoordende, fijnere karakter van het Tabakscollegium van Fr. Wruher, M den Eerste. Onderwerp der gesprekken was eene openhartige bespreking van alle gewichtige $\nabla$ ragen. Daaraan namen deel de Gouverneur van den Prins, de latere Minister van Oorlog, Jonkheer VAX CASEMBnoot, een voortreffelijk, zeer beschaafd man, van een' vasten wil en frissche doortastendheid, wijders de privaat-leeraar en de adjulant van den prins. Ieder, die dezen bescheiden en beminnelijken prins kende en getnige was van zijne vriendelijkheid en goedhartigheid, moest met de schoonste verwachtingen voor zijne toekomst vervuld worden. Voor mij waren deze avonden zeer belangrijk, omdat het onderhoud op vrije, ongedwongene wịjze over vele, buiten het dagelïksch leven lig- 
gende kringen liep, en zij tegelijkertijd eene ongezochte, aangename verpoozing aanboden.

Onder het ministerie THoRBEcke hadden vele veranderingen plaats. Het was zaak allerlei oude misbruiken in den staat af te schaffen, maar hij zag overal misbruiken en verkortte dikwijls den levensdraad van wetenschappelijkc ontwikkeling. De opheffing der Natuurkundige Commissie in Nel. Indië, die in het jaar 1850 plaats greep, was voor bet Museum een harde slag. Men beloofde wel is waar, als men geschikte lieden voor dit doel vond, deze naar Indië te sturen, maar toen ik bij hem aanklopte, zeide hij mij, dat hij van meening was, dat men diergelijke nasporingen aan de particuliere industrie moest overlaten. Op zulk een wonderlijk antwoord meende ils te mocten opmerken, dat de particuliere industrie slechts winstgercnde zaken exploiteerde, en dat, naar dit beginsel, een groot gedeelte der wetenschap en, als gevolg daarvan, ook van het hooger onderwijs, aan de particuliere industrie vervallen moest. Ik voegde er bij, dat het mijn plicht was hem opmerkzaam te maken op wat in mijne wetenschap plaats had, en hem de middelen aan de hand te doen om gelijken tred met de beschaafde, naburige volkeren te kunnen houden; dat ik hem het daartoe noodige ter overweging aanbood, en dat ik mịj bij voorbaat, zooals het een' ambtenaar betaamt, aan zijn besluit onderwierp, en dit »Sine ira et studio" deed; maar dat, in geval van weigering, ous wcderzịdsch standpunt zou veranderen, en ik dan de verantwoordelijkheid ten opzichte der wetenschap van mijne schouders op de zijne zoude schuiven. Daarop nam ik afscheid. Ik moet bekennen, dat de man mijne uiterste beleefdheid met gelijke munt vergold; ja, hij begeleidde mij tot aan de deur, drukte mijne rechterhand tusschen zijne twee handen, en zeide, dat ik maar bij hem moest komen en dat ik ten allen tïjde welkom zoude zijn. 
Werkelïk kende hij later het Museum een prar maal een buitengewoon subsidie toe; wel niet zoo groot als dat wat zijne gunstelingen kregen, maar, naar men zeide, meer dan hij in den regel plaeht te geven. Ook keurde hij, nadat ik mij direct aan den Minister van Koloniën en den Gouverneur-Generaal van Ned. Indië gewend had, de besluiten dezer twee hooge Staatsambtenaren goed, om aan eenige, in Indio aanwezige, natuurkundigen wetensehappelijke reizen toe to vertrouwen. Maar personen, aan het Museum onder mijn toezicht geoefend, werden niet uitgezonden, en werd derhalve het doel niet in die mate bereikt, als het wetenschappelijk standpunt van het Museum eisehte. Тноввеске heeft afwisselend, als minister of als afgevaardigde, den meest beslissenden invloed op de regeeringszaken uitgeoefend, en eerst na zịn' dood stortte zịne heersehappij, evenals die van wijlen Alexander den Groote, inéen.

Hij werd zeer versehillend beoordeeld. Zijne partijgangers plaatsten hem in beroemdheid naast of zelfs boven Sir RoBERT PEEL; voor zijne tegenpartij was hij bijkans berucht. De meesten hebben hem alleen als Staatsman gekend. Voor hij zich aan de vormen, van dien kring onderworpen had, was zijn aard veel ongegeneerder. Toen hij in 1830 als hoogleeraar van Gent naar lieiden beroepen werd, had hij hier sleehts weinige vrienden en aanhangers. De menschen, steeds tot spotternij geneigd, maakten zieh vroolïk over zijne lange, hoekige gestalte; de uitdrukking van zij̄n gelaat had veel van eene earieatuur; hij zelf was ontoegankelijk en stiet de lieden door zijn grof, professoraal, despotisch wezen voor het hoofd, terwijl hij aan zijn bandeloos oordeel vrije uiting gaf. Zoo noemde bij b. v. het Museum van Nat. Hist., »het apenhuis", het Herbarium den »Hooizolder", en op zijn eollege gaf hij onderstaande definitie van de eerste Kamer: „De eerste Kamer is de groote vuiluisbak, waarin men al het voor den Staat nutteloos geworden vuilnis werpt". Zijne beide vrienden stiet hij op eene hoogst beleedigende wijze $\operatorname{van}$ zieh af. Wie hem niet huldigde, bestond in 
zijne oogen niet. Hij verhief zich boven allen, duldde wiemand naast zich, maar onder zich, wie slechts wilde. Ten gevolge daarvan, en door zijjn gebrek aan menschenkennis, haalde hij dikwerf middelmatige lieden, ja zelfs gladde praters, aan en maakte zich degelijke lieden tot vijanden. $\mathrm{H}_{\mathrm{ij}}$ oefende zijn geheele leven lang de kunst uit, anderen te imponeeren, en het gelukte hem daardoor onwetende en zelfs vele knappe liedeu aan zich te onderwerpen; hij verstond de kunst, de uplettendheid op zich te vestigeu, en trad overal als ecn leermeester op. Behalve van de Rechten en misschien ook van de Philosophie, schijnt hij weiuig begrip van de wetenschappen gehad te hebben*). Zijne borst was, om mij van eene oude uitdrukking te bedienen, driewerf met brons gestaald; hij verried door zijn gebarenspel nooit wat in zijn binneuste omging, eu als een zijner aanhangers voor hem gevallen was, merkte deze het dikwijls eerst geruimen tijd later. Hij toonde in alles groote kalmte, was nitermate voorzichtig en buitengewoon langzaam. Zijne bevelen waren zoo nauwheurig, dat het een waar genoegen was ze ten uitvoer te leggen; daarentegen wareu zijjne beloften te onbestemd voor eenige hoop op zekerheid. Tusschen de geleerden en hem hadden dikwerf botsingen plaats, o. a. met het Kon. Ned. Instituut te Amsterdam, die eens zoo hoog liepen, dat de leden van dit lichaam hun outslag indienden. Ik deed dit niet, omdat de Koning, en niet de Minister de leden benoemt. Men zeide mij, wel is waar, dat het besluit

*) Toen ik eens aan een' feestdisch naast hem zat en het onderhoud uitsluitend tusschen ons beiden gevoerd werd, zette hij 0 . a. breedroerig zijne beschouwingen omtrent de toekomst der natuurwetenschappen uiteen, cn beweerde, dat deze alleen tot rijpheid konden komen, indien zij zich bij de philosophie van SchUвERT uit München aansloten. Ik meende verkeerd verstaan te hebben, en ondervroeg hem nog eens. Hij bedoelde werkelijk SchuberT, den suikerzoten Illuminaat, die trouwens ook Holland en Jeruzalem bezocht had, gronte geleerdheid bezat, en ecn zeor beminnenswaardig man was. Maar ScHUBerT en de wetenschap! men oordeele zelf. 
den Koning was opgedrongen, maar ik antwoordde: »men dwingt een' Koning niet". Dientengevolge werd ik voor een' ingekankerden Thorbeckiaan gehouden.

$\mathrm{H}_{\mathrm{ij}}$ was echter een hoogst rechtschapen en zedelijk man; hij had het Nederlandsche Staatsrecht en de Grondwet bestudeerd, zooals niemand anders, en zịn oordeel daaromtrent getuigde zoowel van diep inzicht als van groote gematigdheid. De studeerende jengd rook instinctmatig den naderenden Nieuwen Tijd vau het jaar 1848. Zij voelde, dat hij de man was, die geroepen was haar hem te gemoet te brengen, en zoo vormde zich om hem, met behulp van eenige zij̣ner vroegere leerlingen, in zekeren zin eene eigene rechtsfaculteit.

De grootc massa in de stad onttrok hem daarentegen hare sympathie, en toen hij afgevaardigde wenschte te worden, was het duidelijk, dat hij het rereischt getal stemmen in de verste verte niet op zich zou kunnen vereenigen. Thans wierp hij zich, achter de coulissen blijvende, door tusschenkomst zijner aanhangers, in de armen der geestelijkheid. Dit hielp! Maar liberalisme en priesterdom, welk een verbond! Het ging onzen Staatsman dan ook, zooals te vermoeden was. Hij werd door de geestelijkheid geëxploiteerd, en daarna door haar losgelaten.

Zoo heb ik dien man gekend, en met mij vele anderen. 'Zijne aanhangers verdedigden hem dikwijls met het oude gezegde: "war veel licht is, is ook veel schaduw". Maar zulk een gezeguie laat ik alleen gelden ten opzichte van een" Kardinaal de Richelieu met zijne verliefde malligheden; van een' Sully, die tot afwisseling danste en op zijn' ouden dag den opgeblazen gek speelde, maar niet ten opzichte van den geleerde, die slechts door het afwerpen van de alledaagsche, menschelijke zwakheden, nut van zijne studie trekken kan.

Ilk moet thans eenige jaren teruggaan om eene der treurigste slagen te vermelden, die mijn' vader troffen. Dit was het verlies van zijne begaafde gade op den $2^{\text {en }}$ December 
van het jaar 1864. De slag was te gevoeliger, daar mịn vader, uit den aard zijner werkzaamheden, geheel en al onbekend was met huishoudelijke zaken, en steeds een slecht financier was geweest. Zoolang zijne vrouw leefde, had hij zich daarom nooit behoeven te bekommeren. Ten allen tijde was zijn huis gereed om vreemdelingen te ontvangen, en wanneer hij, zooals herhaaldelijk gebeurde, tegen tien of elf uur des morgens van uit het Museum een briefje naar DE VLIET stuurde, dat hij om 12 uur een paar vreemdelingen, die bij hem op het Museum gekomen waren, voor de koffie zoude medebrengen, was zij op den bestemden tijd gekleed, en met een déjeuner gereed om die vreemdelingen te ontvangen en de honneurs van het huis waar te nemen. Het spreekt van zelf, dat die onbegrensde gastrrijheid nooit uit het ellendige traktement, dat mijn vader toenmaals genoot, kon bekostigd worden, maar hij had het een' geleerde zoo zeldzaam te beurt vallende geluk, met zijne werken geld te verdienen. Van zijne hand vond ik daromtrent de navolgende aanteekeningen:

Behalve een jaarlijksch bedrag van circa $f 200$ voor anonieme verhandelingen in Duitsche tijdschriften ontving hị : voor de Prijssraag over het trekken van vogels $f$ 300.-

》 » den Koekoek . . . " 150.-

» \$auna Japonica, Honorarium 30 afl. à / 125 » 3750.voor 230 platen à $f 15$. - . . ” 3450 . -

\ Essai s.l. physionomie des serpents. . ” 800.-

» Verhand. onzer Overzee. Bezitt. Honor.

40 bladen à $f$ 25... . . . . 》 1000.-

41 platen à $f 30$. - . . . . . »1230.-

》 Revue critique des oiseaux de l'Europe » 300.-

» Prijsvr. van TLYLER over natuurk, teeken. 》 400.-

» Diergaarde van Amsterdam . . . . » 300.-

» Loxiens, 53 platen à $f 12 .-$. . . „ 636.-

》 Zoogdieren, 23 platen à $f 20$. - . . " 460.-

- Bịjdr. Zonl Gesellschaft, 20 pl. à $f 25-\frac{}{\text { Transporteeren }} \frac{\text { 575.- }}{f \text { 13351.- }}$ 
Honorarium . . . . . . . . . \300.-

voor deVogels van Nerlerland, 360 platen à $f 4$. — $\quad 1440$. -

Tekst . . . . . \ $400 .-$

$»$ de Toerako's . . . . . . . . . \1000.-

\ Handboek der Dierkunde, platen . . . » 1000.-

\ Susemihl . . . . . . . . . . \ 110.-

» Abbildungen Amphibien 1831 1840 . »1942.-

te zamen $\bar{f} 2 \overline{1043 .-}$

De verkoop van Auteurs exemplaren leverde hem op:

Fauna Japonica .

400.

2 Traité de Fauconnerie. . . . . . \$ 150.-

3 Abbildungen . . . . . . . . . \ 90.-

3 Essais s. 1. phys. des Serpents . . . » 45.-

3 Abhandlungen . . . . . . . . \30.-

3 Revue critique. . . . . . . . \10.-

3 Loxiens . . . . . . ${ }_{\text {Totaal }} \frac{75 .-}{f 21843 .-}$

Zoodat hij gemiddeld $f 1000$ 's jaars bij zijn traktement verdiende. Desniettegenstaande had hij voortdurend met financiëele moeilijkheden te kampen, daar het leven gaandeweg duurder werd, zijne kinderen grooter werden, terwijl zijne positie niet verbeterde.

In 1869 hertrouwde hij met de behuwddochter van zijn' vriend Prof. vaN Lith de Jeude uit Utrecht, Mej. A. C. P. Premper, die hij reeds vroeger had leeren kennen (hij had zelfs in 1866 een' vogel naar haar Charitornis Albertinae genoemd); en door well huwelijk hem een onbezorgde ouderdom werd gewaarborgd. Vrij van huiselijke beslommeringen, vatte hij een nieuw plan op om de nog zoo weinig bekende Westkust van Afrika te laten onderzoeken. Daarvoor boden zich twee personen aan. Zijn assistent de Heer Bürrixorer, thans Conservator aan het Museum van Nat. Hist. en de Heer SALA, een ervaren jager, die rroeger reeds een aantal jaren in tropische gewesten had doorgebracht. De onder- 
neming had niet den gunstigen uitslag, dien SCHLEGEL er zich van had voorgesteld, hoofdzakelijk door de moeilijkheden, waarmede men op een onbekend terrein te worstelen heeft, als ook door den dood van den Heer SALA en de ziekte van deu Heer BüTTIKOFER, die eenen ommiddellïjken terugkeer naar het vaderland vereischte. Zij kan echter, onder gunstige omstandigheden, goede resultaten opleveren, en de Heer Bütrikofer heeft dan ook niet geaarzeld op eigen risico een' anderen reiziger, den Heer STAMPFLIE, naar Liberia te zenden.

Ik keer tot de laatste bladzijde der autobiographie mijus vaders terug, en wel tot den tijd toen E. SELENKa te Leiden kwam. »Ik denk aan dien tijd", zegt ScHtegel, met innig genoegen terug. Voor dien tijjd was hij mij persoonlijk geheel onbekend, maar ik had slechts goeds van hem gelezen en gehoord. De gedachte, zulk eene frissche, jeugdige kracht buiteu den Academischen kring te zien verflensen, en de steeds weder opkomende herinnering aan mijn eigen noodlot, bewogen mij hem als oprolger van J. VAN DER HoEves aan te bevelen. Hij heeft zich hier als mensch, als degelijk, kundig en geliefkoosd leeraar, ware vrienden verworven, en slechts ongaarne zagen wij hem weder ons midden verlaten *). Tot zoover loopt de door mijn' vader geschreven autobiographie; de letters en het geschrift werden op het laatst, ten gevolge $\operatorname{van}$ zijn sterk afnemend gezichtsvermogen al reusachtiger, en de laatste bladen waren in plaats van met inkt of potlood, met teekenkrijt geschreven. Zooals de lezer echter zal bespeurd hebben, heeft hij de hoofdmomenten zijus levens alle opgeteekend en de oinstandigheden, onder welke zijne vele geschriften ontstonden, voor het meerendeel vermeld. Uit een paar aanteekeningen, die ik vond, scheen hij ook van plan te zijn geweest eene schets van zijn eigen

*) Zooals bekend s, nam E. Selexka een beroep als hoogleernar naar Lirlangen aan. Hij werd opgevolgd door den vroegeren Conservator ann 's Rijks Museum van het Nat. Historie, Dr. C. K. Hofrmans. 
karakter er bij te voegen, maar bovengenoemde omstandigheid schijnt hem aan de nitvoering van dit voornemen verhinderd te hebben. Dit is te meer te bejammeren, daar niemand beter in staat was darover een oupartijdig oordeel te vellen dan de man die het $\gg$ Nosce te ipsum" zijn geheele leven in practijk gebracht had. Ik zal trachten zoo onpartijdig mogelijk deze leemte nog aan te vullen. Zooals reeds uit de geschiedenis zijner eerste levensjaren genoegzaam blijkt, was mijn vader iemand van eene onvermoeide werkkracht, die door eene bijna onverstoorbare gezondheid gesteund werd *). Hij was doortastend, steeds werkzaam met den geest, zelfs op plaatsen van uitspanning; had eene fijne opmerkingsgave, die hem in staat stelde, in dingen, die een ander voorbijloopt, de merkwaardigste verschijnselen waar te nemen. Daarbij was hịj echter onbuigzaam van geest, zooals hij reeds in zijne jeugd in den strïjd met zijne leermeesters en zijn' vader getoond had, op vele punten eigenzinnig en moeilijk tot andere gedachten te brengen, hoewel hị voor een klaar betoog niet onvatbaar was, en dan de eerste was om zijne verkeerde meening te erkennen en te verwerpen.

Hij was een vriend van vroeg opstaan, zat meestal al om vijf uur aan zijne schrijftafel en had dan om 8 uur, zooals hij zich uitdrukte, reeds zooveel gewerkt, als een ander in éen geheelen dag afgedaan had. Van daar, dat hị den tijd vond om niet alleen een groot aantal werken te schrijven, maar ook om elken zaterdag op de jacht te gaan $\dagger$ ), de oproeding eu het onderwijs zijner kinderen yeheel op zich

*) Hij had b. v. nooit hoofdpijn gehad, en was slechts éens in zijn leven, tusschen de jaren 1847 en 1848, bedenkelijk ziek: eene aandoening van het.hart, waarvan zijn broeder F. SCHLEGEL hem totaal genas.

†) Voor hem bestond geen gesloten jachttijd; hij had de vergunning om, ten behoeve van het Museum, het geheele jaar door dieren to schieten. Ook de weg langs de spoorwegen was voor hem vrijgesteld. 
te nemen, en de avonden aan het gezellig verkeer of aan de muziek te wijden. Hij werkte nooit des avonds laat; te 10 uren werden de boeken gesloten en te elf uren ging hij naar bed, waarin hij dan nog een half nurtje bleef lezen, meestal romanliteratuur, ten einde den gezonden slaap niet door hoofdbrekende lectuur te verjagen.

De redactie zijner werken had altijd mentaliter plaats. Hij sehreef nooit een klad, maar alleen enkele, losse aanteekeningen, en eerst als hij het geheele werk in zịjn hoofd kant en klaar had, schreef hị het currente calamo neder. Zoo herinner ik mij, dat hij zijn haudboek der Dierkunde - in acht weken geschreven heeft. Teu einde zelf klaarheid in zijue redactie te brengen, had hij.j de gewoonte om zijn werk bij stukken aan een vriend, aan éen zijner kiuderen, ja zelfs aan de praeparateurs en andere beambten van het Museum te vertellen. Dit had den sehijn alsof hij doceeren wilde, maar feitelijk diende deze mondelinge voodraeht tot hetzelfde doel als een schriftelijk klad voor een' anderen geleerde, n.l. on mogelijlke leemten te ontdekken, aan te vullen of te verbeteren.

Voor de in deze zijne gewoonte ingewijden, was het dikwerf kluehtig, het balf onderdrukte gapen op te merken, dat de al te zware en rijkkelịjk toegediende wetensehappelijke kost bij de minder ontrvikkelde tochoorders opwekte, en verweet ik hem wel eens in seherts, dat hij ten behoeve zijner wetenschap vivisectie op den menseh pleegde. Zueht om zieh vooruit te dringen of te poseeren ontbrak hem gehcel. Daarentegen was hij volstrekt niet onverschillig omtrent de goede meening, die de geleerde wereld van hem koesterde, en deed hem de benoeming tot lid eener wetenschappelijke instelling steeds genoegen. Hij wilde daartoe echter nooit de geringste moeite aauwenden, en meende, dat dergelijke bewijzen ongezocht moesten betoond worden. Zijn vrieud, prins BovaPARTE, wilde hem tot lid van het Instituut van Frankrijk lateu benoemen. Maar, volgeus de walgelijke, fransche methode, was het daarvoor noodzakelijk, dat hij zich per- 
soonlijk in Parijs bij de leden van let Instituut kwam aan. berelen. „Venez faire ros visites", schreef Canrno, »et je vous garantis votre nomination". Maar tot zulk een' vernederenden stap was Schleger niet te bewegen. Toen de Koninklijke Academie van Wetenschappen te Brussel hem tot lid. wenschte te benoemen, verlangde zij te voren eenc lijst zijuer werken. $H_{i j}$ wilde die echter niet geven en merkte op, dat hij thans (in 1857) als zoüloog bekend genoeg was om zich niet aan die formaliteit te storen, en in dit geval liever van het angeboden lidmaatschap afzag. Eerst toen de toenmalige conservator Dr. JeNTINk hem aanbood die lijst*) voor hem samen te stellen, stemde hij er in toe, op voorwaarde, dat die bniten zijne bemoeienis naar Brussel zoude gestuurd worden.

Men kan het, zeide hịj wel eens, den koningen en vorsten niet $k$ walijk nemen, dat zij de verdienstelijke mannen van hun eigen land niet kennen en waardeeren, maar eene wetenschappelijke instelling heeft het excuus van onbekendheid niet, en moest niet op eenc aambeveling, ecn' skruiwagen", wachten om dergelijke mannen een openbaar bewijs van waardeering te geven.

Van daar dan ook, dat hij aan vorstelijke bewijzen in den vorm van ridderorden geene waarde hechtte. Hij wist zeer goed, dat de meeste vorsten te weinig in de gelegenheid zijn om persoonlijk over wctenschappelijke verdiensten te kunnen oordeelen $\dagger$ ), en dat dus een toegekend lintije

*) Men vindt deze zeer complecte lijst, dic de Heer Jentink zoo vriendelijk was mij af te staan, onder de Bijlagen.

†) Eene gunstige uitzondering hierop hebben ten allen tijule de Thüringische vorsten gemaakt, die zelf wetenschap en kunst beoefenden. Mar men leze b. v. eens de oorkoude warbij Koning Frenerik, WrLLem I van Pruisen de stichting der Berlijnsehe Academie van Wetenschappen octrooicerde, om zieh een begrip te vormen van het lage peil yan wetenschappelijke kennis van dien vorst en zijne raadsmannen. Het was hem hoofdzakelijk daarom te doen, dat de geleerden hem van Kometen en dergelijke schrikinboezemende, hemelsche ver- 
geen bewijs van hunne eigene waardeering is, maar alleen het gevolg van de aanbeveling van den eenen of anderen invloedrijken persoon. Het was dan ook waarschijnlijk op deze wijze, dat hem bij het $3^{e}$ eeuwfeest der Leidsche Academie, het ridderkruis van den Nederlandschen leeuw werd thuis gezonden. In dit geval eerder eene bespotting ${ }^{*}$ ) dan een blijk van waardeering. Hij hechtte er dan ook niet de minste waarde aan; en toen kort daarop Milse Edwards van den Jardin des plantes Leiden bezocht en van den merkwaardigen, dikbehaarden aap sprak, dien de zendeling $\mathrm{D}_{\mathrm{Av} \text { ID }}$ in het met sneeuw bedekte hooggebergte van westelijk China ontdekt had, en waarvan SoHLEGEL gaarne een exemplaar voor het Leidsch Museum had gehad; toen hij, vernemende, dat mijn vader tot ridder benoemd was, hem daarmede gelukwenschte, antwoordde deze: »Comment! vous y attachez une pareille importance? Moi j'aimerais nieux avoir votre singe que mon lion". Getroffen door deze woordspeling, antwoordde Milne Edwards, met de den Franschen eigenaardige gevatheid en hoffelijkheid, onmiddellijk : Vous l'aurez," en zond ook later het eenige, tweede exemplaar van den Rhinopithecus Roxellanae naar Leiden, waar hij thans in het Museum prijkt.

Ik moet thans een oogenblik stilstaan bij den strijd, dien

schijnselen het noodige voorspellen konden. En het is nog heden met de meeste Europeesche vorsten niet beter gesteld, en zal wel niet beter worden, zoolang in Luropa het boginsel geldt, dat de vorst de eerstc soldaat van zijn rijk moet zijn, en niet, als in China, de ecrste geleurde.

*) Ridderkruizen, lidmaatschappen van gelecrde genootschappen, doctorsbullen honoris causa van Universiteiten, hebben alleen waarde voor jonge geleerden, die, hoewel degelijk en kundig, den tijd nngू ni't hebben gehad om wereldberoemd te worden, ofschoon zij reeds in bunne eigene omgeving en onder hunne vakgenooten bekend of lxroemd zijn. Zij dienen dan om het doornig pad der wetenschap en het nog doorniger pad eener broodwinning effener en gemakkelijker te maken. Aan een beroemd en gevestigd gelcerde zulk eene "Auszeichnung" te verleenen is "Uilen naar Athene dragen". 
SchlEger zijn geheele leven tegen de zoogenaamde leer van $\mathrm{D}_{\triangle \mathrm{R} W I N}$ gevoerd heeft, en in welken strijd hij tot het laatste oogenblik, met het zwaard in de hand, is gevallen, net de woorden »òf ik heb nicts geleerd, ò $\mathrm{D}_{\triangle \mathrm{BR}} \mathrm{iN}$ heeft nooit iets begrepen".

Mijn vader was een groot vereerder van DAkWIN, zoodat hij niet alleen aan mijj, bij mijn vertrek naar China in 1857, maar veel later nog aan BürтIкоFen, toen deze naar Liberia vertrok, als ook aan PolLEEN op zijue reis naar Madagasear, $D_{A R T I N ' s}$ reizen als model mede gaf, waarnaar wij ons bij het waarnemen der natuur moesten gedragen. Geen wonder dus, dat toen Daritrix met zijne theorie omtrent het ontstaan van soorten voor den dag kwam, ik weldra een vurig aanhanger dezer leer werd, daar zij mij toescheen het scheppingsproces veel te vereenvoudigen en verschillende, onbegrijpelijke factoren op te helderen.

Behoef ik te zeggen, dat ik, in 1872 uit Indië teruggekeerd, weldra met mijn' vader in strijd over deze kwestie geraakte, om ten laatste voor zijne overtuigende betogen te zwichten eu weder eene illusie minder rijk te worden. $\Lambda$ priori had hij geene bezwareu tegen de leer, en hij zeide mij herhaaldelijk, dat hij er zich bij zoude nederleggen wanneer men hem slechts een enkel geconstateerd bewijs van overgaug in de natunr, waaruit zich weder eene constante species had ontwikkeld, kon voorleggen. Dat door toedoen van den mensch, zooals b. v. het geval is met de veefokkers eu duivenkweekers, de eerste en eigenlijke leermeesters van DARw1N, zulke species kunnen voortgebracht worden, viel niet te loochenen, maar hij ontkende ten sterkste, dat dit ooit in de rrije natuur, buiten inmenging van den mensch, plaats greep. Het groote verschil tussehen hem en de school van Dartis bestond in de opvatting der natuurverschijnselen. Haddeu b. v. de moerasvogels, volgens de leer van DARININ, lauge pooten gekregen door langzame ontwikkeling uit kortere pooten, naar mate de bodem moerassiger werd, zoo hadden, volgens mijn' vader, die rogels van den beginne 
af aan zulke lange pooten bezeten, omdat zij in de moerassige plassen leven moesten. Maar de grootste reden van zijn antagonisme bestond in het gevaar, dat hij daarin, voornamelijk voor jonge lieden, zag, om zich uit de moeilijkheden eener bevredigende oplossing van het een of ander verschijnsel te redden door de gemakkelijke phrase $>$ 't is een overgang", en omdat zich dikwerf nog geheel onrïpe jonge geleerden, in hunne verbeelding, dat door de $\mathrm{D}_{\mathrm{AnwIN}-}$ sche leer alles thans klaar en duidelijk was, verstoutten tegen den grïzen natuuronderzoeker, wiens geheele leven eene aaneenschakeling van waarneming der natuur was geweest, met de eene of andere machtspreuk op te treden.

Ik herinner mịj nog zeer goed hoe hij een dergelijk jong mensch, die eene zijner bedenkingen met een » Ja, ziet U, Professor! ik ben Darwiniaan" beantwoorlde, met naar boven ge. schoven bril en verontwaardigde, komische woede toeriep: „Wat ben je? Darwiniaan ben je? Niks ben je!" De slordigheid, waarmede de verdedigers van de leer van DARwIN te werk gaan, kwam hem eveneens hoogst gevaarlijk voor. Zoo liet hï mï eene uitgaaf van $D_{\Lambda}$ RWIN zien, waarin tot opheldedering der ontwikkelings-theorie van bet tamme zwijn uit het everzwijn, twee houtsneedjes gevoegd waren, waarvan het eene, dat het everzwïn moest voorstellen, de gravure van den Sus javanicus was. Nog erger maakte het J. C. PriciARD in zijne natuurlijke geschiedenis van den mensch. ${ }^{*}$ )

Bij de beschrijving van het Japansche ras geeft deze eene gravure van een' Japanner tot verduidelijking zijner typische beschrijving. En wat was dit voor een Japanner? 't was het portret van den Chinees Ko-TrING-DZIANG, een inboorling. der provincie Canton nit Zuid-China, dien vos Siebold naar Leiden gebracht had, en wiens portret hij in zijn NipponArchief liad opgenomen. Prichard heeft dus met roekeloone

*) Prichard, Natural History of Man, 4th Ed, Vol. I, p. 234. "The figure from siebold given below represents the most general form of the Japanese plysionomy." 
lichtzinnigheid, zonder den tekst te lezen, uit het NipponArchief het eerste het beste portret geeopieerd, en geeft dit in zijn leerboek als type van een' Japanner, terwijl het de type van een' Zuid-Chinees is. En dat dit geene onwillekeurige vergissing was, blijkt daaruit, dat de zelfde Chinees als koper-rignet buiten op den linnen baud der Engelsehe uitgaaf in gouddruk gestempeld staat. Die paar roorbeelden, waarvan ScHLEgEL echter honderden staaltjes bijeenverzameld had, kunnen dienen om den afkeer te doen begrijpen, dien een zoo nauwgezet en nawłseurig waarnemer als mijn vader Was, tegen de vertegenwoordigers en leeraars der nieuwe theorie moest koesteren. Ik geef ze tevens als waarschuwing voor jonge geleerden, ten einde hun in te prenten, niets op gezag van anderen aan te nemen, maar alles eerst zelf nauwkeurig te toetsen en te controleeren.

Want indien manuen als DARWIN en PrTchard zulke onvergeeflijke vergissingen begaan, wat staat kan men dan makeu op de beweringeu van sterren der tweede of derde grootte?

Schlegr was door de natuur met een stalen geheugen begiftigd. Wat hij eenmaal geleerd had, vergat hij nooit; en nog lkort vóór zijn' dood vertelde «ij CoBET, dat hij op eene wandeling met hem rerbaasd had gestaan, hoe goed hij nog in de klassieke literatuur t'huis was. Zijne voordraeht was altijd duidelijk, piquant en boeiend, onverschillig welk onderw'erp hij behandelde, en al versehilde men ook met hem in meening.

Hij hield niet alleen de vorderingen in zijne eigene wetensehap bij, maar ook die in de andere wetenschappen, en teekeude b. $\nabla$. omtrent de vergelijkende taalstudie aan: $>$ Als angenehme Nebenbesehäftiging galt auch das vergleiehende Sprachstndium, welchem ohnehin jetzt kein Gebildeter mehr ganz fremd sein darf. Schon in der Jugend wurde die Aufmerksamkeit auf dieses Fach gelenkt durch Adelung's Werke, die siel damals iu vielcr Häude befauden; feruer durch 
dessen Nachfolger, den gelehrten Vater, der als ein geborener Altenburger ebenfalls viele Bewunderer in unserer gemeinschaftlichen Geburtsstadt hatte, obschon seine professorale Vornehmheit ihm in dem Wege stand, jene an sich zu ziehen. Der Zufall endlich, dass die Gebrüder Schleger, um dieses Fach so verdient, wenigstens Namensgenossen waren, erweckte meine Neugierde um der Entwickelung dieser Wissenschaft zu folgen, und die Liebe dazu erhielt noch nachhaltiger Nahrung als ein Manu wie Kern, der nicht nur der Sache Meister ist, sondern sie auch gern mittheilt und mitzutheilen versteht, in unserer Mitte gezogen warde, und als einer meiner Söhne, der Sinolog G. SciLEGeL, sich diesem Fache ausschliesslich gewidmet hatte".

Hij sprak en schreef dan ook de nieuwe talen met het meeste gemak en had, ten minste in zijne jeugd, de Saksische onwilligheid der tong om rreemde klanken uit te spreken, rolkomen overwonnen. Toen hij eens in Altenburg, tegelijk met zijn' veel jongeren broeder Frans, eeu bezoek bracht bij zijn' ouden leermeester in het Fransch, zeide deze : $\mathrm{Ja}$, sähn se, lieber Hermann, Sie sind der Einzige, där das Franzeesische gut hat sprechen gelernnt. Da ist sie aber ihr Bruder, der hat sie das niemals erlernen können"; en zich tot laatstgenoemde wendende, zeide hij: »Sag einmal $J e^{\text {"; }}$; fluks antwoordde deze Sche, en had in het volgende oogenblik eene duchtige oorvijg van den verbolgen schoolmeester genoten.

Eerst in later leeftijd kwam "le naturel au galop" terug, en begon hij de Nederlandsche taal, die hij rroeger zeer zuiver gesproken had, weder met een Duitsch-Saksisch accent uit te spreken, en met Germanismen te doorspekken. Ik hoorde hem daareutegen, nog weinige maanden voor zijn' dood, met een' Engelsehmau zoo vloeiend Engelsch spreken, dat deze er over verstomd stond.

Het eenige waaraan men zijn' landaard herkennen kon, was de verwisseling van $\mathrm{P}$ en $\mathrm{B}$, die trouwens in geheel Duitschland, maar vooral in Saksen, zeer gewoon is; en 
maakten wij ons reeds als kinderen vroolijk over de "Zwemblaas" waarmede hij de toen bij de Heerepoort gelegen Zwemplaats aanduidde.

Omtrent zijne inwendige gemoedsaandoeningen was hij zeer gesloten; hij liet zich daarover zelden uit, al gevoelde hij ze ook diep. Toen men hem met het verlies zijner vrouw kwam condoleeren, bracht hij dadelijk het gesprek op andere onderwerpen, en wilde ook later nooit daaraan herinnerd worden. Heıne zegt ergens*): »alle kräftige Menschen lieben das Leben", en zoo hall ook ScHLEgEt bij al zijne wijsbegeerte, eene, ik had haast geschreven, kinderachtige vrees voor den dood. Hij zelf zegt. dit in zijne autobiographie bij gelegenheid van het grafschrift, dat hij voor BoNAPARTE gemaakt had, en dat hij hem niet toezond: $>$ daar toch levenden niet gaarue aan den dood herinuerd worden $i$ )".

Hij nam het mij zeer kwalijk toen ik hem bij mijne terugkomst uit Indië vertelde, dat een ouderlievend zoon in China geen beter bewijjs zijner liefde jegens zijn' vader kon geven, dan hem nog bij zijn !even eene rijkversierde doodkist te vereeren, die de vader aan vrienden en bekenden als een blijk van de deugd zijns zoons vertoonen kon.

Tot het laatst van zijn leven sprak hij dan ook voortdurend van het nieuwe Museumgebouw, en hoe dit dan, als het gereed was, door hem zou ingericht worden; en toen ik hem herhaaldelijk, met het oog op ziju' hoogen leeftijd, aanmaaude om zijn laatste werk te schrijven, scheepte hij mij steeds met een korzelig "Das hat noch Zeit" af. Toen hij er eindelijk mede begon, bracht hij het niet verder dan de tot inleiding dienende autobiographie. Het materiaal, dat hij voor dit werk verzameld had, bestaat uit meer dan zes dikke portefeuilles met losse aanteekeningen; maar zelfs een Schema ran het werk ontbreekt; zuodat dit kostbaar materiaal nutte-

*) Reisebilder, Das Buch le Grand, kapittel III.

†) Zie boven blad, 49. 
oos daar ligt, wijl hij slechts wist, waarvoor en in welken zin het gebruikt en verwerkt moest worden.

Dit krachtig en gezond gestel begon echter toen reeds langzaam te bezwijken. De wandelingen, die hij dagelijks met mij deed, en waarvoor ik hem opzettelijk van het Museum kwam halen, werden steeds meer en neer door hem bekort, ei eindelijk geheel gestaakt en beperkt tot den gang naar en van het Museum. De dringendste vertoogen, niet aan die op zijn' leeftijd zoo gevaarlijke liehaamsvadzigheid toe te geven, bleven vruehteloos. Fen diepe anthrax, die zich bij hem vertoonde, bracht Prof. Rosenstern op het vermoeden van suikerziekte, die ook weldra, zoo al niet in hevige mate, toch aanwezig bleek te zijn. Tot eene ingrijpende kuur in het dieet was hij niet te bewegen en ging hij voort, zij het dan ook iets gematigder, suiker en suikerhoudende voedingsmiddelen te gebruiken.

"Zonder suiker kan de mensch niet bestaan" beweerde hij, en of ik hem al op het voorbeeld der Poolvolkeren wees, die uitsluitend van visch of pleeseh leven eu nooit suiker of suikerloudend voedsel gebruiken; of ik hem al door eigen voorbeeld bewees, dat dit zeer goed kon, en als betoog daarvoor zes weken lang niets dan vleesch en eieren at en sehoon water dronk, het was alles te vergeefs.

»De Eskimo's waren geheel anders georganiseerd dan wij, en een man in de kraeht zijns levens kon dingen doen, die een grịjsaard niet verdragen kon," was al het antwoord, dat hij daarop gaf. Ook het argument, dat hij geene voeding van de suiker had, daar deze toeh niet in zijn organisme werd opgenomen en verbruikt, was niet bestand tegen zijn trek naar zoetigheden.

Zijne oogen, reeds verzrrakt door den inspannenden arbeid bij het teekenen vau honderden vooriverpen op steen, werden zoowel door zijne ziekte, als door een' bijkomenden katarakt ten laatste geheel onbruikbaar. Twee operatiën, aan die oogen gedaan, gaven geene gunstige resultaten, en ten laatste zag hị alleen nog maar zeer grove voorwerpen en die nog 
onduidelijk. Zijue geestkracht bleef echter onverzwakt, en toen hij vreesde op straat ergens tegen aan te loopen, liet hij zich per rijtuig naar het Museum brengen, en zich daar door zijn' amanuensis voorlezen. Eindelịjk scheen hij zelf in November 1883 te gevoelen, dat zijne levenskrachten hem begaven, en bleef hij thuis. Ik bezocht hem toen zoo dikwijls als ik, zonder vermoeden op te wekken alsof ik gevaar in zijn' toestand zag, doen kon. Hij bleef tot kort voor zijn' dood helder van hoofd, sprak over allerlei onderwerpen, maakte nog steeds plannen die, zoodra hij beter was, zouden uitgevoerd worden, en eerst weinige dagen voor ziju overlijden begon hij bij tusschenpoozen te ịlen, maar was dan zelfs nog altijd met dieren bezig. De ontbinding naderde echter nog spoediger dan zijne omgeving dit gedacht had, en eerst den $17^{\text {en }}$ Januari des middags begreep ik dat de levensmachine afgesleten was. Hij overleed dan ook des avonds te half tien, zonder pijn of doodstrijd, en zonder nog één oogenblik sinds dien morgen het bewustzijn herkregen te hebben. Den $21^{\text {en }}$ daaraanvolgende werd hij op het kerkbof bij de Groenesteeg begraven.

Met hem stierf een der laatste vertegenwoordigers van universeele geleerden, waaraan het begin onzer ecuw zoo rijk was, en die thans, door de tot het uiterst gedreven splitsing der wetenschappelijke vakken, niet meer schijuen gevormd te kunnen worden.

Voor de eer en den roem van ons vaderland, vocr de zelfstandigheid en den bloei van het Museum van Natuurlijke Historie, en voor de nagedachtenis aan hem, die deze instelling maakte tot hetgeen zij thans is, de evenknie, zoo niet meer, der grootste Musea in Europa, hopen wij, dat zijn opvolger, Dr. JENTINK, met krachtige hand de beginselen, warop dat Museum gevestigd is, zal weten te handhaven en het zal verdedigen tegen elke poging tot eene samensmelting met de Academie, waardoor de krachtige bloei van het Museum slechts kan belemmerd, zoo niet geheel geknakt worden.

Leiden, September 1884.

G. Schleght. 


\section{LIJST DER GESCHRIFTEN \\ VAN}

HERMAN S S HLEGEL.

1. Verhandeling over een in het jaar 1826 aan de NoordHollandsche kust gestranden Vin-visch (1e kl. N. Verh. III v. h. Kon. Ned. Inst. 1826). Met 2 pl.

2. Erpetologische Notizen (Isis, 1827.)

3. Onderzoekingen van de speekselklieren der slangen met gegroefde tanden, in vergelijking met die der giftige en niet-giftige. Met 1 pl. (Bijdr. t. d. Natuurk. Wet. 1827).

4. Verhandeling ter beantwoording der vrage: Daar er nog veel duisterheid en verschil van gevoelen plaats heeft omtrent de gewesten waarheen zich de bij ons bekend geworden trekvogels begeven, verlangt de Maatschappij bijeengebracht te zien, al hetgeen daaromtrent door ondervinding of door verhalen van wel geloofwaardige schrijvers is bekend geworden. (Bekroond door de Holl. Maatsch. der Wet. te Haarlem, den 17 Mei 1828).

5. Untersuchungen der Speicheldrüsen bei den Schlangen mit gefurchten Zähnen in Vergleich mit denen der giftlosen und giftigen (Nov. Act. acad. Leop. XIV 1) Met 1 pl. Bonn 1828.

6. Verhandeling ter beantwoording der vrage: »Geeft de onleedkundige en physiologische kennis van het maaksel van den Kuekoek of de leefwijze van dezen vogel eenige 
gronden aan de hand, om te verklaren, welke de redeni zij, dat deze vogel geen nest maakt, en zijne eieren niet zelf uitbroeit? Zoo neen, welke is dan de oorzaak van dit merkwarrdig verschijnsel?" (Bekroond door de Holl. Maatsch. der Wet. te Haarlem, den 22 Mei 1830). Met 1 pl.

7. (Met C. J. Temminck) Siebold. Fauna Japonica 18331846. Saurii, batrachii, pisces, aves et mammalia.

8. Monographie van het geslacht Zonurus, met 1 pl. (Tijds. จ. Nat. Gesch. en phys. I 1834).

9. Beschreibung von. Zonurus microlepidotus Cuv. ete. (Arehir f. Naturgesch. II 1836).

10. (Met anderen.) Bruchstücke zu einer Fauna der Berberei 1841 ( $3^{\mathrm{e}}$ deel van Mor. Wagner's Reizen in der Regentschaft Algier in den J. $1836-38$.

11. Abbildungen neuer oder unvollständig bekannten Amphibien, nach der Natur oder dem Leben entworfen, herausgegeben und mit einem erläut. Texte begleitet. 50 pl. 11 bl. tekst. Düsseldorf 1837-44.

12. Essai sur la physionomie des Serpents. Met atlas van 21 pl., 3 kaarten en 1 tableau, 2 vol. 1837.

13. Essay on the physionomy of serpents, met $2 \mathrm{pl}$ en 1 kaart 1844.

14. Bemerkungen auf einem Ausflug nach Paris im Jahre 1835 (Altenburg 1837, Exped. des Eremiten (Fr Gleich).

15. Opmerkingen over Parịjs, Leiden 1839.

16. Over de neusgaten bij Sula (Tijds. v. nat. gesch. en phys. VI 1839).

17. (Met ron Gerraziss) J. C. en E. Süsemind. Abbildungen der Vögel Europa's. 1839-45.

18. (Met S. MüLLER). Verhandelingen over de natuurl. gesch. der Nederl. Overzeesche bezittingen door de leden der Natuurk. Commissie i. O.-I. en andere schrijvers 184045. Zoŏlogie: gewervelde dieren. Met gekl. platen (29 Monographieën).

19. Description d'une nouvelle espèce du genre 'Trigono- 
cephalus (T. LansbergiI) Met 1 pl. (Magazin de Zoologie, 1841.

20. Abhandlungen aus dem Gebiete del Koologie und Vergleichende Anatomie; I, Beiträge zur Charakteristik der Cetaceen, met $6 \mathrm{pl}$. II, weitere Beiträge zur Naturgesch. der Cetaceen. III, Beschreibung einiger neuen grossen Edelfalken aus Europa und den nördl. Afrika, met 5 pl. Leiden 1841-43.

21. (Met C. J. Tемminck). Histoire naturelle des oiseaux Aflv. 1-8, 1841-43. Toen gestaalkt.

22. De diergaarde en het museum van het genootschap Natura Artis Magistra te Amsterdam, in afbeeldingen voorgesteld en beschreven. Amsterdam 1842. Westerman.

23. Uittreksel van: „Beskivelse of nogle nye Slangearter, ved. J. Th. RuinhazDT. Kjöbnhavn 1843". Leiden 25 Sept. 1843.

24. Development and propagation of serpents (Annals of nat. hist. XIII. 1844).

25. Fables and prejudices regarding serpents (Edinb. new Pliil. Journ. vol. 36, 1844).

26. Kritische Uebersicht der Europäischen Vögel, en: Revue critique des oiseaux d'Europe. Leiden 1844. (Fransche en Duitsche telsst.)

27. (Met Verster van Wulverhorst). Traité de Fauconnerie, met 17 zwarte en gekl. pl. Imp. folio. Leiden 1844-53.

28. Bijdragen tot de Dierkunde 1848-1854, bevattende de volgende Monographieën :

28. Over cene nieuwe soort van duif van de kust van Guinea. Columba (Peristera) puella, met $1 \mathrm{pl}$.

29. Observations sur le Sous-genre des Pouillots (FrceDULA) et notamment sur le Pouillot lusciniole, $S y l$ via (Ficedula) polyglotta de Vieillot.

30. Description d'une nouvelle espc̀ce du genre Eryx, Eryx Reinhardtii, met 1 pl.

31. Description de plusieurs espèces nouvelles du genre Lophyrus, met $3 \mathrm{pl}$. 
32. Beschrijving eener nieuwe soort van visschen, Polynemus multifilis, met $1 \mathrm{pl}$.

33. Over twee nieuwe soorten van visschen, Anphacanthus vulpinus en puellus met $1 \mathrm{pl}$.

34. Beschrijving eener nieuwe soort van visschen, / $e$ ristedion laticeps, met $1 \mathrm{pl}$.

35. Notice sur le genre Corvus, met 3 pl. waarvan eene 4-dubbel.

36. Description de la Pie aux Ailes brunes, fica pyrrhoptera, met $1 \mathrm{pl}$.

37. Over Elaps Jamesonii (Verslag, v. b. Zoöl. Gen. te Amsterdam, 1848.

38. Verhand. uitgeg. d. TEYLERs $3^{c}$ Genootschap XXVste stuk, bevattende een antwoord op de vraag: \$ Welke vereischten eene natuurkundige teekening moet hebben, om zoowel den natuurkundige als den kunstkenner te voldoey" (In 1847 door het Genootschap bekroond). Met 16 afb. 1849.

39. (Met C. L. Bonapante) Monographie der Loxiens. Met $54 \mathrm{pl}$. Leiden en Düsseldorf 1850.

40. Description of a new genus of Batrachians from Swanriver, Myobatrachus. (Proc. Zool. Soc. 1850). Uittreksel uit een' brief aan J. E. GraY.

41. Naamlijst der tot heden (April 1852) in de Nederlanden in den wilden staat waargenomen vogels. (Bouwstoff. v. eene fauna v. Nederl. bijeenverzameld door J. A. HerkLots.

42. Ueber das Entstehn des volkommenen Kleides der Vögel durch Verfärben und Wachsen der Federn, unabhängig von der Mauser. Sendschreiben an die am 6 Julius 1852 zu Altenburg versammelten Naturforscher. Leideı 28 Juni 1852 (Naumannia II 1852).

43. Nederlandsch Tijdschrift voor Jagtkunde 1852-54.

44. Ueber die Saat- und weisstirnigen Gänse (Anser segetum, A. albifrous et conspecies) Naumannia 1853. Kon, Acad. v. Wet. te Amsterdam 1855. 
45. Over den groei en de kleurveranderingen der vederen van de rogels (Versl. en Med. Kon. Ac. v. Wet. VI. 1857.

46. Aanteekening over de plaatsing der Muisvogels (Colius) en Musophaga in het natuurlijk stelsel (Versl. en Med. Kon. Acad. v. Wet. I, 1853.

47. Aanteekeningen over den invloed van het water op de kleuren van sommige vogels (Versl. en Med. Kon. Ac. จ. Wet. I, 1850 (rolgens aanteekening van ScHLEget in 1857).

48. Over de struisachtige Vogels (Album d. Natuur 1854).

49. Note sur le Mosasaurus (Compt. rend. Acad. sc. Paris XXXIX, 1854).

50. Ook een woordje over den Dodo (Didus ineptus) en zijne verwanten. (Versl. en Med. Kon. Acad. v. Wet. II, 1854) met pl.

51. De wolf onder de schapen (Jaarboekje van Natura Artis Magistra 1854.)

52. De zoogdieren geschetst. Eene haudleiding voor het onderwijs en tevens bestemd voor de bezoekers van diergaarden en Musea. Met 219 houtsnee-afbeeld. Amst. 1854.

53. De vogels van Nederland beschreven en afgebeeld; met 362 pl. Leiden 1854-58, 2 dln.

54. Verzeichnis der mir bekannten Arten ron Falken. (Naumannia 1855).

55. Ueber Altum's Schwan (Naumaunia 1855) met pl.

56. Ueber meine Verfärbungstheorie (Naumannia 1855).

57. Over eenige nieuwe soorten van vergiftige slangen van de Goudkust (Versl. en Med. Kon. Acad. v. Wet. III. 1855).

58. Sendschreiben an die 6 Julius 1855 in Braunschweig versammelten Ornithologen (6 Verhandelingen.)

59. De Moeflons, met 1 pl. (Jaarboekje N. A. M. 1856.)

60. De Reuzen-Kengoeroes, met 1 pl. (Jaarboekje N. A. M. 1856.) 
61. De slangen-galerï, met 1 pl. (Jaarb. N. A. M. 1856).

62. Handleiding tot de beofening der dierkunde (Natuurk. leercursus ten gebruike der Kon. Akademie voor de zee- en landmacht) 2 dl. met atlas. Breda 1857.

63. De Beden of Egyptische steenbok (Jaarb. N A. M. 1857).

64. Over eenige uitgestorven reusachtige vogels van de Mascarenhas-eilanden (een tegenhanger tot zijne geschiedenis der dodo's'; met 1 pl. (Versl. en Med. Kon. Acad. d. Wet. VII, 1858).

65. De barbarijsche Hert-Antiloop, met 1 pl. (Jaarb. N. A. M. 1858).

66. De brilbeer (Ursus ornatus) met 1 pl. (Jaarb. N. A. M. 1858).

67. Over eenige in Nederland waargenomen vreemde vogelsoorten, met 1 pl. (Jaarb. N. A. M. 1860).

68. (Met G. F. Westerman).' De 'Toerako's afgebeeld en beschreven Uitgegeven door het K. Z. G. Natura Artis Magistra 1860 (Niet in den handel).

69. Natuurlijke Historie van Nederland. De dieren van Nederland. Gewervelde Dieren. Zoogdieren, Vogels, Kruipende dieren en Visschen, met 20, 53, 11 en 21 pl. $1860-1862$.

70. Bijdrage tot de geschiedenis van de olifanten, voornamelijk van Elephas Sumatranus (Versl. en Med. Kon. Ac. v. Wet. XII, 1861).

71. Eenige woorden over de zwarte Kakatoe's en de Paradijsvogels, met $1 \mathrm{pl}$. (Jaarb. N. A. M. 1861).

72. De Maleo (Megacephalon Maleo) met 1 pl. (Jaarb. N. A. M. 1862).

73. De Kasuaris met één lel (Casuaris uniappendiculatus) met 1 pl. (Jaarb. N. A. M. 1862).

74. Muséum d'histoire naturelle des Pays-Bas. Revue méthodique et critique des collections déposées dans cet établissement I-VII, 1862-76; contenant la revue monographique des Buceros, Bucco, Cuculi, Coraces, Oiseaux de Proie, Psitta, Merops, Alcedines, Pitta, Co- 
lumbae, Struthiones, Cursores, Scolopaces, Ralli, Ciconiae, Ardeae, Ibis, Anseres, Procellariae, Lari, Sternae, Pelicani, Urinatores et Simiae.

75. De dierentuin van het Koninklijk Zoölogisch Genootschap "Natura Artis Magistra" te Amsterdam 1863 - 73 met $289 \mathrm{afb}$.

76. De vogels van Nederl.-Indië beschreven en afgebeeld: Pitta, 6 pl. met 28 afb. 1863; IJsvogels, 16 pl. met 69 afb. 1866; Valkvogels, 28 pl. met 111 afb. 1866. Haarlem, Kruseman.

77. Over de orgelvogels, met 1 pl. (Jaarb. N. A M. 1863).

78. Nederlandsch Tijdschrift voor de Dierkunde 1863-66 Bijdrage tot de kennis van het geslacht Beo (Gracula) met $1 \mathrm{pl}$.

79. Notice sur les écureuils à ventre rouge et à flancs rayés de l'Archipel Indien, met 2 pl. (1863).

80. Description d'une espèce nouvelle de Calao (Buceros Nagtglasii) met 1 pl. (1863).

81. Notice sur trois espèces inédites de pigeons du genre Ftilopus, met 1 pl. (1863).

82. Observations sur les Colombars, voisins des Treron aromatica et vernans (1863).

83. Description d'une espèce nouvelle de Calao, Buceros pulchrirostris, met 1 pl. (1863).

84. Description d'une espèce nouvelle de Faucon, Falco Bosschii, met 1 pl. (1863).

85. Description de deux espèces inédites d'Autour du sousgenre Herpetotheres, met 1 pl. (1863).

86. Notice sur une espèce nouvelle d'Oiseaux de Paradis, Paradisea calva (1865).

87. Sur un conspecies du Faisan doré, Phasianus pictus obscumus (1865).

88. Notice sur l'Astur macrourus (1865).

89. Description d'un oiseau remarquable et inconun des naturalistes, Charitornis Albertinae, met 1 pl. (1866).

90. Contributions ì la Faune de Madagasear et des îles 
avoisinantes, d'après les découvertes et observalions de MM. François Porleer, et M. D. C. van Dam (1866).

91. Notice sur les espèces du genre Megapodius habitant l'Archipel Indien (1866).

92. Notice sur le sous-genre Chalcophaps (1866).

93. Notice sur le sous-genre Tanysiptera (1866).

94. Notice sur les Cacatous blancs à huppe jaune (1866).

95. Notice sur les Nisus undiliventer et badius (1866).

96. De groote Podargus (Podargus humeralis) en de Uilgeitenmelker (Pod. Novae-Hollandiae) met 2 pl. (Jaarboekje N. A. M. 1864)

97. De knevelspreeuw (Lamprotornis Novae-Zeelandiae) met 1 pl. (Jaarb. N. A. M. 1865).

98. Het Baardwijn (Sus barbatus), met 1 pl. (Jaarb. N. A. M 1865.

99. Observations zoologiques I, II et III (Ned. Tijds. v. de Dierkunde III, 1866.)

100. Letter addressed to P. L. Sctater respecting Casuaris uniappendiculatus (Proc. Zool. Soc. 1866).

101. Communication on Mammals and Birds collected in Madagascar (Proc. Zool. Soc. 1866).

102. De Crossoptilon Mantchuricum met 1 pl (Jaarboekje N. A. M 1867).

103. De zwarthals-zwaan (Cygnus nigricollis Stephens), met 1 pl. (Jaarb. N. A. M. 1867).

104. Het rund der Soenda-eilanden (Bos Sondaicus), met 1 pl. (Jaarb, N. A. M. 1868).

105. (Met Françors P. L. Poluen). Recherches sur la faune de Madngascar. (Zoogdieren en Vogels). Leiden 1868. Met gekl. pl.

106. De groote neushoornvogel van Celebes (Buceros cassidir. $\operatorname{met} 1 \mathrm{pl}$ (Jaarb. N. A. M. 1868.)

107. Het gevlamde faisant-hoen (Euplocomus Viellotti) met 1 pl. (Jaarb. N. A. M. 1869).

108. Het aardvarken (Ocycteropus capensis) met 1 pl. (Jaarb. N. A. M. 1870). 
109. Het waterzwijn (Hydrochoerus capybara), met $1 \mathrm{pl}$. (Jaarb. N. A. M. 1870).

110. De Satijnrogel (Philorhynchus holosericeus) met 1 pl. (Jaarb. N. A. M. 1872.

111. De witte kraanrogel (Gmus leucogeranus) met 1 pl. (Jaarb. N. A. M. 1872).

112. Observations zoologiques IV et $V$ (Neal. Tijds v. d. Dierk. IV, 1873).

113. De Coscoroba (Anas coscoroba) met 1 pl. (Jaarb. N. A. M. 1873).

114. De Hemippus (Equus hemippus, Is. Geoffi.), met 1 pl. (Jaarb. N. A. M. 1873.

115. Notes from the Leyden Museum I, 1879, bevattende: mededeelingen over:

Paradoxurus Musschenbroekii.

116. Nisus rufitorques and Nisus poliocephalus.

117. On strix inexpectata.

118. On a new spucies of cuckoo from Madagascar.

119. On Strix tenebricosa arfaki.

120. On a new species of Treron from the island of Soemba (Sandalwood).

121. On Artamia bernieri.

122. On an undescribed species of Ardea (Ardea Lansbergii).

123. On Hypherpes Corallirostris, Newton.

124. On Talegullus pyrrhopigius.

125. On Gallinula Frankii.

Notes from the Leyden Museum II, 1880.

126. Hapalemur simus.

127. On Dasyurus albopuuctatus.

128. On Lepus Salac, a new African hare.

129. On an anomalous species of hare discovered in the isle of Sumatra, Lepus Netscheri.

130. On an undescribed species of blacklegged Megapode, Megapodius sanghirensis. 


\section{(95)}

131. On an undescribed bird of the Timalia-group, Malia grata.

Notes from the Leyden Museum III, 1881.

132. On the winternest of the Dwarf-mouse, Mus minutus.

133. On the zoological researsches in West-africa.

134. Entwurf eines neuen Gebäudes für die Universität zu

Leiden. Met platte gronden en vijf pl. Leiden 1881 .

Met de 29 monographieën in de Verh. o. d. Nat. Gesch. der Nederl. Overz. bezittingen, te zamen 163 grootere en kleinere werken bedragende. 


\title{
HERMANN SCHLEGEL
}

\author{
WERD OP DE DAARBIJ GENOEMDE DATA LID VAN IDE \\ NA VOLGENDE GENOOTSCHAPPEN.
}

3 Mei 1825. Corr. lid van de Naturforschende Gesellschaft des Osterlandes Altenburg).

12 Sept. 1826. Lid van de Naturforschende Gesellschaft te Leipzig.

5 Maart 1828. Corr. lid van het Genootschap ter bevordering van Nat. Historie te Groningen.

6 Juni 1832. Lid van het Prov. Utrechts Genootschap van Kunsten en Wetenschappen.

24 Juni 1833. Lid van de Naturforschende Gesellschaft te Halle.

15 Sept. 1834. Lid van de Societas Caesarea Naturae Curiosorum Mosquensia.

14 Mei 1836. Corr. lid van de Senckenbergische Naturforschende Gesellschaft te Frankfurt a/M.

29 Maart 1837. Corr. lid van het Bataafsch Genootschap te Rotterdam.

18 Mei 1839. Lid van de Holl. Maats. der Wetenschappen te Haarlem.

3 Feb. 1840. Eerelid van Natura Artis Magistra te Amsterdam.

11 Maart 1842. Corr. lid van de Reinische Naturforschènde Gesellschaft.

18 Maart 1842. Corr. lid van de Naturforschende Gesellschaft te Basel. 
24 Juli 1842. Corr. lid. van de Academie vall Wetenschappen te Turiju.

30 Dec. 1846. Corr. lid van het Naturwissenschaftl. Verein te Haarburg.

3 Mei 1847. Corr. lid van het Kon. Ned. Instituut van Wetenschappen, Letterkunde en schoonc Kunsten te Amsterdam.

22 Dec. 1851. Corr. lid van de Société royale des Sciences te Luik.

11 Feb. 1853. Corr. lid van de Natuurk. Vereeniging in N.-T.

23 Feb. 1855. Lid van de Kon. Acad. v. Wetenschappen te Amsterdam.

10 Dec. 1857. Lid van de Koninklịjke Academie te Brussel.

27 Nov. 1858. Ecrelid van de Schlesische Gesellschaft für vaterländische Cultur te Breslau.

8 Feb. 1859. Lid van de Zoological Society te Londen.

25 April 1860. Lid van het Zeeuwsch Genootschap der Wetenschappen te Middelburg.

1 Mei 1862. Buitenlaudsch lid van de Societas Linneana Londinensis.

16 Mei 1863. Eerelid vall de Zoologische Gesellschaft te Hamburg (met medaille),

23 Nov. 1865. Corr. lid der Kon. Academie van Wetenschappen te Berlijn.

20 Juli 1867. Eerelid van de Rotterdamsche Diergaarde. Lid van de Deutsche Ornitholos . lie Gesellschaft.

Corr. lid van het Bataviaasch Genootschap van Kunsten en Wetenschappen. 






$\therefore \quad \therefore \quad \cdots=$

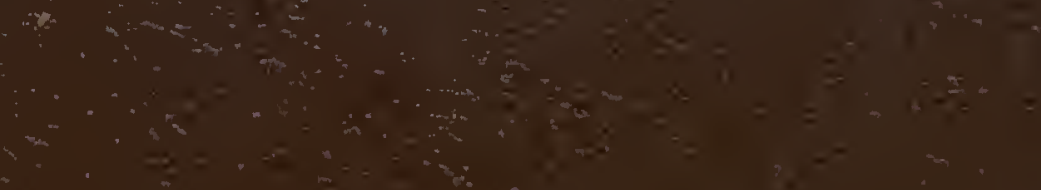

